Mapping the networks of ownership and distribution of rare books in Special Collections at the University of Auckland General Library.

by

\title{
Jo Birks
}

Submitted to the School of Information Management,

Victoria University of Wellington

in partial fulfilment of the requirements for the degree of

Master of Information Studies

June 2014 


\begin{abstract}
The extent and research potential of provenance evidence in rare books in Special Collections at the University of Auckland General Library is largely uncharted territory. This project helps fill that gap by examining the provenance evidence, such as inscriptions, bookplates and stamps, in some of those rare books to identify any networks or patterns in their ownership history and distribution.

A purposive sample of 291 pre-1851 volumes on New Zealand and Pacific-related travel and exploration was examined for provenance evidence within a qualitative framework and an historical case study design. Taking a subset of those books, which were bequeathed to the Library by Alfred Kidd (1851-1917), the project then examined other works from his bequest to further explore the scope of provenance evidence.
\end{abstract}

The project demonstrated the value of treating books as artefacts, exposing a wealth of provenance evidence and providing snapshots of the ownership and distribution histories of some volumes. Overall, 71 percent of the sample contained evidence for identifiable agents: 88 former owners, 14 booksellers, one auction house and nine book binders. The project also discussed lesser-known New Zealand book collectors who merit further study, including Alfred Kidd, Sir George Fowlds, Arthur Chappell and Allan North. Further provenance research into this collection and the provenancerelated cataloguing practices in New Zealand libraries would generate additional useful insights.

\title{
Keywords:
}

Special Collections, provenance research, New Zealand book collectors, book history, library history. 


\section{Acknowledgements}

My sincere thanks go to Dr Sydney Shep, my supervisor, who helped steer this research with her expertise, enthusiasm and support.

My thanks also to the University Librarian, Janet Copsey, and the Special Collections Manager, Stephen Innes, for granting permission to use Special Collections in this case study. Thanks also go to Stephen for sharing his knowledge on all matters NZ\&P, and to my colleague Maja Batinica for providing translations.

To Russell and to my family and friends: I don't have the room to list all of the things that I need to thank you for. Just know that I am deeply grateful. 


\section{Table of contents}

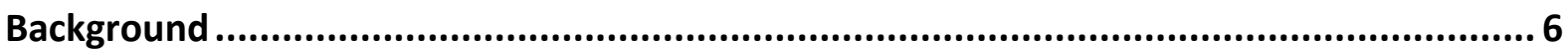

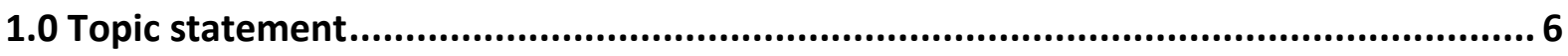

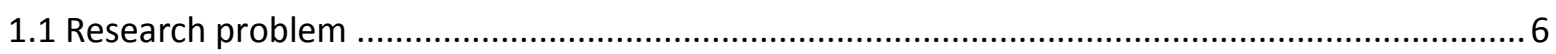

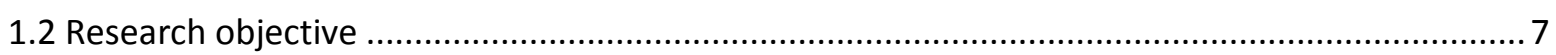

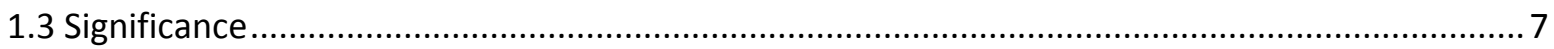

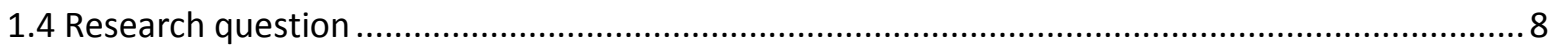

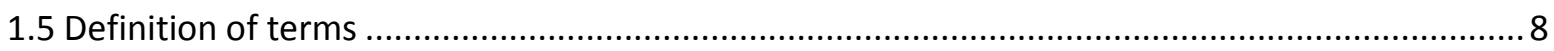

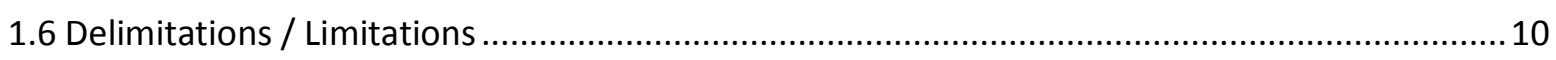

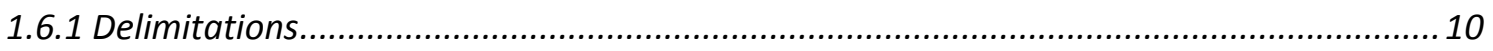

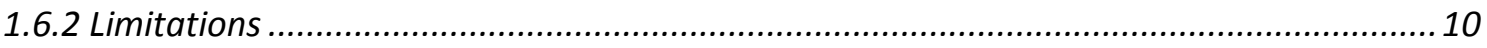

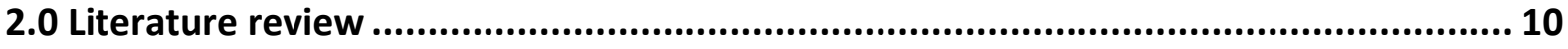

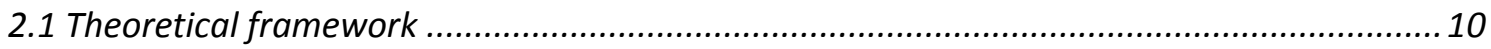

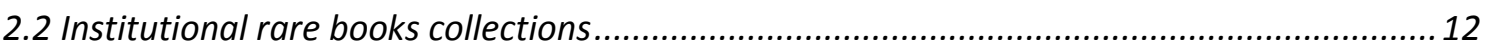

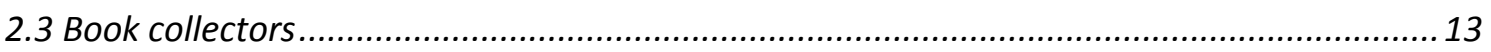

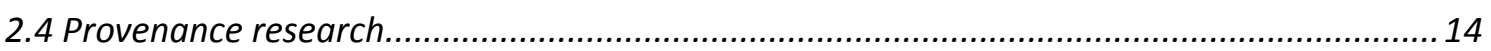

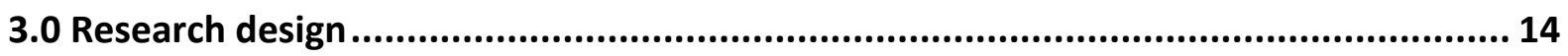

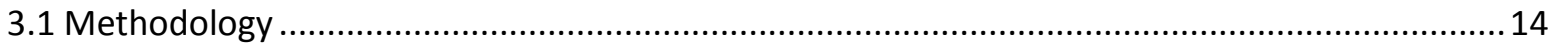

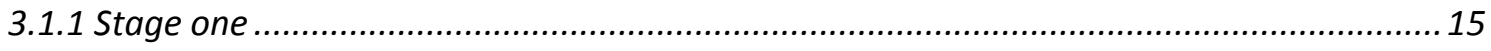

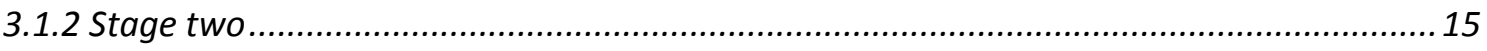

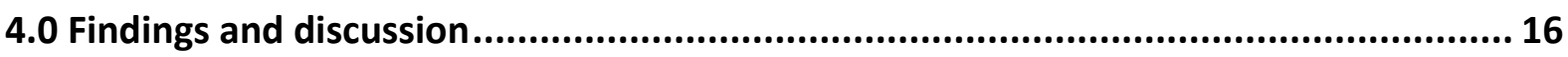

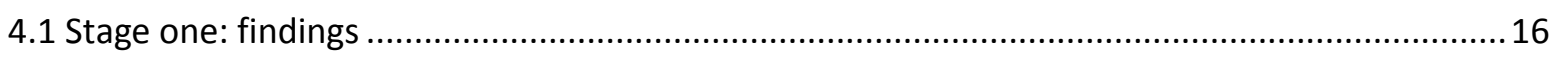

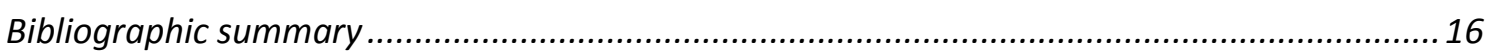

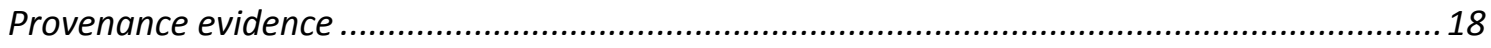

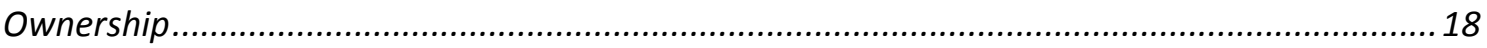

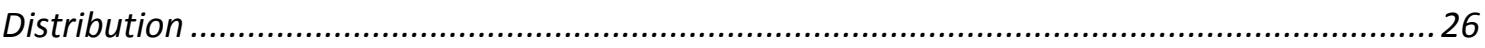

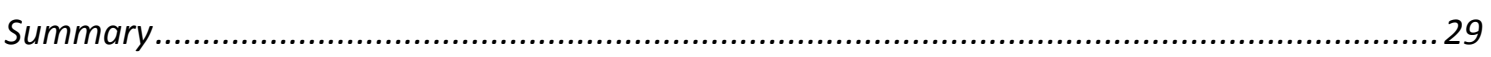

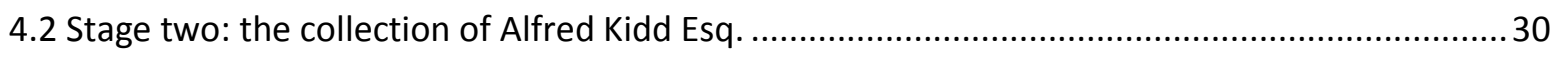

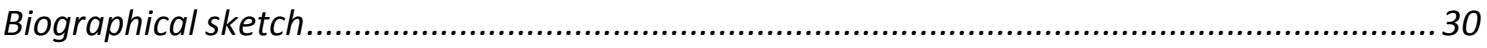

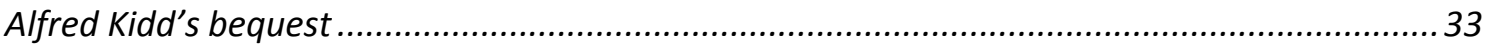

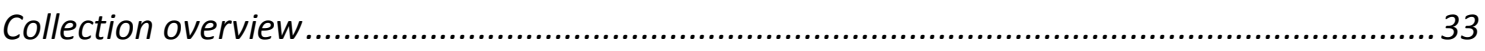

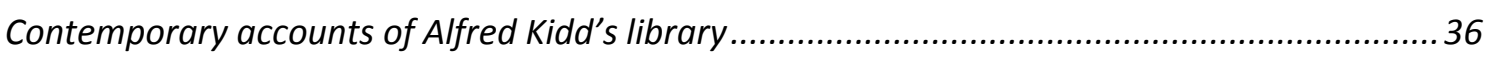

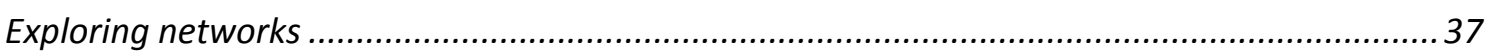

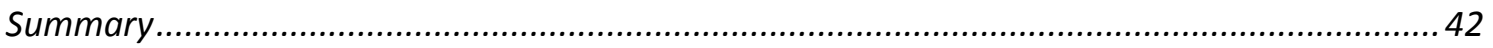

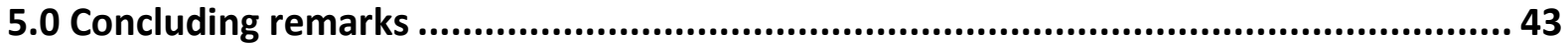

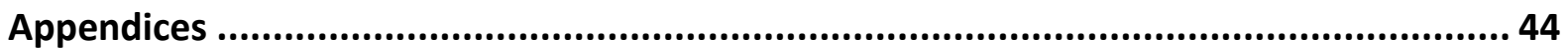


Appendix 1: Sample data collection form

Appendix 2: Provenance evidence for all identifiable agents ......................................................... 47

Appendix 3: Stage one sampled works from Alfred Kidd's bequest ........................................... 72

Appendix 4: Sample two: works with additional provenance evidence .........................................78

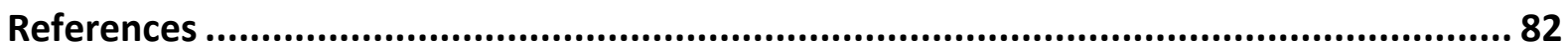




\section{Background}

A rough ink sketch on the rear free endpaper of the 1779 Dublin edition of Thomas Forrest's $A$ voyage to New Guinea... ${ }^{1}$ depicts a two-masted sailing ship heading into the wind, sails unfurled. On the facing page are pencilled inscriptions in ca. nineteenthcentury hands: "Mr Alexander Anderson, Lagan Village Belfast", "Mr Matthew Anderson" and a partly illegible ink inscription that starts out: "Mr. Wm. [Broun?], Castle Coffiled [?]". Near the front of the leather-bound volume are ink and pencil sketches of a head and two inscriptions that read: "John Stewart | Wilmont". In the twentieth century, an "A. L. Chappell" has avoided these earlier marks and pasted in a pictorial bookplate, which features a man

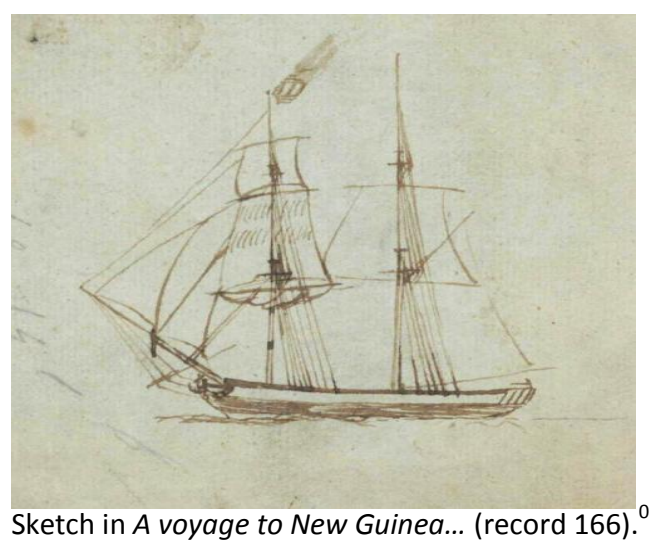
sitting on a pile of books while another paddles past in a canoe, against a backdrop of palm trees and billowing cloud.

Who were John Stewart, Alexander Anderson, William Broun [?], Matthew Anderson and A. L. Chappell? What do the marks they left behind tell us about this book's own journey over the past 235 years? And how did it reach the shelves in Special Collections at the University of Auckland General Library?

\subsection{Topic statement}

\subsection{Research problem}

The rare books in special collections in academic libraries are typically acquired over many decades through purchase, donation and bequest. Books may be purchased from antiquarian booksellers to meet academic research interests, entire private libraries or individual volumes may be gifted by collectors or their descendants, while others may be transferred from elsewhere in a library system because of their rarity, value or fragility.

An approach that views such multi-sourced collections “... through owners and their collections, rather than as one huge accumulation of authors and titles" (Pearson, p. 4) opens up numerous research avenues, including studies into former private libraries and their owners, the distribution

\footnotetext{
${ }^{0}$ All images from the sample reproduced with the permission of Special Collections.

${ }^{1}$ See Appendix 2, record 166.
} 
and reception of texts and the formation of institutional collections. This involves treating books as history and artefacts (Pearson, 2008) and entails in part an analysis of any provenance evidence between their boards. These marks of ownership can include bookplates, inscriptions, annotations and personalised bindings (Cullingford, 2011, p. 49). Donation and presentation labels also offer insights into provenance, as do booksellers' and binders' marks.

This researcher became aware of the potential extent of such provenance evidence in the rare books in Special Collections at the University of Auckland General Library while mounting a small online bookplates exhibition. An active collecting repository, Special Collections was formed in 2001 to consolidate the General Library's rare books and archival holdings. The printed collections include two large accumulations: the New Zealand Glass Case (NZ Glass Case), which houses material related to New Zealand and the Pacific (NZ\&P), and the Glass Case, which contains material related to other regions. The thousands of mostly pre-1900 volumes in these two collections have been acquired by the University since it opened in 1883 , which means that many were once owned by individuals or other institutions and potentially carry evidence of at least part of that ownership history. However, that history is obscured because, historically, provenance information was only added to the online Catalogue for some Special Collections items and it has only been routinely added for new acquisitions since 2012. Also, what little has been published about the origins of the Library's rare books collections is scattered.

\subsection{Research objective}

The research aimed to gain an insight into the provenance of a selection of rare books in the New Zealand Glass Case in Special Collections at the University of Auckland General Library to determine any networks or patterns in their ownership and in the distribution channels they took to reach the repository.

\subsection{Significance}

By exploring a sample of rare books in Special Collections through the documentation and analysis of provenance evidence and additional historical research, the research contributes to studies across multiple domains. This includes book history, “... the creation, dissemination, reception, and use of script, print, and mediacy" (Society for the History of Authorship Readership and Publishing, 2013), provenance research, the study of "... the previous ownership - of printed books and manuscripts" (Pearson, 1994, p. 83) and library history, which includes the history of institutional and public libraries (Black, 2006, pp. 446-449). It also contributes to research into private collectors, locally and internationally, as the books and their former owners originate from numerous countries. 
Further, as the provenance information will be added to Catalogue records, the project has potential value to 'real-world' researchers, including book historians examining the transmission of texts, biographers seeking insights into the intellectual influences of former owners (Lundy, 2008, p. 164), scholars tracing the formation and dispersal of private collections, and those conducting a copy census, in which multiple copies of a title are examined (Pearson, 2013).

Last, the project has significance for the General Library and Special Collections. It sheds light on a particular aspect of the Library's collection development history and the networks that contributed to its development. Also, as Lundy notes, knowledge about former ownership can make books more valuable and important to the holding institution (2008, p. 164), while the unique research value of such copy-specific information (Pearson, 2013, para. 29) may increase use of these items.

\subsection{Research question}

Using provenance evidence as the primary source, what can be learnt about the networks of ownership and distribution of a sample of pre-1851 New Zealand and Pacific-related works on travel and exploration that survive in Special Collections at the University of Auckland General Library?

\subsection{Definition of terms}

Provenance records: data records which provide "... access to evidence about a book's previous ownership ... based on physical evidence present in the book" (Overmier \& Doak, 1996, p. 91). Here, provenance records are included in Catalogue records.

Rare book: "a book of special value or interest on account of its age, limited issue, binding, or other historical factors" (Oxford English Dictionary Online, 2013).

\section{Book construction}

Boards: made from wood, paste or pulp-board, straw-board, etc, which encase a book (Barker \& Carter, 2010, p. 47).

Endpapers: double leaves added at front and rear; the outer leaves pasted to the boards' inner covers (the paste-downs), the inner leaves forming the free endpapers (Barker \& Carter, 2010, p. 91). 
Fly-leaf: “... a binder's blank additional to, and following, the free front endpaper or preceding the rear" (Barker \& Carter, 2010, p. 105).

\section{Provenance evidence}

Annotations: "remarks, notes, highlighting or commentary (generally in manuscript) on the text ..." (Association of College and Research Libraries Rare Books and Manuscripts Section, n.d.).

Armorial bindings: bindings stamped with the coat of arms, crest, or other heraldic device of the book owner (Pearson, 1994, p. 97).

Bookplates: ownership labels, usually featuring armorial or pictorial designs and sometimes the owner's name or initials, primarily printed from engravings or etchings (Pearson, 1994, p. 54). They may represent individuals or institutions.

Book labels: ownership labels, often smaller and less elaborate than bookplates, created from printers' type or engraved plates (Pearson, 1994, pp. 54, 83).

Book stamps: metal or wood stamps used to stamp an owner's name in ink (Pearson, 1994, p. 54).

Booksellers' labels, binders' tickets and stamps: stamps and labels used by booksellers and binders (Association of College and Research Libraries Rare Books and Manuscripts Section, n.d.).

Inscriptions: identifying information written by the book owner, including name, date, college, qualifications or profession, place of residence, purchase, gift or donation details (Pearson, 1994, pp. 12-16).

Markings: "... intentional or accidental marks applied manually in or on materials" (Association of College and Research Libraries Rare Books and Manuscripts Section, n.d.).

Personalised bindings: including names, initials, monograms (merged letters) and ciphers (superimposed letters) stamped or tooled on bindings (Pearson, 1994, pp. 115-119).

Bequest, donation and presentation labels: used by libraries to record bequests, gifts or presentations. 


\subsection{Delimitations / Limitations}

\subsubsection{Delimitations}

Due to its limited scale, this project did not:

- Explore book production or manufacture.

- Analyse any annotations or marginalia found in the books to gauge their reception by owners or readers.

- Seek out any privately held records or archives during the research into the identified agents.

\subsubsection{Limitations}

This research employs a case study approach, which limits the generalisability of the findings (Leedy \& Ormrod, 2013, p. 141).

\subsection{Literature review}

To help position the study, this section provides an outline of two relevant theoretical approaches and an overview of New Zealand research into the key areas of institutional rare book collections, book collectors and provenance research.

\subsection{Theoretical framework}

Numerous researchers exploring the history of the book, provenance research and library history have drawn on Adams and Barker's "new model for the study of the book" (1993). A critique of Robert Darnton's earlier communication circuit (Howsam, 2006, p. 33), the Adams and Barker model focused more on the processes than the agents involved, and placed the life-cycle events of books publication, manufacture, distribution, reception and survival - at the centre of a communication system encircled by external, influencing social forces (1993, p. 15).

Locally, Lightbourne's study into the Mangaroa Collection used the Adams and Barker model to position the findings, which she concluded encompassed "the whole gamut of the study of the book: from creation, through publication, manufacture, distribution, reception to survival" (Lightbourne, 2000, p. 139). In contrast, Major's examination of the institutionalisation of the Henry Wright collection into the Alexander Turnbull Library used the model to conceptualise the study and to situate its focus "... within the broader context" (Major, 2000, pp. 5-6). 
Of particular relevance to this research was Adams and Barker's discussion of the distribution and survival events, which offered explanations of how books reach institutional repositories such as Special Collections. As the University opened in 1883 and the books in the stage one sample were published before 1851, they were all acquired by the Library through one strand or other of the "secondary distribution system", which followed their initial distribution (Adams \& Barker, 1993, p. 25). That secondary system could have involved books being gifted, loaned, circulated via libraries or sold, through the second-hand book trade $(1993$, p. 25) or privately. For survival, Adams and Barker put forward a three-staged event: creation, initial reception and use; a period without intensive use; and a point at which a book is sought after as an object or for its content as it "... documents the age that brought it into existence and thus enters the world of collecting and scholarly research" $(1993$, p. 32). By that point, "... the tangible qualities of the book are considered as important as its content" $(1993$, p. 36). Survival in an institutional collection need not spell the end of a book's life-cycle, however, as librarians can "... ensure that effective distribution, in a new sense, continues" (1993, p. 27).

Rukavina's rhizomorphic social network concept was also used to help conceptualise the networks in ownership and distribution of the sampled books. In her study of Edward Petherick and his bookselling networks across Britain, Australia, New Zealand and North America in the late nineteenth century, Rukavina argued that both the Adams and Barker and Darnton models were too linear and one-directional (2010, pp. 9, 19-20). Instead, she put forward a concept of rhizomorphic social networks in print production and distribution which used three principles from French theorists Deleuze and Gauttari: connection, multiplicity and rupture (Rukavina, 2010, p. 25). She also adopted their definition of 'agent' to mean a "... 'node within a network', connecting or referencing other nodes ..." and which could refer to books or people (2010, pp. 24-25). This increased the scope of possible interactions between agents while not restricting them to a '... circuit of set events or possible responses" (2010, pp. 26-27). Connections could embrace "... a chaotic disorder where any book trade agent can potentially engage or 'meet' another agent" (p. 25). Multiplicity allowed multi-directional growth and a "... diversity of connections" (p. 29). Rupture avoided predetermined paths and hierarchy, meaning that, "As it expands or changes, the social network, because it can both break and also start up again, creates new networks or re-establishes old ones" (p. 30).

In this project, Rukavina's concept was applied to the secondary distribution networks that Adams and Barker discussed and through which all of the sampled books have travelled. Similarly, connections, multiplicity and rupture were applied to books which have reached the later survival 
stages of their life-cycles (Adams \& Barker, p. 32), while "agent" was used to include owners, second-hand booksellers and libraries.

\subsection{Institutional rare books collections}

A comprehensive history of the origins of the country's rare book collections has yet to be written (Hughes, 2013, p. 22; Elliott, 1982, p. 175). However, various strands have been teased out in overlapping studies on particular libraries and on private collectors whose libraries found new lives in institutional collections. The library histories included Barrowman on the Alexander Turnbull Library (1995) and Martin on the Parliamentary Library (2008). One of the common elements identified in the early development of those libraries was the importance of book donations and bequests and secondary distribution channels to facilitate purchases (Martin, 2008, pp. 30-35; Barrowman, 1995, pp, 42-43, 49). The role of benefactors was also raised in Elliott's selective survey of how pre-1801 imprints were acquired by particular institutional libraries (1982). Elliott observed that by gifting their collections to the public, Sir George Grey and Alexander Turnbull helped create a climate that spurred others to similar acts of generosity (Elliott, 1982, p. 175-178). Of the universities enriched by private benefactors, Elliott noted that the University of Otago was most successful, securing the significant collections of Thomas Hocken and the de Beer family (1982, p. 181). Some books from early institutions also found new institutional homes, including Canterbury University's acquisition of material from Christ's College (Elliott, 1982, p. 180). Lacking large-scale donations of pre-1801 imprints, Elliott noted that the universities of Auckland and Victoria had acquired theirs through "direct purchase or, more commonly, as a result of miscellaneous donation" $(1982,179)$.

Elliott's observation about "miscellaneous" donations aligned with Johnson's comment about early donations in her brief history of the University of Auckland Library (1988, p. 2). Founded in 1883, the-then Auckland University College (AUC), was a "starveling institution, lacking any of the generous endowments bestowed on other Universities" (Johnson, 1988, p. 1). She also noted some substantial gifts, including 1300 books bequeathed in 1894 by Professor Charles Alexander Maclean Pond (p. 2) and a "large number" of books presented in 1925 by the parliamentarian and AUC Council president Sir George Fowlds (1988, p. 6), among others.

The literature also included discussions about institutional library acquisition policies and their deliberate and "judicious purchasing" (Elliott, p. 183) to serve the interests of their patrons. There is room, however, for more specific research into the extent and impact of collection developmentdriven purchasing of rare books by local institutions. 


\subsection{Book collectors}

A sizeable body of literature exists on New Zealand book collectors, in particular those whose libraries have been institutionalised, including Kerr on F.W. Reed (2002) and Sir George Grey (2006), McCormick on Alexander Turnbull (1974), Wevers on the Beetham family's Brancepeth Station Library (2010) and Major on Henry Wright (2000). A handful of works also include roll calls of the better-known bibliophiles (Ross, 1997; Traue, 1991).

Less has been written about collectors whose libraries were dispersed or remain privately owned. A recent exception was Hughes' study into colonial printer, editor and reviewer Robert Coupland Harding (1849-1916), whose library was sold by auction in 1920 (Hughes, 2013). Hughes examined Harding's book collecting practice and the wider field around the turn of the twentieth century through an analysis of the New Zealand section of his library auction catalogue, his correspondence with contemporaries and three case studies using books as agents (2013, p. 2). Through this, Hughes identified numerous social networks in which Harding was active, including book collecting circles (2013, p. 56), membership of philosophical and scientific institutes (2013, p. 78-79) and with book industry agents such as auctioneers and booksellers $(2013$, p. 27,58$)$

Categorising collectors was another theme of the local literature. The term "colonial collector" was used to describe collectors who were interested in acquiring and preserving all material published in and about the colony (Traue, 1991, p. 31; Ross, 1997, p. 202). Thomas Hocken was the "prime exemplar" (Ross, p. 202) and although this also partly described Grey and Turnbull, their wider pursuits and greater purchasing power also put them in the traditional "connoisseur category" with their focus "on choice works and on rarities" such as illustrated manuscripts and incunables (Traue, 1991, p. 31). Hughes more recently offered a new taxonomy of collectors: historian-collector, hoarder-collector, merchant-collector, broker-collector and critic-collector (Hughes, 2013, p. 36).

Local studies into collectors also encompassed the various distribution channels and networks they used to assemble their libraries, including local and international booksellers and agents, consignment sales and auctions (Kerr, 2002; Kerr, 2006; McCormick, 1974 and Hughes, 2013). Less formal channels included purchases or exchanges between collectors (Kerr, 2006, p. 224-225; Hughes, 2013, p. 56-57) and gifts and presentation copies from authors and publishers (Kerr, 2006, p. 243-245). Those networks and channels helped underpin a vigorous local book collecting community. Some of these collectors went on to enrich the country's institutional collections through "bequest, gift, or sale; or indirectly by contributing to the pool of books available in New 
Zealand" (Traue, 1991, p. 28). It was from this pool that many libraries have made their "judicious purchases".

\subsection{Provenance research}

Provenance research was embedded within numerous local studies, including Kerr's biobibliographical study of Sir George Grey, which entailed a physical examination of his collections (Kerr, 2006, pp. 16-17). Another study which extensively used provenance evidence was Lightbourne's investigation into the history and significance of the Mangaroa Collection (2000). To expose the collection's research potential (2000, p. 1), Lightbourne examined a sample of mostly nineteenthcentury monographs for provenance marks, subscription lists and their typography, title pages and illustrations, and those printed by private presses (pp. 67-139). Based on that evidence and historical research, she revealed the collection's research value, its miscellaneous origins and the various networks at play. Important familial connections were shown through eighteenth- and nineteenthcentury bookplates, armorial bindings and inscriptions (p. 77). Presentation labels revealed links between the former owners and the institution (2000, p. 69-81), while binders' tickets and booksellers' labels highlighted book production and distribution networks (2000, pp. 9-13, 40-47).

\subsection{Research design}

The project used a qualitative research strategy and an historical case study design, as is common in the book and library history fields and in provenance research (Lundy, 2008; Lightbourne, 2000; Major, 2000). This qualitative approach was best suited to capture, describe, interpret and gain insights into complex phenomena in a 'real-world' setting (Leedy \& Ormrod, pp. 139-140). In this instance, the historical case study encompassed personal and organisational facets (Gorman \& Clayton, 2005, pp. 47, 50) as it was an in-depth investigation in a single setting into the historic actions of individuals and institutions.

\subsection{Methodology}

A two-staged research approach was adopted. The first stage involved capturing the provenance evidence from the sampled works and undertaking preliminary data analysis and research. That information was used to determine the focus and data collection in the second stage, a common practice in case studies (Leedy \& Ormrod, 2013, p. 142). 


\subsubsection{Stage one}

A purposive sampling approach was used to generate the most information about the research topic (Leedy \& Ormrod, 2013, p. 152). From a population of nearly 14,000 printed items in the NZ Glass Case, the purposive sample comprised New Zealand and Pacific-related travel and exploration titles published before 1851, catalogued between 910 and 919.99 inclusive under the Dewey classification system (Online Computer Library Center, 2013). This narrow slice reflected the small-scale nature of the project, while the subject recognised the collection strength of the Library and its ongoing commitment to acquire such material to support the University's teaching and research. The age of the books also increased the likelihood of extant provenance evidence.

The 291 physical items that fell within the sample were identified using a catalogue-generated list, backed by a shelf-check within the call number range to detect any omissions or misidentifications. Each item was examined for provenance evidence, with particular attention paid to the pastedowns and preliminary and rear pages, where such marks are often encountered. Any annotations or marginalia in the text block were summarised, not transcribed. As the provenance evidence was captured and analysed, Pearson's caution about the problems facing provenance researchers was kept in mind: some owners leave no traces, marks may be lost when boards and pastedowns are discarded during rebinding, inscriptions may be excised, illegible or of uncertain origin or meaning, while bookplates may be mutilated or difficult to identify (1994, pp. 3-9).

The bibliographic details and research data were entered into an Excel spreadsheet. Where applicable, controlled vocabulary terms for provenance evidence were used (Association of College and Research Libraries Rare Books and Manuscripts Section, n.d.) ${ }^{2}$. The data were analysed manually and researched to gain an overall understanding of the quantity and types of provenance evidence and, where possible, to identify the former owners, booksellers and bookbinders. Various sources were used to help with that identification, including Library records, biographical dictionaries, digitised newspapers, primary records and provenance-related resources.

\subsubsection{Stage two}

The stage two purposive sample took as a starting point the 39 works of Alfred Kidd's bequest from the stage one sample and explored a further 211 works from his bequest. The same data analysis strategies were employed while the historical research drew on similar sources.

\footnotetext{
${ }^{2}$ See Appendix 1 for a sample data collection form.
} 


\subsection{Findings and discussion}

The project findings are presented in two sections: the first discusses the evidence of networks in ownership and distribution from the overall data; the second explores same networks from a selection of books from Alfred Kidd's collection.

\subsection{Stage one: findings}

\section{Bibliographic summary}

The sample was made up of single to six-volume titles, with up to five copies held for some. It totalled 291 physical items made up of 161 single and multi-volume titles published before 1851 on New Zealand and Pacific-related travel and exploration. Multiple copies of some titles took the total number of sampled works to $208^{3}$. The works were published between 1739 and 1850 inclusive, with 23 percent $^{4}$ ( 48 works) published up to 1799 inclusive and 77 percent (160 works) published between 1800 and 1850 inclusive. Nearly three-quarters (73 percent) were published in England, with the rest from nine other countries. Some 179 works were in English, 25 in French, two in German, and one each in Spanish and Dutch.

\section{Number of works by publication location}

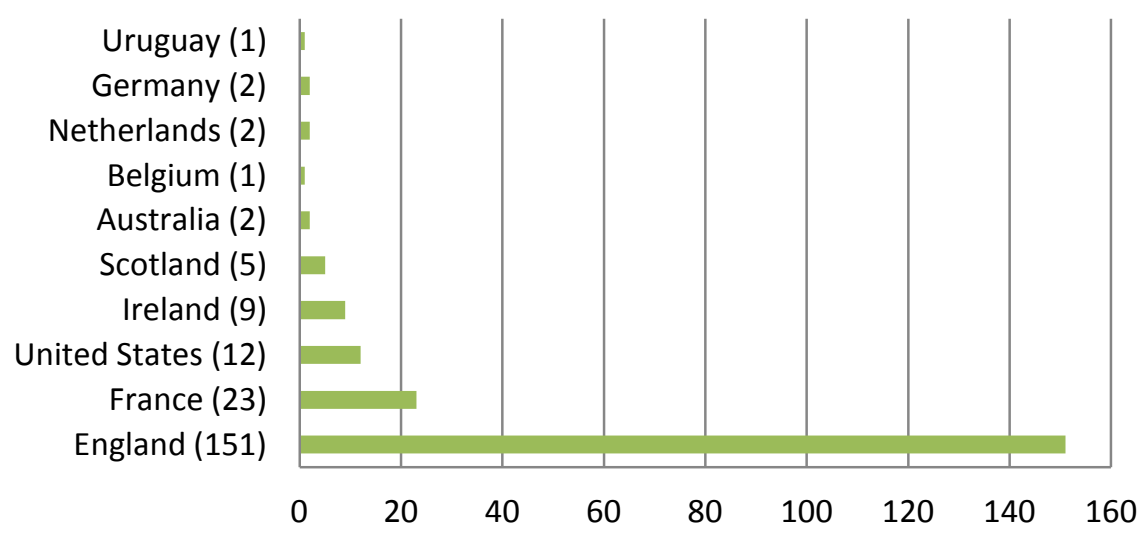

The sample included some of the major eighteenth-century monographs on European travel and exploration in the Pacific, such as the official narratives of the three voyages of James Cook: John Hawkesworth's Account of the voyages undertaken by the order of His Present Majesty for making discoveries in the Southern Hemisphere... (1773, London, records 14-16), Cook's A voyage towards

\footnotetext{
3 "Title" describes a discrete bibliographic entity whereas "works" may include multiple copies of a title.

${ }^{4}$ Percentages have been rounded up or down to the nearest whole percentage point.
} 
the South Pole... (1777, London, records 37-38) and A voyage to the Pacific Ocean... (1784, London, records 27-30).

The French explorations included Charles Fleurieu's Decouvertes des Francois, en 1768 \& 1769... (1790, Paris, record 49), Louis-Antoine de Bougainville's Voyage autour du monde par la frigate du roi La boudeuse... (1771, Paris, record 8) and La Perouse's Voyage round the world... (1799, London, records 56-58). The nineteenth-century explorations included Otto von Kotzebue's A voyage of discovery, into the South Sea and Beering's Straits... (1821, London, records 99-101) and Sir James Ross's A voyage of discovery and research in the southern and Antarctic regions... (1847, London, records 290-291). The staples of early travel in and around New Zealand included John Savage's Some account of New Zealand... (1807, London, record 244) and Augustus Earle's Narrative of a nine

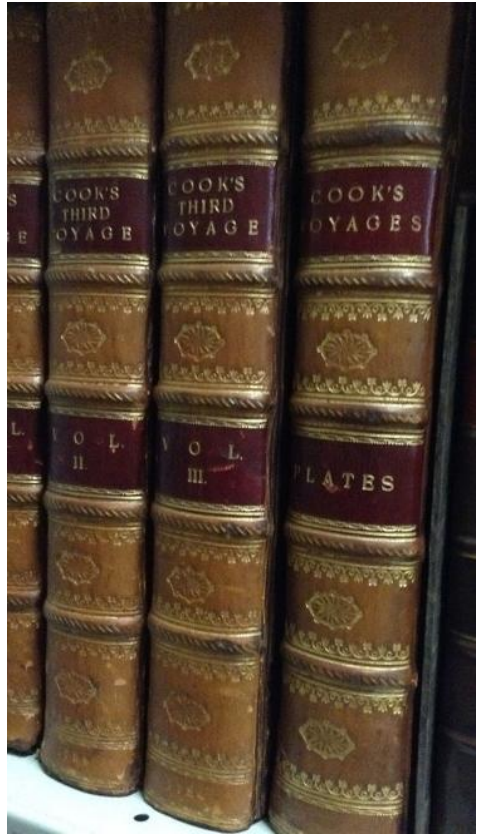
Cook's 1784 A voyage to the Pacific Ocean... (records 23-26). months' residence in New Zealand... (1832, London, record 206).

In format, they ranged from the large folios of George Angas's South Australia illustrated and The New Zealanders (1847, London, records 177-179), with their superb hand-coloured plates, to the utilitarian octavos of colonial guides such as Edward Wakefield's Handbook for New Zealand... (1848, London, record 248).

The bindings included contemporary eighteenth-century full leather with lettering pieces, marbled edges and gold tooling, nineteenth-century half-leather and marbled boards, original paper wrappers or cloth boards and twentieth-century Library rebinds. 


\section{Provenance evidence}

Seventy-one percent of the sample (147 works) contained evidence that represented identifiable owners, booksellers, auctioneers and binders. ${ }^{5}$ Of the former owners, 77 were private individuals and 11 were institutions. There were marks for 14 identifiable booksellers, one auctioneer and nine binders. Of those 147 works, 94 had contemporary or near contemporary bindings, the others had twentieth century bindings. Many works contained anonymous codes, prices and other markings but these could not be ascribed to particular individuals or agents.

\section{Ownership}

Overall, 137 works (66 percent) contained evidence for at least one former owner, while a handful contained markings for up to four. Bequest, presentation and gift labels were the most common mark that indicated previous ownership ${ }^{6}$, with 96 instances recorded for nine benefactors (including multiple counts for the same person or institution when they owned more than one work or marked each volume in a multi-volume set). Handwritten inscriptions - names, and sometimes dates and locations - were the next most common marks for individuals, followed by ink or blind stamps, pictorial and armorial bookplates, and labels. The earliest dated inscription was for a William Carlen, who signed his name and the date " 1 August 1784 " in all three volumes of that year's abridged edition of Cook's A voyage to the Pacific Ocean... (1784, London, records 27-30), suggesting he was the first owner. Stamps were the most common marks for institutions.

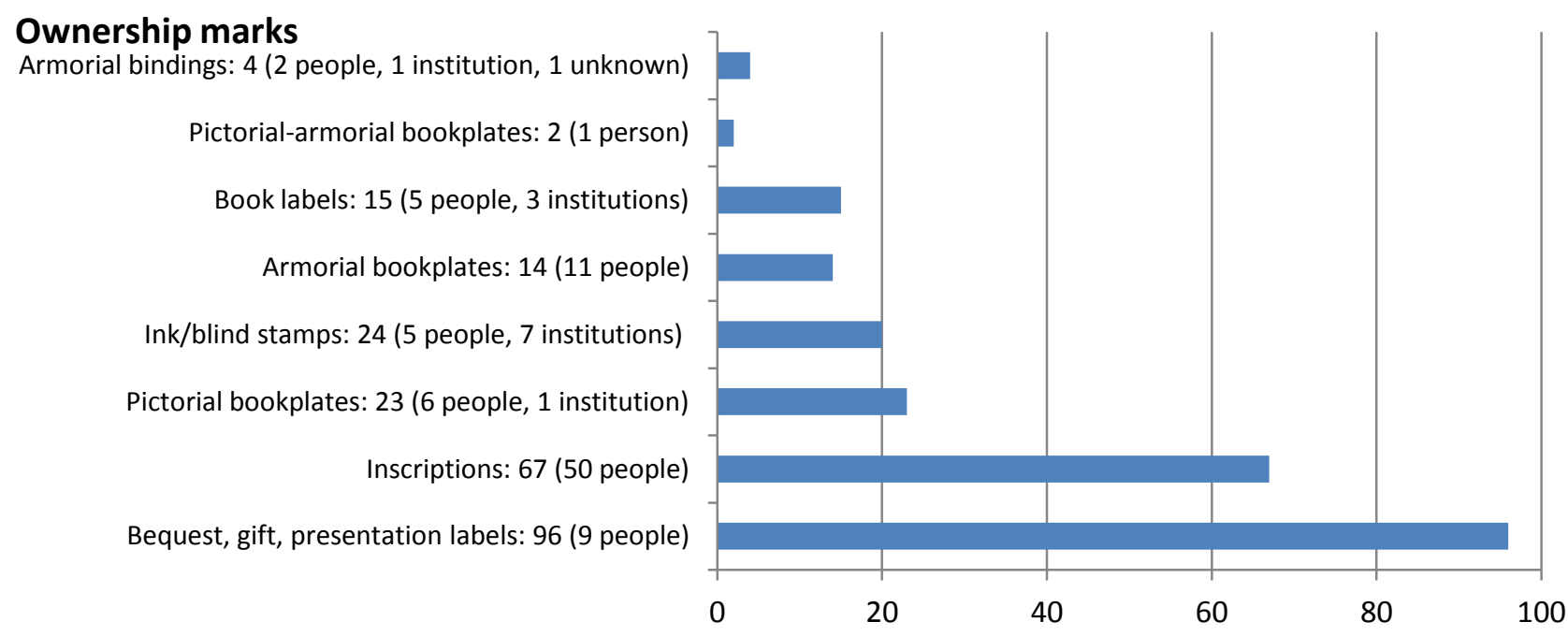

\footnotetext{
${ }^{5}$ The agents who left enough information to pin-point their location have been mapped to gain an overall picture of their geographic spread. The maps are in the following discussion. Brief biographical details are provided for some in Appendix 2 . ${ }^{6}$ These were categorised by donor, not recipient.
} 

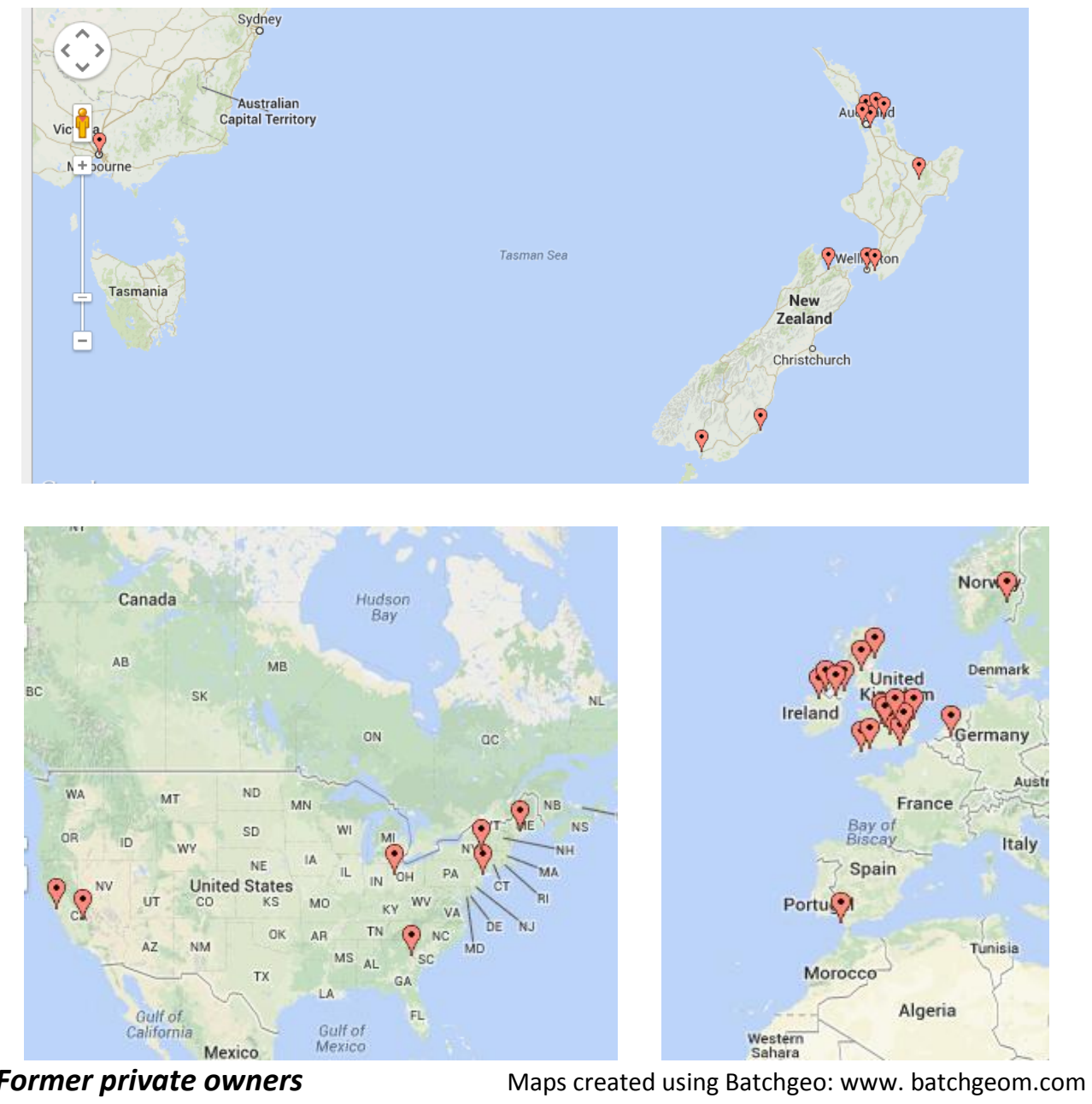

The former private owners who could be located geographically from the evidence were clustered around the expected nodes of England, Europe and New Zealand. There was only one Australian owner and seven from the United States. The 22 Europeans were the earlier owners of the books and were active particularly in the early to late-nineteenth century, reflecting the age and origins of the books and their first distribution in that region. The 11 New Zealand collectors made up the next major grouping and reflected the colonial-collecting tradition around the late nineteenth to midtwentieth century that was identified in the local literature. Most of the former United States owners were active from the early twentieth-century onwards.

There were three exceptions to these geographic concentrations. In 1854, the otherwise unidentified "A.P" of Cadiz, Spain, inscribed a copy of Hombron's Aventures les plus curieuses des voyageurs, coup d'oeil autour du monde... to "Maria Carrera y Ravina/Ravira [?] (1847, Paris, record 54). The Norwegian-born Pacific bibliographer Bjarne Kroepelien accounted for the Oslo pin (record 124), while the twentieth-century Dutch collector A.P.M. de Kluys of Tilburg once owned the only Dutch-language title in the sample, F.L. Walther's Natuur en aardrijkskundige beschrijving der Vriendlijke Eilanden in de groote Zuidzee, volgens de Nieuwste ontdekkingen... (1787, Amsterdam, record 277). 
The contribution that benefactors made in the early decades of the Library's establishment and in the early development of this portion of the Library's NZ\&P rare books collection was highlighted through the presence of the 96 bequest, presentation and gift labels. That evidence is extant because the Library took care to acknowledge such generosity in that way, whereas there was a relative lack of evidence that specifically identified booksellers. That imbalance of evidence masked the Library's extensive purchasing in this area over the decades and underplayed the role of booksellers in the distribution of many of the sampled works.

However, the role of benefactors was still important in the collection's early development and research into those former owners revealed an interesting web of connections with the institution and, in some cases, with each other. It also provided snapshots of some lesser-known local collectors.

The earliest bequest in the sample was the two-volume Captain Cook's voyages round the world... (1790, Newcastle, records 11-12), which was among 580 volumes spanning many subjects that Auckland University College Library (AUCL) acquired from James Leask Sinclair in 1895 (Auckland University College, 1919, p. 19). Sinclair, born in Scotland in 1828, emigrated to New Zealand in 1865 and worked as a journalist on the Southern Cross newspaper and as a teacher. His daughter, Mary Sinclair, graduated M.A. from Auckland in 1890 (Tee, 1980/81, p. 377).

Two of the key benefactors identified in the sample were Alfred Kidd (1851-1917), an Auckland mayor and Liberal Member of the House of Representatives (MHR), whose NZ\&P collection was bequeathed to the College in 1918, and Sir George Fowlds (1860-1934), also a Liberal MHR, who presented hundreds of volumes to the Library in 1925 . The other benefactors who belonged to the same collecting generation as Kidd and Fowlds, and straddled the nineteenth and twentieth century were Auckland businessman James Cuthbertson Entrican (1865-1951) and Edward Earle Vaile (18691956), an Auckland real estate agent, farmer and philanthropist (Nightingale, 1996). Vaile presented books in the 1930 s and $1950 s^{7}$, Entrican in the early $1950 s^{8}$ (Johnson, 1988, p. 17).

As well as their shared interests in books, these men were part of overlapping social networks. All were active in Auckland's business community and in various social and civic capacities. They were members of the leading scientific institutions of the day. Kidd, Fowlds, Entrican and Vaile were all members of the Auckland Institute, an affiliate of the New Zealand Institute, the forerunner of the

\footnotetext{
${ }^{7}$ Vaile records: 168-169, 250A.

${ }^{8}$ Entrican records: 10, 149.
} 
Royal Society of New Zealand (New Zealand Institute, 1906, pp. 558-559; 1916, p. 552). Fowlds, Entrican and Vaile were also members of the Polynesian Society (Polynesian Society, 1927, pp. 9192, 95). Those with the closest connections to the University were Sir George Fowlds, an AUC Council member for 17 years and president for 13 years, and Alfred Kidd, who was on the College Council for two years (Sinclair \& McNaughton, 1983, pp. 305-306).

Their philanthropy can be seen within the context of their times, during which private collectors were enriching other local institutions, including Thomas Hocken's gift to the University of Otago in 1908, although announced in 1897, historian and Liberal politician Robert McNab's gift to Dunedin Public Library in 1913, Alexander Turnbull's in 1918 (Barrowman, 1995, pp. 24-25) and John Macmillan Brown's to the University of Canterbury in 1935 (Jones \& Matthews, 2011, p. 12).

The donations to the AUC Library were welcome as it was set up without the nucleus collection or subscription fund that some of its counterparts enjoyed and was dubbed the "Cinderella of University Libraries in New Zealand" (Minchin, 1941, October, p. 54); the Library was to endure inadequate funding for decades (Johnson, 1988). Such gifts were acknowledged each year in the College Calendars, many of which also attracted news coverage. After Fowlds' presentation in 1925, the Auckland Star wrote, "Mr Fowlds' example, we hope, will be followed by other citizens who are fortunate enough to possess good libraries" ("The College Library," 1925, p. 6).

Benefactors were still being acknowledged in the 1960s, with Olive Johnson, the Library's acquisitions librarian commenting, "However wealthy we may, in some unimaginable future, become, there will never be a time when the generous donor loses his or her importance to us" (Johnson, 1962, April, p. 8). The last major gift of NZ\&P works to the Library was that in 1968 by the Urewera-based GP Allan North (1908-1982) and his wife, Jess North (1913-1997), a nurse (The University of Auckland Library, 1968, p. 1). Nine works ${ }^{9}$ in the sample came from Dr North, who was from a later generation of local collectors than the previously discussed benefactors. It was through the Norths' association with anthropologist Sir Sidney Mead, then of the University's Anthropology Department $(1968$, p. 1), that the Library acquired the collection of around 700 volumes.

\footnotetext{
${ }^{9}$ North records: 175, 193, 198, 203, 206, 230-231, 237-238, 247, 258.
} 


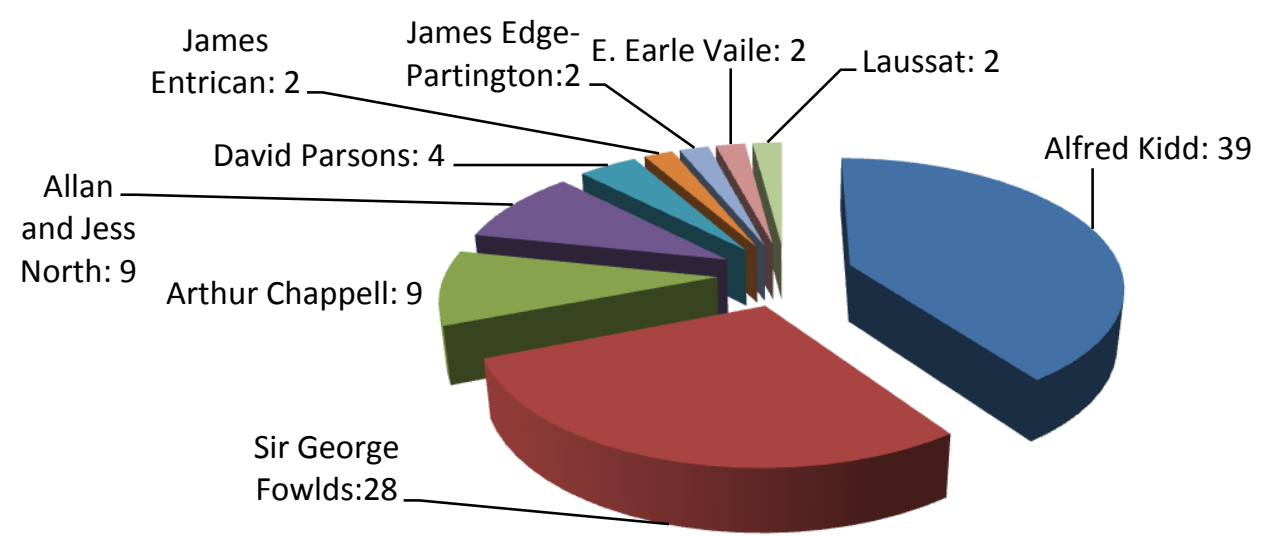

\section{Former owners of multiple works in the sample}

The other instances where multiple works in the sample came from the shelves of a single collector reflected the Library's long-standing collection development policy and, in particular, its purchases from antiquarian booksellers. Some also illustrated the international reach of the second-hand book trade that resulted in dispersed libraries finding new homes in far-flung private and institutional collections.

The nine works ${ }^{10}$ from the library of local journalist and bookman Arthur Lewis Chappell (1887-1965) were among around 400 NZ\&P titles purchased privately in 1965 (The University of Auckland Library, 1966, p. 2). Two works ${ }^{11}$ once owned by James Edge Partington (1854-1930), an English ethnologist, author, collector and member of New Zealand's Polynesian Society, were purchased from booksellers. One, Peter Bays' Narrative of the wreck of the Minerva... (1831, Cambridge, record 109), also contained the pictorial bookplate of Nancye Kent Perry (1918-2011), an Australian entomologist and artist ("Perry, Nancye Enid Kent (1918-2011),"), who penned a 1973 acquisition date on her bookplate. That left many decades in which the book's location remained unknown before it was in Partington's hands and until it reached Perry. However, that partial ownership history is consistent with the often fragmentary nature of such evidence; it also fits with Adams and Barker's comment that books are not continuously on the move and that distribution “... includes more than simply getting a book or text from one person to another. It also includes the extent, in time and space, to which that process takes place" (1993, pp. 26-27). Adams and Barker also wrote of external forces that "... send books off on their next journey to other homes, sometimes through the second-hand and antiquarian market, to other collectors, some come to rest again in an institutional library, where, by now, they may be treated as treasures and kept in a rare-book room" (p. 26).

\footnotetext{
${ }^{10}$ Chappell records: 72-73, 77-78, 102-104, 143, 155, 164, 166, 286, 287

${ }^{11}$ Edge-Partington records: 109, 180.
} 
The four works ${ }^{12}$ that once belonged to David Parsons, a collector in the United States, were part of his Pacific voyaging collection that was offered for sale in 2005 through Hordern House, the Sydneybased antiquarian booksellers (Hordern House, 2005). As well as the R.D.P. label signifying it was from the Parsons collection, one of the works (records 146-147) also contained an anonymous nineteenth-century armorial bookplate with the motto, "He plaa diu t'ayudy", which may represent a nineteenth century member of the French Laussat family. This same bookplate was found in another sampled work that was purchased from a different bookseller, showing Rukavina's concepts of multiplicity and rupture at work as the dispersal of that collection resulted in quite different trajectories for its books.

Ross observed that book collecting served the writing and professional interests of some collectors (1997, p. 202). Former owners from the sample for whom that would have applied included the author and historian Eric Hall McCormick (1906-1995). McCormick, who held various posts at the University of Auckland, bequeathed to the Library his copy of John Ward's New Zealand: Nelson, the latest settlement... (1842, London, record 252). He authored numerous books, including on New Zealand history and Pacific exploration, and the collectors Alexander Turnbull (1974) and Thomas Hocken (1961) (McEldowney, 2000). Historian and parliamentarian Robert McNab was another example. In a copy of E.J. Wakefield's Hand-book for New Zealand... (1848, London, record 249), McNab inscribed in ink: Robert McNab | Invercargill, N.Z. | 1897. McNab and Sir George Fowlds were in parliament together for three terms, which would explain how Sir George acquired the volume, which he later presented to the Library. It would also explain its absence from the McNab collection, which went to the Dunedin Public Library in 1913 (Barrowman, 1995, p. 24). Former overseas owners that also fit that mould included the previously mentioned Norwegian bibliographer Bjarne Kroepelien (1890-1966), whose pictorial bookplate was found in Jared Sparks' Travels and adventures of John Ledyard (1834, London, record 124), and English ethnographer James Edge-Partington.

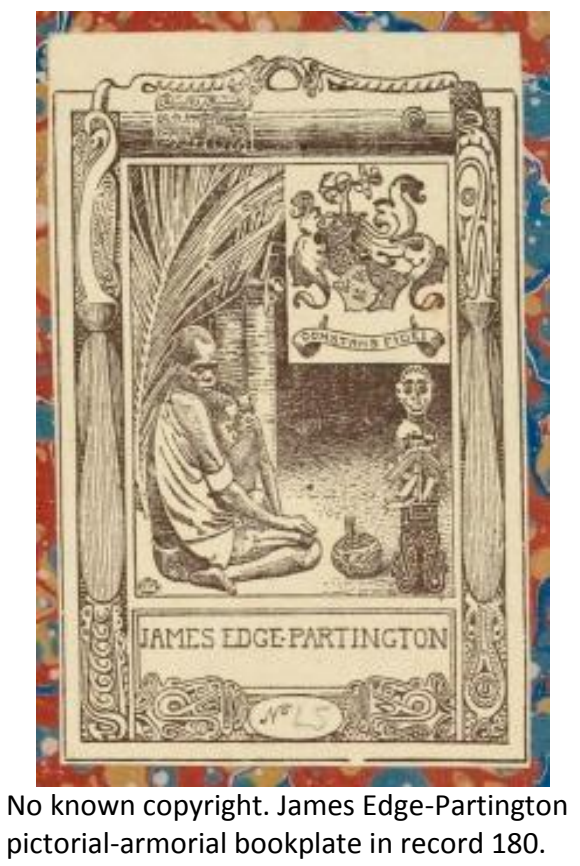

\footnotetext{
${ }^{12}$ Parsons records: 135-139, 142, 146-147, 152-153.
} 
Other examples of exchanges, gifts and presentation copies were found. An ink inscription on paper pasted to the flyleaf of the second edition of Voyages and travels round the world, by Daniel Tyerman and George Bennet... (1841, London, record 64) read: "To The Revd. William Henry | from the Director | and with the cordial regards | of his obliged friend | George Bennet | Mission House | Jany 25 1841". There were two other inscriptions in the volume, a ca. nineteenth-century inscription for "P.H. Henry" and one ca. twentieth-century that read: "Ronald M. Arndell". George Bennet, of the London Missionary Society (LMS), was one of the journal authors from which the book was compiled by James Montgomery. William Henry may have been the missionary on board the LMS vessel the Duff, the voyage of which was recounted in Wilson's $A$ missionary voyage to the southern Pacific ocean: performed in the years 1796-1797, 1798... (1799, London, records 265-266). In January 1841, Bennet was living in

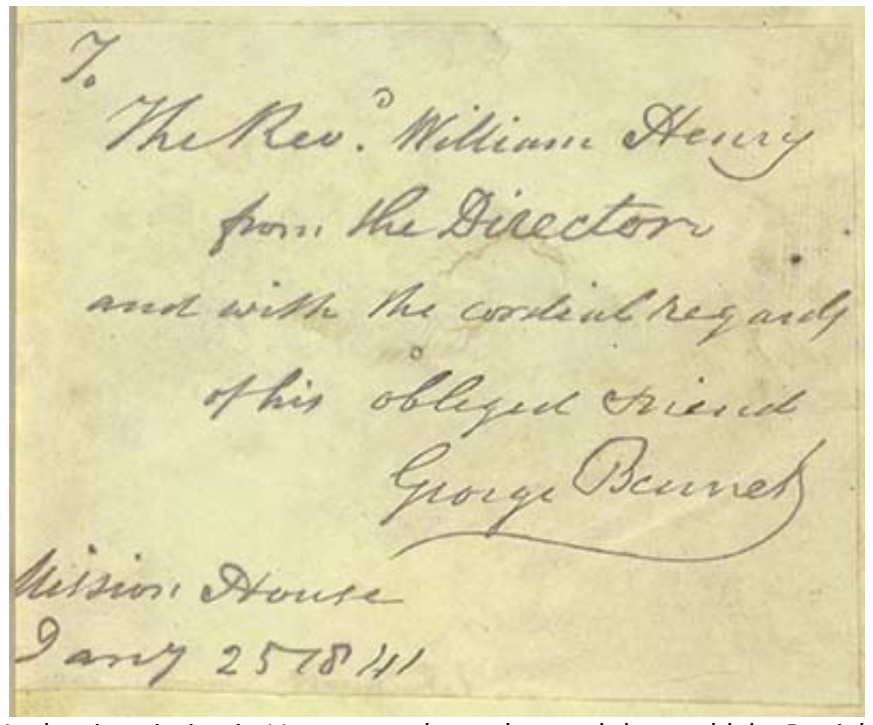

Author inscription in Voyages and travels round the world, by Daniel Tyerman and George Bennet... (record 64).

London where he died later that year ("Death of George Bennet, Esq.," 1842, p. 14), while William Henry (born 1770) was in Tahiti where he spent many years as a missionary. Henry died in Sydney in 1859 (Gunson, 1966). P.H. Henry may be William Henry's son, Philip Hitoti Henry (1829-1909) (Gunson, 1970, p. 51).

Tracing the ownership histories of duplicates in the sample highlighted the multiplicity of paths the books took to reach Special Collections. They also showed the popularity of some titles among New Zealand's book collectors and their research value to the University, which meant that multiple copies of different editions remain on the Library's shelves. For example, there were multiple, wellthumbed copies of two editions of Richard Cruise's Journal of a ten months' residence in New Zealand. An 1824 edition of Cruise's Journal... (1824, London, record 198) had an inscription for "F.J. Halse" and, in the same hand, "Sold by Bethune \& Co | 23 March 1934 | f4.10 | [illegible] 1949 up to [illegible] | at Bethune". This was Frederick James Halse (1863-1936), a Wellington cartographer for the Department of Lands and Surveys, who also compiled a chart of wrecks around the coast of New Zealand ("Obituary, Mr. F.J. Halse ", 1936, p. 10). He annotated a twentieth-century map tipped in to the rear pastedown with degrees and times, and, on the facing page, indexed some events and dates from the text. This volume returned at some point to the "pool of books" available for 
acquisition (Traue, 1991, p. 28) and entered Allan North's collection in the early 1950s, according to the date "14.2.53" North wrote next to his name on the front pastedown.

Alfred Kidd held both an 1823 and 1824 edition of Cruise's Journal (records 194, 197), but little can be learned of their histories as one carried the price $f 3.10$, the other had codes that may be a shelfmark. Sir George Fowlds held two copies of the 1823 edition (records 195-196), the first of which had a nineteenth-century inscription for possibly a "Dr Brown". The second copy had ink stamps that read: "Australian Subscription Library 1826" and "Free Public Library Sydney New South Wales" and a blind stamp that stated "Sold by the authority of the Trustees of the Public Library of New South Wales [overwritten in ink: Henry C L Anderson. Principal Librarian]". Established in 1826, the Australian Subscription Library was purchased by the New South Wales Government in 1869 to form the Sydney Free Public Library (SFPL), now part of the State Library (State Library New South Wales, 2013, November 19). The volume was among the Free Public Library duplicates sold through auction in 1897, and was listed under Lot 92 as "Cruise's 10 months residence in New Zealand 18232 vols" (James R. Lawson Pty, 1897, p. 9).

A prime example of how books shuttled between public and private owners, it was also the only sampled item for which a long ownership trail could be traced, if this volume was that listed in the 1830 catalogue for the Subscription Library as “Cruise's Residence in New Zealand, 1 vol. 8vo" (Australian Subscription Library, 1830, p. 13). If so, that means it was held for at around 67 years in Australian institutional hands, for up to 28 years by Fowlds, and by the University of Auckland Library since 1925.
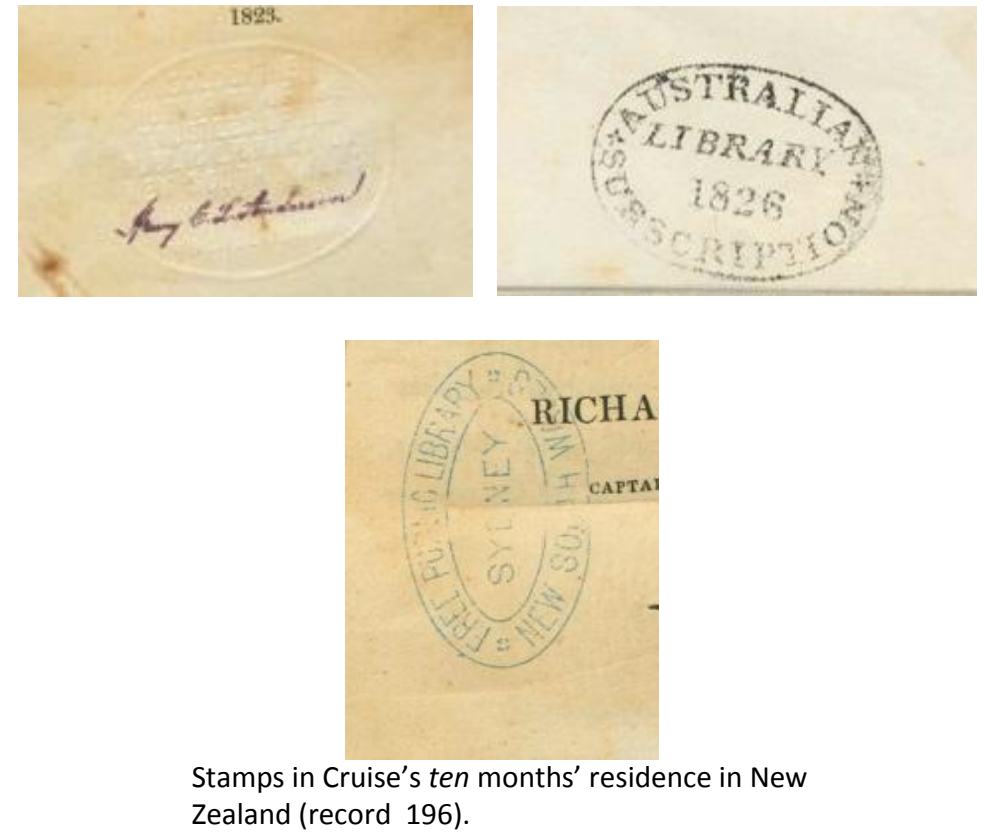
Fowlds had a second title that contained the "Sold by authority..." stamp, Charles Heaphy's Narrative of a residence... (1842, London, record 207), which was listed in the 1897 auction catalogue under lot 119 as "Heaphy's residence in New Zealand" (James R. Lawson Pty, 1897, p. 11). 


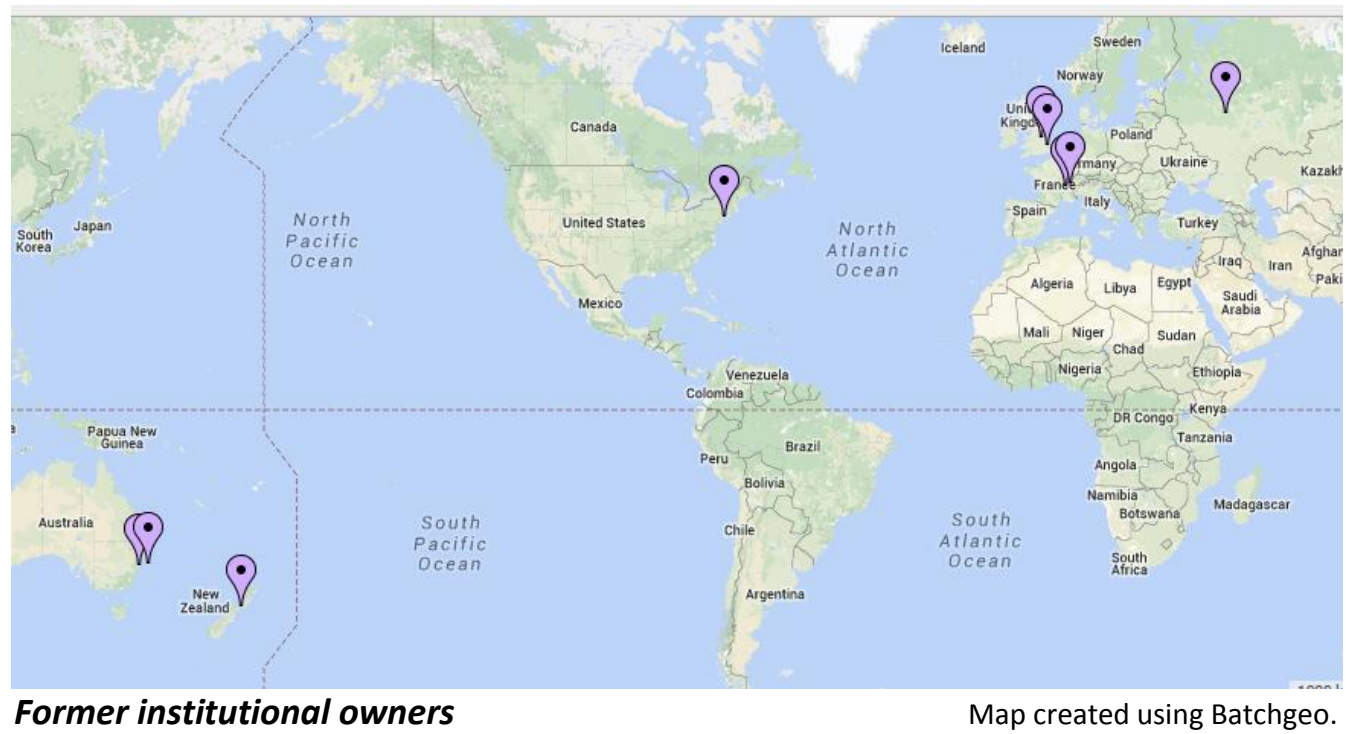

Looking more broadly at the former institutional owners ${ }^{13}$, most were in western Europe, Australasia and the United States. The outlier was a Russian military engineering institute, Voenno-Inzhenernoi Akademiia R.K.K.A , which stamped its mark in one of the two German language titles, John Nicholas' Reise nach und in Neuseeland in den jahren 1814 und 1815 mit den... (1819, Weimar, record 221). The Newark Book Society is discussed under the Alfred Kidd section, while the stories remain to be told of the volumes from the English Tottenham \& Edmonton Mechanics Literary \& Scientific Institution, the Camden Temperance Library, the French Jesuit order, and others. Although not known in all cases, the life-cycle events or ruptures that precipitated the onward journeys of some works included withdrawals as duplicates and the dispersal of libraries.

\section{Distribution}

Many of the sampled works were purchased through booksellers but only 14 companies ${ }^{14}$ could be identified from labels, stamps or loose bibliographic descriptions. Booksellers could have been responsible for many of the anonymous codes, prices and other markings, but this cannot be proven from the markings in the books alone. Three works ${ }^{15}$ contained markings that referred to Bethune, a leading New Zealand auction house (Ross, 1997, p. 203), with the sale dates spanning from the 1930s to the 1990s. Of the 14 booksellers, four were from New Zealand (active from the late nineteenth-century onwards), four from Australia (two present-day and two late nineteenth- to early mid-twentieth century). The three from England were all active around the late nineteenth- to early twentieth-century. The two Dutch and the American booksellers are modern-day.

\footnotetext{
${ }^{13}$ Records for former institutional owners: 1-2, 49, 126, 196, 207, 216, 221, 239, 289.

${ }^{14}$ Bookseller records: 3-4, 8, 19, 43, 50, 65, 66, 120-122, 123, 156, 178, 181, 210, 212, 222, 237-238, 245, $254,261$.

${ }^{15}$ Auction house records: 126, 198, 216.
} 


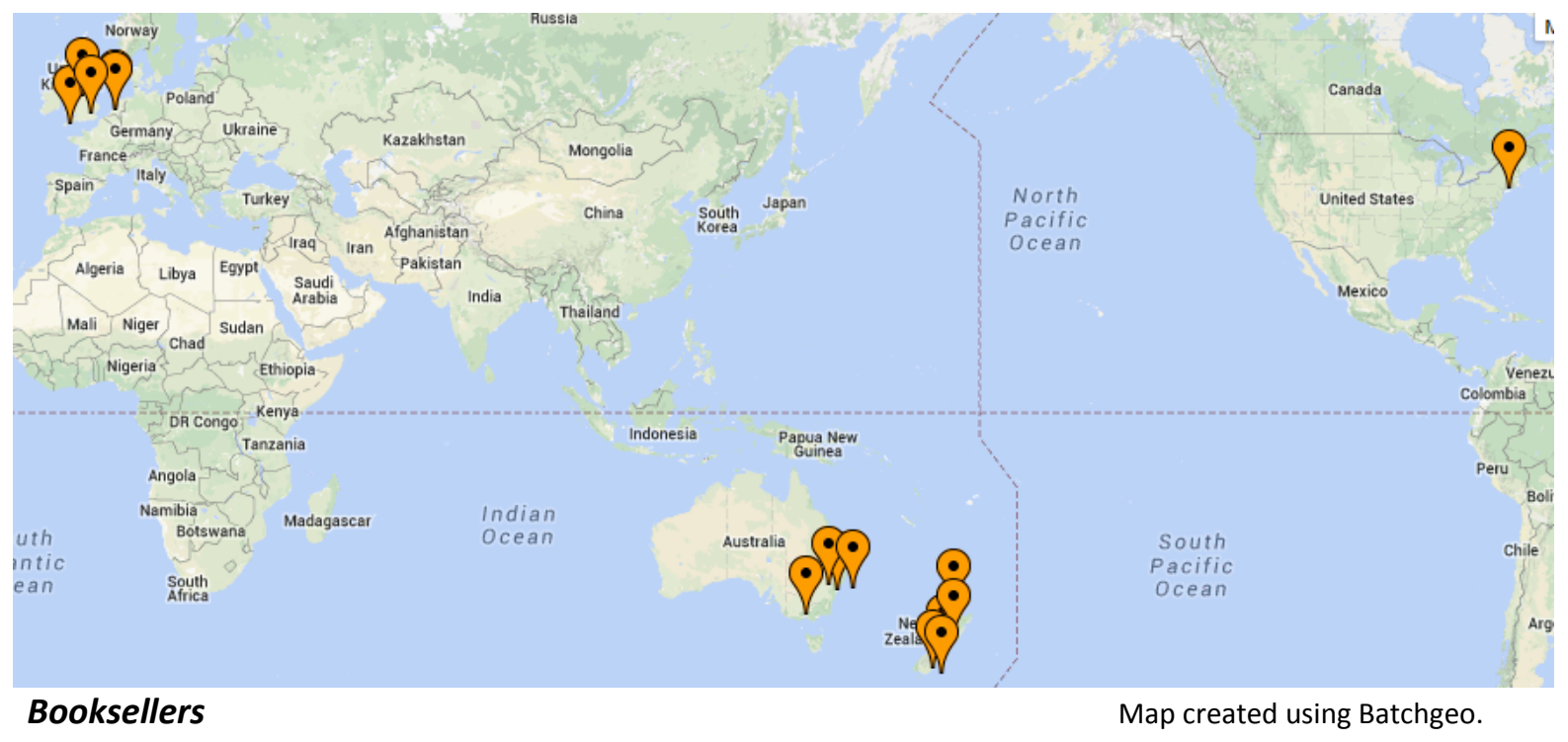

A possible connection could be drawn between one former owner and bookseller, based on their proximity. The two-volume, new edition of Polack's New Zealand: being a narrative of travels and adventures during a residence in that country... (1839, London, records 237-238) carried a yellow, oval-shaped label for "E. Nettleton, | Bookseller and Stationer | to the Queen | Plymouth". Edward Nettleton was a bookseller, printer, binder, and circulating library operator in Plymouth, Devon, from around the 1820 s until the 1850s (Maxted, 2007). It was probably Nettleton's bookselling arm that handled the work because in the nineteenth century it was inscribed, "J C. Mathews | Plymouth". Further research is needed to confirm whether this was the J.C. Mathews who was Superintendent of Emigration for the Plymouth Company, the subsidiary of Wakefield's New Zealand Company ("To the editor of the New Zealand Journal," 1841, p. 81). That same Mathews was later a subscriber to Charles Hursthouse's An account of the settlement of New Plymouth... (1849, London, record 209-210, p. xi). Allan North acquired the Polack work in 1952 , and likely paid the $£ 8-8.0$ price inscribed in ink on the front free endpaper of volume one.

The Andrew Kippis volume, The life of Captain James Cook (1788, Dublin, record 43), carried a label for Beazley, booksellers at 19 Churton St, Belgravia, London, who promised to "... supply any book wanted." There were no other markings to identify who they sold this work to, but the literature shows that Beazley's had a track record with other New Zealand

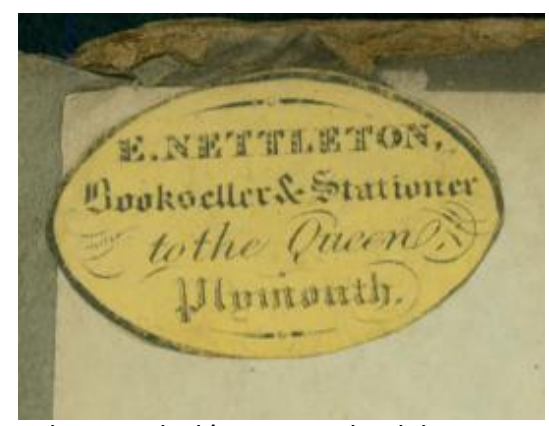

Ticket in Polack's New Zealand: being a narrative of travels... (records 237-238).

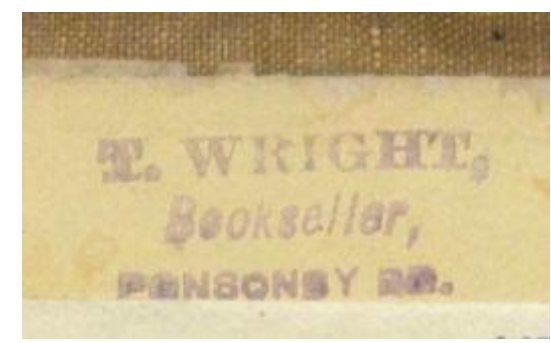

Stamp in Hursthouse's Account of the settlement of New Plymouth... (record 210). collectors, including F.W. Reed (Kerr, 2002, pp. 11-12). 
One of the local booksellers was Thomas Wright (1829 [ca.]-1912), who had a shop on Ponsonby Road from around the mid-1880s until the late 1890s, and then on Wellesley Street East ("Advertisements," 1898, p. 1; Deaths," 1912, p. 10).

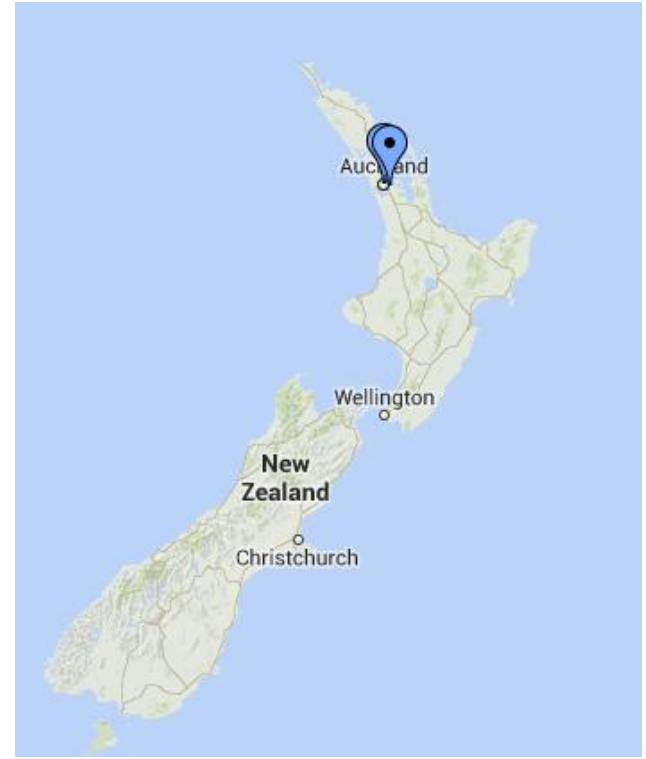

Binders

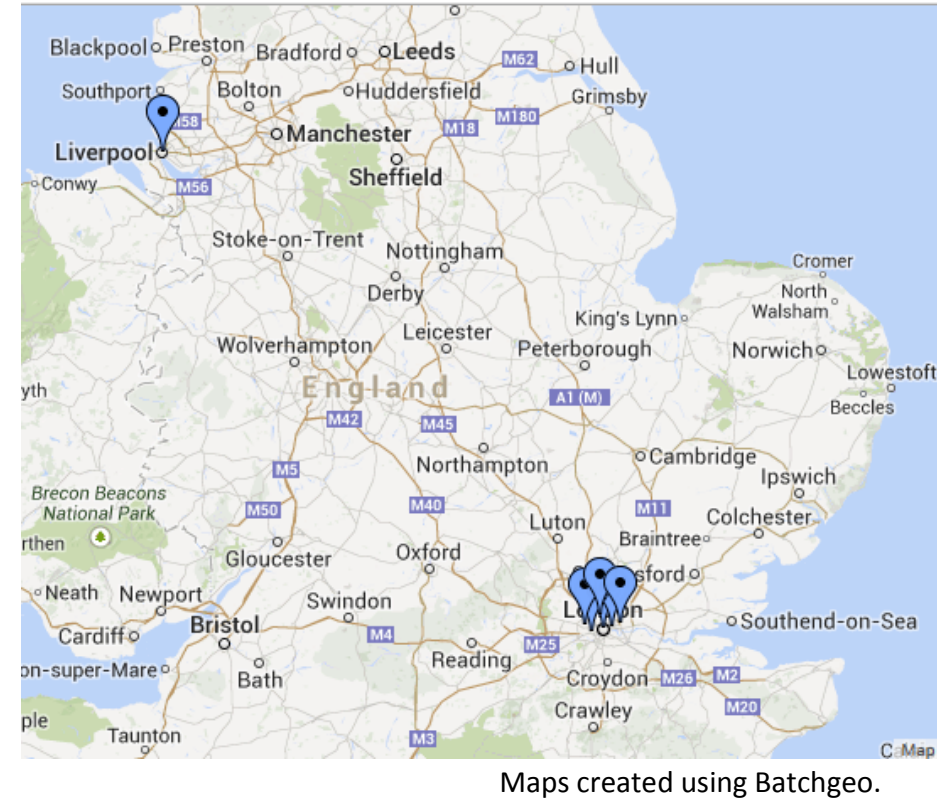

Maps created using Batchgeo.

Because binders connect with a multiplicity of agents, including printers, publishers, booksellers and owners, it was difficult to determine connections between the binders and the other agents. Of the tickets or stamps found for nine bookbinders ${ }^{16}$, six were from London, one was from Liverpool and two were from Auckland. Those that were located in the same cities in which the books were published and were contemporary with the texts may have been trade binders.

An eighteenth-century French work (record 69) bound in contemporary calf by the French binder Comte de AugusteMarie Caumont (1743-1839), who worked in London after the French Revolution (Maxted, 2012). The Auckland binders' tickets were in two works that were rebound in the twentieth century, one for the University's bindery (record

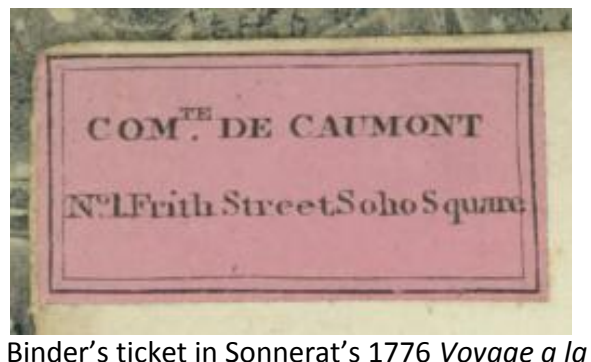

Binder's ticket in Sonnerat's 1776 Voyage a la Nouvelle Guinee... (record 69). 200-202), the other for Leighton, a long-standing Auckland binder (Lightbourne, 2000, p. 35) from the nineteenth-century who did binding and labelling for the Library.

\footnotetext{
${ }^{16}$ Bookbinder records: 69, 99-101, 157, 168-169, 200-202, 209, 210, 230-231, 289, 290-291.
} 


\section{Summary}

This section discussed some of the rich but fragmented evidence found among the sampled works, showing in some instances who once owned them and how they made their way to the shelves in Special Collections. For some there was no provenance information, while for others there remained lengthy gaps in their long histories. Filling those gaps was either outside the scope of this project or was not possible from the evidence.

So, what of Forrest's Voyage to New Guinea... with its ink sketches and multiple inscriptions? The identity of the bookplate's owner, A.L. Chappell, was discussed and the Library's purchase of his NZ\&P collection explains the book's presence in Special Collections. John Stewart of Wilmont may have been the last of the Stewart line to live at the Wilmont estate near Belfast in the early- to mid nineteenth-century. The identities of Alexander Anderson, of the nearby Lagan Village, Belfast, and Matthew Anderson and William Broun [?] remained elusive.
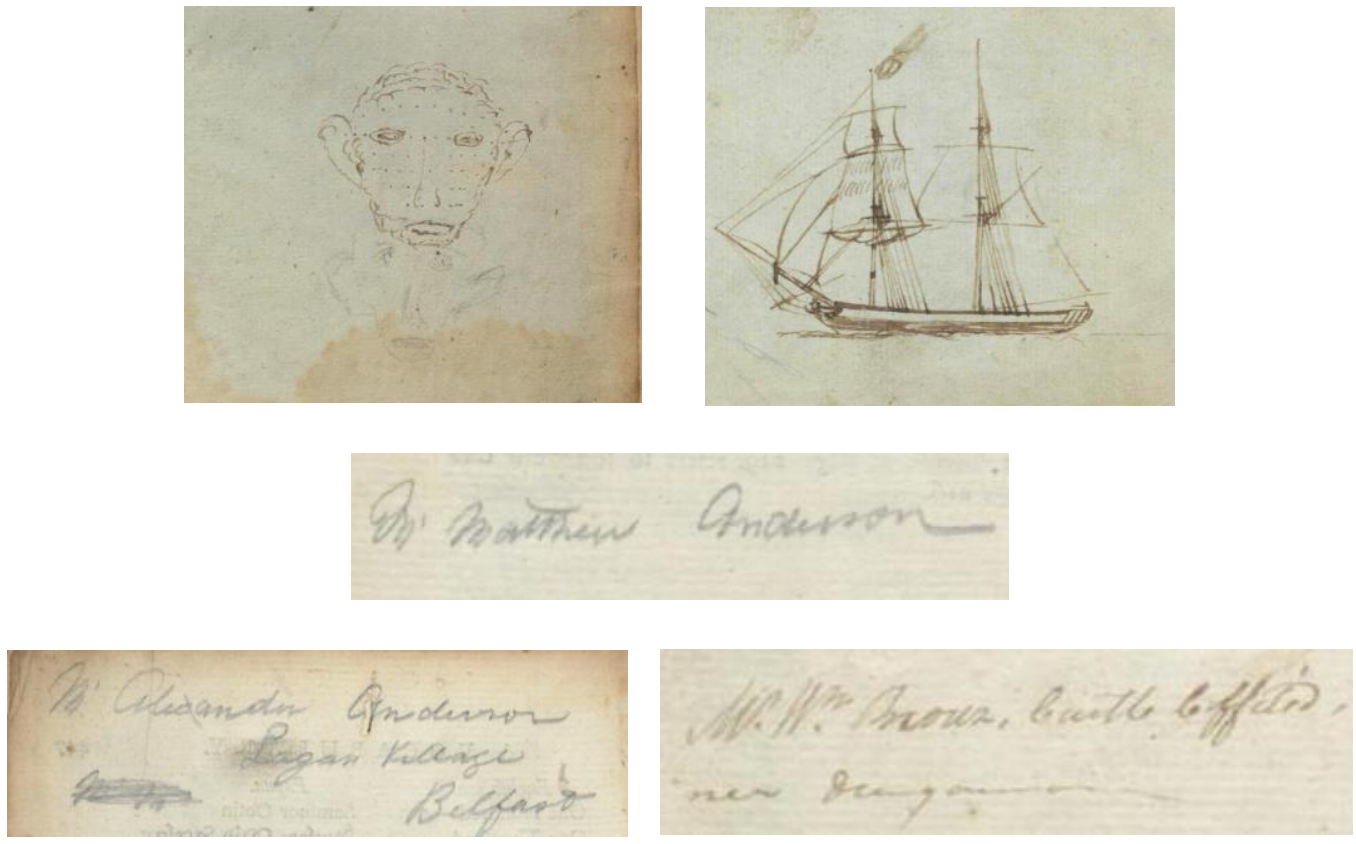

A selection of markings from Forrest's Voyage to New Guinea... (record 166). 


\subsection{Stage two: the collection of Alfred Kidd Esq.}

This section includes a brief biographical sketch of Alfred Kidd to provide some background for an examination of 250 works from his bequest and an exploration of the networks of ownership and distribution within that collection.

Five days after Alfred Kidd's death on 24 August 1917, the New Zealand Herald reported that the former Auckland mayor and parliamentarian had bequeathed about 400 books and an inlaid wood cabinet to Auckland University College ("Local and general news," 1917, p. 6). In September the following year, the College was officially notified of the bequest by lawyer and executor Joseph Stanton (Stanton, 1918). The College Council immediately acknowledged the bequest “... in a special letter of thanks, suitably engrossed, and sent to Mrs Kidd" (Auckland University College Council, 1918, September 16) and arranged to collect the items. The College also publicised the gift in the Calendar for 1919, saying, "The generosity of the late Mr. Alfred Kidd ... has made the College the possessor of a valuable collection of books relating to New Zealand. These, provided with a special book-plate acknowledging their donation in terms of $\mathrm{Mr}$ Kidd's will, are kept in a case specially constructed. It is hoped that they will form the nucleus of a growingly important section of the College Library" (Auckland University College, 1919, p. 19).

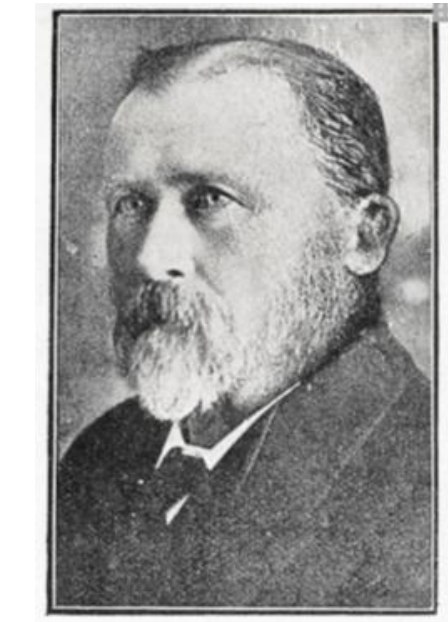

Alfred Kidd, from the Supplement to the Auckland Weekly News, August 30, 1917.

In March 1919, College Librarian Alice Minchin recorded in the accession register the details of 236 monographs and 16 bound volumes of pamphlets that formed Alfred Kidd's bequest (The University of Auckland Library, 1919, pp. 122-127). Including the 148 bound pamphlets, Alfred Kidd's gift amounted to some 384 works.

\section{Biographical sketch}

A teenage Alfred Kidd had arrived in Auckland in the mid 1860s, without any means. By the time of his death in 1917, he was a man of considerable wealth, high public standing and a book collector of some note. He was born ca. 1851 in Hounslow Heath, west of London (Chadwick, 1906, p. 287; Registrar of births deaths and marriages, 1917; Scholefield, 1908, p. 91). No accounts were found of his early life. 
After his arrival, Alfred Kidd first worked at Ascot, a farm in Mangere, Auckland, owned by Colonel Theodore Haultain and Colonel Nixon. In about 1867, he headed to the recently opened Thames goldfields, and prospected there for about seven years, after which he worked as a providore for the Waikato Steam Navigation Company (Chadwick, 1906, p. 287; Mr Alfred Kidd before the electors," 1902, p. 10).

In 1874, he married Christina Whisker ("Marriage," 1874, p. 2), daughter of Flora (nee Cook) and Alexander Whisker, a contractor and former soldier in the $58^{\text {th }}$ regiment (Mogford, 1990). The couple moved from Waikato to Auckland, where they went into the hotel trade. Alfred Kidd acquired the licence for the Provincial Hotel in 1876 ("Untitled," 1876, p. 2), the Anchor Hotel in 1877 ("Untitled," 1877, p. 2) and in 1878 for the Commercial Hotel, on the corner of Shortland and High Streets, which is now known as Hotel DeBrett ("Advertisements," 1878, p. 1). He remained the proprietor of the Commercial Hotel until 1903, although a manager was installed for at least 18 years and Christina Kidd played a key role in its running and held the licence at one point ("Presentation to Mr. and Mrs. Alfred Kidd.," 1903, p. 6; An unfortunate speculation," 1888, p. 3). They had four children, Alfred John (1875-1941), Flora Mary (1879-1958), Charles Alexander (18821947) and Francis George (1885-1966) (Internal Affairs; New Zealand Government, 1875-1983).

Kidd entered local politics in 1884 as a borough councillor for Auckland's East Ward. He remained in office until 1888, when he resigned after filing for bankruptcy when a property syndicate he was a part of failed due to the property slump and the withdrawal of some syndicate members ("Ellerslie land syndicate," 1888, p. 5). Kidd repaid his debt and the bankruptcy was annulled less than a year later ("Mr. A. Kidd's bankruptcy annulled," 1889, p. 5). He had restored his fortunes by the mid1890 s at the latest, by which time he had reportedly made $£ 30,000$ from the mining boom ("Pars about people," 1896) and was a director of multiple mining companies ("Trade topics," 1897, p. 11). He also went into partnership in a bookselling firm, Kidd and Wildman, in the mid-1880s.

Alfred Kidd was re-elected as a councillor in 1892 and then became the Mayor of Auckland for two years from mid-1901 (Bush, 1971, p. 584), after Sir John Logan Campbell's retirement. He had occasionally served as acting Mayor during the terms of David Goldie and Sir John ("Mr. Alfred Kidd.," 1901, p. 815). In November 1902, he was elected as the Liberal Member of the House of Representatives (MHR) for Auckland City ("Mr Alfred Kidd," 1902, p. 3) and was elected MHR for Auckland Central in 1905 after the division of the City seat. He was Senior Government Whip in the Richard Seddon and Joseph Ward administrations (Scholefield, 1908, p. 91) before losing his seat in 
1908. That placed him in parliament at the same time as fellow collectors, Sir George Fowlds and Robert McNab.

The Kidds ended their connection with the Commercial Hotel in 1903 ("Presentation to Mr. and Mrs. Alfred Kidd.," 1903, p. 6), the same year they moved into Hounslow, a large residence they had commissioned from Auckland architect George Goldsboro' at what is now 74 Gillies Ave (Waite, 2013, p. 5). Christina Kidd died in November 1904 during Kidd's first term in parliament ("Death of Mrs. Alfred Kidd," 1904, p. 3). In April 1907, he married Ethel Bridgman (1876-1947), then the matron of the Cambridge Sanatorium. Ethel Kidd led an active public life, including as a member of the Auckland Hospital Board, president of the Registered Nurses' Association and vice-president of the National Council of Women ("Death of Mrs E.A. Kidd.," 1947, p. 10). They had two children, Malcolm James (1908-1983) and Lindsay Robert (1912-1971) (Internal Affairs; New Zealand Government, 1875-1983). Early in their marriage, the couple travelled to Australia and the Pacific, as well as to Europe and Britain. During the latter trip, they saw the 1911 Coronation of King George V in London ("Customs character \& countries," 1911, p. 12) and were presented at court ("Personal notes from London," 1912a, p. 11; Personal notes from London," 1912b, p. 3).

Alfred Kidd was also a chairman of the Auckland Harbour Board, member of the Charitable Aid Board, trustee of the Auckland Savings Bank and president of the Auckland Racing Club. A Freemason and member of the Foresters and Druids' orders ("Obituary," 1917, p. 6), Kidd also bred thoroughbred horses and pedigree cattle on farms he owned near Waiuku (Chadwick, 1906, p. 287).

Overall, Kidd fit the mould of many local book collectors "... who as well as constituting a large part of the membership of various societies and organisations, often took roles in politics at a local and national level" (Hughes, 2013, p. 36). He was, however, also distinguished by being a bookseller and publisher for a short time. 


\section{Alfred Kidd's bequest}

Alfred Kidd's bequest was the first significant gift of NZ\&P-related books to the AUC Library. No public record was found that explained why he left his collection to the University, although an interest in education was evident through the years he spent on the Auckland Grammar School Board of Governors (Trembath, 1969, p. 364). He was an ex officio member of the Auckland University College Council from mid-1901 until mid-1903 by virtue of his position as the mayor of Auckland and he had personal associations with many Collegians. The AUC Council chairman, Sir G. Maurice O'Rorke and some professors and councillors were also on the Grammar School Board and many were members of the New Zealand Institute. Kidd's first employer,

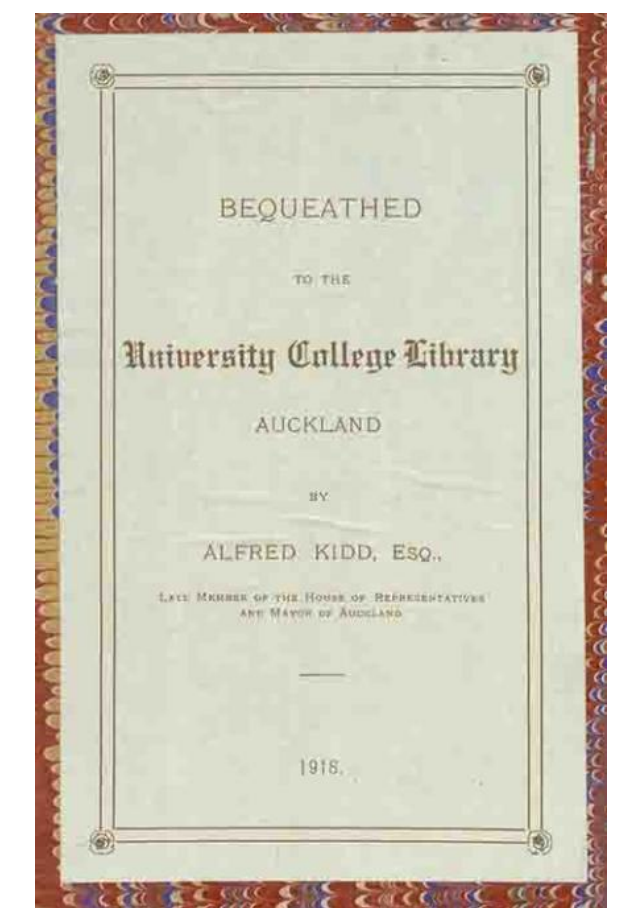

The label placed inside the volumes from Alfred Kidd's bequest. Colonel Haultain, was one of the founding AUC councillors and his friend and fellow Liberal MHR Sir George Fowlds was also on the AUC Council (Sinclair \& McNaughton, 1983, p. 306).

Kidd may also have been inspired by the gifts to other libraries by his fellow book collectors, particularly that of Sir George Grey; he had attended the ceremony for laying the foundation stone for the library which was built to house Grey's collection ("The Auckland free public library and art gallery," 1885, p. 6). And, as an AUC Councillor, Kidd was present at Council meetings when it discussed donations to the Library, including one from Reader Wood (Auckland University College Council, 1902) , whom Kidd knew and heard speak at a meeting to arrange the illuminated address for Sir George Grey ("Sir George Grey," 1886, p. 6).

\section{Collection overview}

Kidd's collection was relatively modest in size, yet it spanned all of the major New Zealand and Pacific collecting areas: travel and exploration, colonial history, missionary endeavours, natural sciences, Māori language and culture, and a smattering of bibliographic works and fiction. The collection was heavily weighted towards travel, exploration and history (The University of Auckland Library, 1919, pp. 122-127). The un-itemised works in the bound volumes covered similar subject matter, plus, among other things, Native Land Court judgments, emigrant manuals, political and 
financial tracts , and some unexpected titles, such as des Chesnais' Animal magnetism and spirit mediums (1884, Wellington).

The majority of his works were published before 1900 - nine works before 1800, 62 between 1800 and 1850 inclusive, and 300 between 1851 and 1899 inclusive. Only 13 works were published after 1900. This could suggest that Alfred Kidd's collecting interest was centred firmly on the pre-1900 period and that works published after that date were not acquired, or that any such works were not gifted to the University.

Kidd's travel and exploration books included the multi-volume sets on Cook's voyages (records 1112, 14-16, 20-22), James Ross' Voyage of discovery and research in the southern Antarctic regions... (1847, London, records 290-291) and Otto von Kotzebue's A voyage of discovery, into the South Sea and Bering's Straits... (1821, London, records 99-101). His Australian and Pacific-related holdings included George Keate's An account of the Pelew Islands... (1788, London, record 280), John Oxley's Journals of two expeditions into the interior of New South Wales... (1820, London, record 176) and Sir George Grey's Journals of two expeditions of discovery in north-west and western Australia (1841, London). New Zealand travel narratives featured strongly, such as Kerry-Nicholl's 1884 The King country or exploration in New Zealand, the first book in Alexander Turnbull's collection (McCormick, 1961, p. 21), and many other standards that were noted in Andersen's Lure of New Zealand book collecting (Andersen, 1936). Kidd's bequest included te reo Māori grammars and dictionaries and works on Māori history and culture. Among his missionary-related works were John Nicholas' Narrative of a voyage to New Zealand... (1817, London, records 217-218) and John William's A Narrative of missionary enterprises in the South Sea Islands... (1838, London). Natural and biological sciences were represented with various works on New Zealand's flora, fauna, marine life and geology, reflecting his 26-year membership of the Auckland Institute (New Zealand Institute, 1884$1909,1916)$. Kidd was not listed as an author of any papers in the Institute's journal and he does not appear to have authored any articles elsewhere.

Gaining a full understanding of Kidd's collecting practice is limited without the insights provided by personal papers but evidence that suggested he was a deliberate collector was found in one of his titles. The York Gate Library catalogue was compiled by Edward Petherick for the collection of London merchant and bibliophile S. William Silver (Petherick, 1886). Coincidentally, Petherick was the protagonist in the book in which Rukavina developed her concept of rhizomorphic book trade networks (2010). In his copy of the Petherick catalogue, Kidd used his preferred pencil to place ticks next to numerous titles in the New Zealand section (Petherick, 1886, pp. 271-282), all of which were 
listed in his bequest. Some items that Kidd owned were not ticked, so it is unclear whether the marks represented purchases or were made to show his interest, something which "book collectors do when going through a catalogue and dreaming of those books they would like to own" (Kerr, 2006 , p. 99). He may have used his copy of J.D. Davis's Contributions towards a bibliography of New Zealand literature (1887) in a similar way, but this could not be confirmed as his accessioned copy was not located. Other bibliographic works that he owned included a rare, ca. 1870s catalogue for Edward Wayte's Auckland Circulating Library (ca. 1870s, Auckland), Clifford Holgate's Account of the chief libraries of New Zealand (1886, London), a four-page book list from Specimen (n.d., record 393), and G.B. Barton's Literature in New South Wales (1866, Sydney, record 517).

Since their arrival at the University nearly 100 years ago, the volumes have been housed in specially designated repositories, such as the Glass Case and New Zealand Glass Case. When they were accessioned in 1919, the Library was in temporary quarters in the old Auckland Grammar School hall. The Library then moved in 1927 into the new ClockTower building (Johnson, 1988, pp. 2, 6) and into the current General Library building in 1968. The books were housed with other rare or fragile items in the NZ\&P section and, since 2001, in the NZ Glass Case in Special Collections.

Most of Kidd's books from both samples were still in contemporary bindings, including eighteenth century full calf and nineteenth-century cloth or paper boards, while some had been rebound by the Library, reflecting their use over nearly a century in a research collection. Binder's tickets for Leighton's of High Street, Auckland, were pasted into three works (records 290-291, 456) but it is not possible to say who commissioned the binding as the Library used that firm in the early twentieth century and Kidd may have done so, too, as the business was located near the Commercial Hotel. A label for the University's own bindery dates to the 1960s, while two others represent earlier London bookbinders, G. Peck (record 99-101), and Westleys \& Co. [records 209, 500).

Overall, Kidd's collection carried few clues to his ownership, except for the bequest labels and accession numbers. Two of the stage one sampled books had "A. Kidd" in pencil while a handful of items from the wider bequest had mostly pencilled inscriptions for "Alf. Kidd" and "Alfred Kidd". None of the inscriptions were dated. One twovolume work carried an ink stamp.

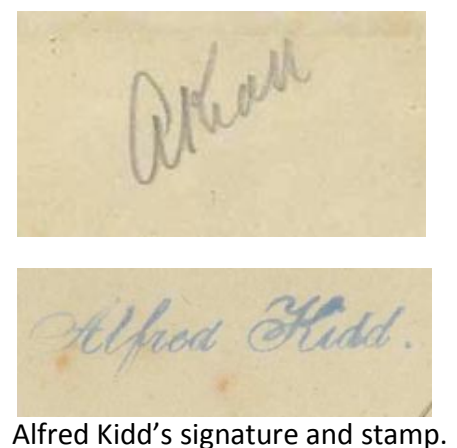




\section{Contemporary accounts of Alfred Kidd's library}

In one of a number of eulogies delivered in Parliament for Kidd, William Jennings, a fellow Liberal and Auckland Grammar School Board member, said,

Perhaps the best characteristic of Mr. Kidd, and one which is not generally known, except to those very intimately acquainted with him, was his great love of books. I have seen many libraries in New Zealand, but I have not seen one, with the exception of the Parliamentary Library, that had so many published works on New Zealand as had that of the late Mr. Kidd (New Zealand Parliament, 1917, 7 August - 7 September, p. 752).

Jennings' comment that Kidd's love of books was little known seems at odds with various newspaper reports that acknowledged Kidd as a book collector of some repute. It also seems that Kidd's library attracted a wider audience than some private collections because it was housed for an unknown number of years at the Commercial Hotel.

Kidd did not write acquisition dates in his books and without papers it is difficult to assess over what period of time he assembled his collection, but, by the mid-1880s, his library was established enough to attract public comment. This timing puts Kidd among New Zealand's second generation of book collectors (Traue, 1991, p. 34). In a letter to the editor about the need for a city-wide approach to building a New Zealand-related book collection in Auckland, "Agricola" wrote that Kidd, "... has the best private collection of books on New Zealand that is probably to be found in the city, and having paid attention to the subject of collecting, will understand the force of the City Council and the Museum authorities co-operating instead of competing..." ("New Zealand literature and records," 1886, p. 3).

Another newspaper story reported that the Irish MP and Home Rule activist John Dillon had visited Kidd's library at the hotel and was "... greatly astonished at finding so complete a collection of works relating to New Zealand and the colonies" ("Untitled," 1890, p. 4). It went on to note that Kidd's collection, “... has been

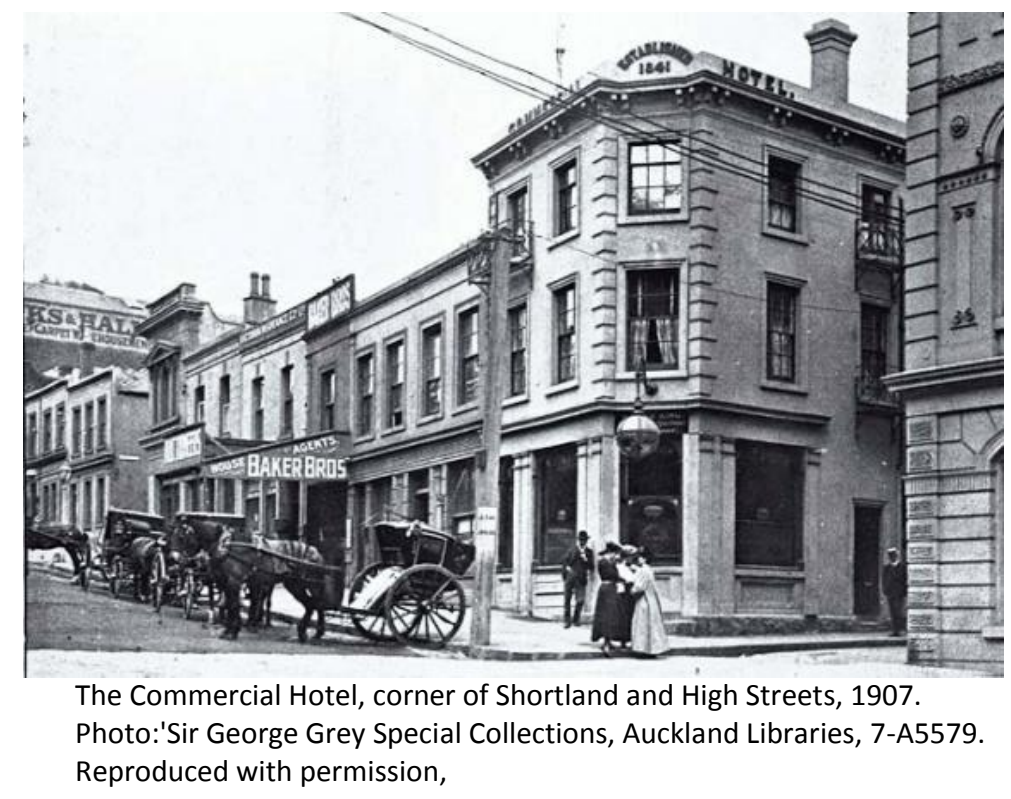


inspected by a large number of distinguished visitors, the most recent being Sir John Thurston, Governor of Fiji, and Commissioner of the Western Pacific" ("Untitled," 1890, p. 4).

An 1897 profile on Kidd in the Sporting Review and Licensed Victuallers Gazette, included this description of his library:

The walls of the little library room are covered with pictures all denoting good taste, together with testimonials of various kinds which have been presented by members of local bodies and other institutions to which Mr Kidd belonged ("Trade topics," 1897, p. 11).

\section{Exploring networks}

The examination of Alfred Kidd's works from both samples turned up evidence for a handful of former owners, booksellers and bookbinders, revealing a variety of distribution and ownership networks in action (see Appendix 3 and 4).

\section{Distribution}

The provenance markings showed that Alfred Kidd sourced his collection from various strands of the secondary book distribution network (Adams \& Barker, 1993, p. 25), including acquiring works as gifts, presentation copies and through the second-hand book trade.

Only one of Kidd's books from the stage one sample contained evidence that conclusively identified a bookseller, even though all were second-hand when he acquired them. Inside the Angas folio, The New Zealanders illustrated, was a label for "Matthews and Brooke, Booksellers, Bradford" [record 178]. Without invoices or receipts, it could be proven he purchased the book from that firm, but, thanks to a newspaper article, an acquisition date and price could be pin-pointed. In an 1894 piece railing against "temperance cranks who love to paint the hotel-keeper as a species of devil incognito", Kidd was praised as a publican and city councillor with discernment and an "admirably stocked" library, who had just acquired The New Zealanders for $f 25$ ("Topics of the week.," 1894, p. $603)$. This volume would have enhanced any well-stocked library of the time; Alexander Turnbull purchased a set of The New Zealanders plates in the original covers for $£ 18$ in 1889 (Barrowman, 1995, p. 73) and later advised another collector he would not pay more than $f 25$ for the volume (Barrowman, 1995, p. 221), while Sir George Grey received a presentation copy from the author 
(Kerr, 2006, p. 248). A bookseller's label found in a volume from Kidd's wider bequest was for "Bain, | Bookseller, | 1 Haymarket". This was in the second edition of J.D. Lang's ... Historical and statistical account of New South Wales (1837, London) which also carried an illegible inscription dated 1837.

Some of the works in Kidd's collection were gifts. For example, a rare copy of Gilbert Cuzent's L'archipel des iles de la Société: I'annexion de Taïti à la France (1885, Brest) was bound with a letter to Kidd from Lieutenant James C. Cresap of the U.S. corvette Mohican. The Mohican had berthed in Auckland on the afternoon of 16 August 1886 and it was just three days later that Cresap wrote to Kidd, suggesting that the Commercial Hotel was an early port of call ("Arrival of the U.S. corvette Mohican.," 1886, p. 2). In his letter, Cresap wrote to Kidd: "I send you herewith the copy of "Society Groups" by $\mathrm{Dr}$ Cuzent, which I read with great interest and which I believe would make an addition to your unique and valuable little library" (Cresap, 1886, p. 1). In a postscript, Cresap said "I regret that it is so poorly bound and hope you may think it worth a substantial

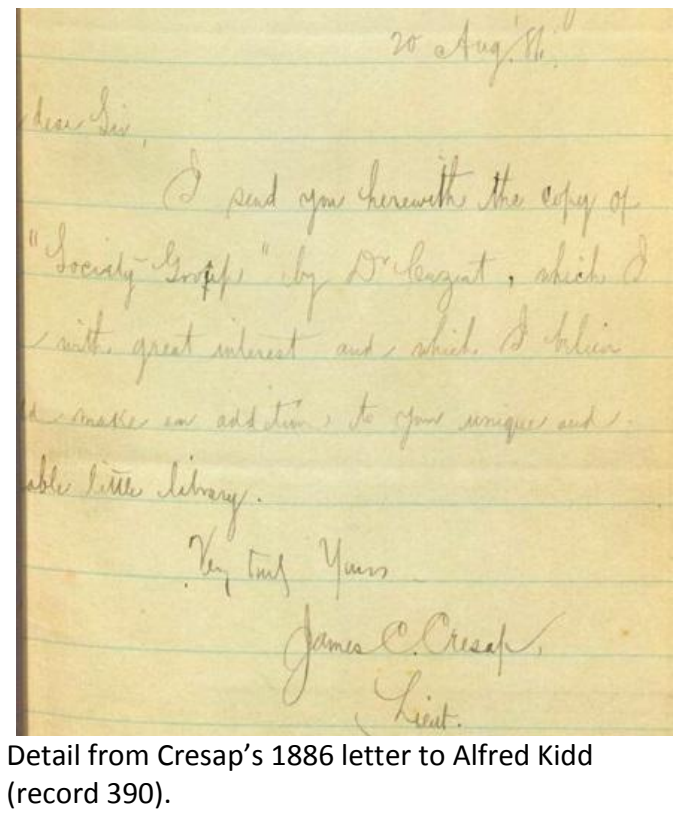
(record 390). binding" (Cresap, 1886, p.2), which Kidd apparently did not. This item suggests that the formation of Kidd's library was enhanced by being housed in a semi-public place, while its status as a gift explained its presence in a collection that contained no other European-language titles. Another gift was the copy of G.B. Barton's Literature in New South Wales (record 517), which had the inscription: "Mr. Alfred Kidd from R.A.A. Sherrin 6-9-1891 Auckland". Richard Arundell Augur Sherrin (18321893) wrote numerous books and co-authored The early history of New Zealand... (1890, Auckland) that Kidd also possessed.

Kidd received presentation copies from authors, as was common for collectors, including Turnbull, Grey and Harding (McCormick, 1974; Kerr, 2006; Hughes, 2013). Kidd's author presentations included W.E. Gudgeon's Maori migration to New Zealand..., a paper presented to the Polynesian Society (record 305) and James Kilgour's work on the federation of the British Empire (1888, Thames, record 382). A variation on this was the Memories of the life of J.F.H. Wohlers... (1895, Dunedin), which contained a tipped-in leaf on which John Houghton, the book's translator, wrote, "Alfred Kidd Esq | With the translator's very kind regards | Auckland Septr 10th / 96." 
A subscriber to the second edition of Sir Walter Buller's A history of the birds of New Zealand (Buller, 1888, p. XI Vol. 2), volume one of Kidd's copy was inscribed, "W.L. Buller May 1892" (record 466467). In an 1891 letter to Thomas Cheeseman, author and curator of the Auckland Institute and Museum, of which Kidd was a member, Kidd wrote "I have just received a memo from Sir WB re his Book. I will take my copy some time this month - about the end. Thanking you for keeping it so long. I remain Yours etc Alfred Kidd" (Kidd, 1891). It is unclear which book Kidd was referring to as Buller's inscription in A history of the birds... post-dated this letter and Kidd's other holdings of Buller's works provided no answers.

However, it was through Kidd's partnership with bookseller William Wildman (1843-1897) in the bookselling and publishing firm 'Kidd and Wildman' that his strongest connections with book distribution agents and networks were revealed. Evidence in some of his books showed that this venture was also an acquisition source for his library, but just how significant a role it played was difficult to judge as no publicly held company records were located and no labels for the firm were found in his books.

In a profile on Alfred Kidd, The Observer noted that Kidd and Wildman was "... one of the bestappointed and most capably managed businesses of the kind in the city"("Men of the Time.," 1887, p. 17), positioned in the newly opened Victoria Arcade, on the corner of Queen and Shortland Streets. The partnership was established around October 1886 and continued until February 1888, when Kidd withdrew because of the difficulties stemming from the land syndicate ("An unfortunate speculation," 1888, p. 3). Newspaper advertisements for Kidd and Wildman ran until the 1890s, although it is unclear why because, by late 1889 , Wildman was invoicing customers on stationery printed with only his own name (Wildman, 1889, October 10); it was renamed Wildman and Lyell after Mr W.S. Lyell entered the firm ("Wildman and Lyell.," 1902, p. 407). Advertisements and newspaper reports show that Kidd and Wildman ran a diverse business from their shop, which was across and down the road from the Commercial Hotel. Their activities included publishing works by local authors,

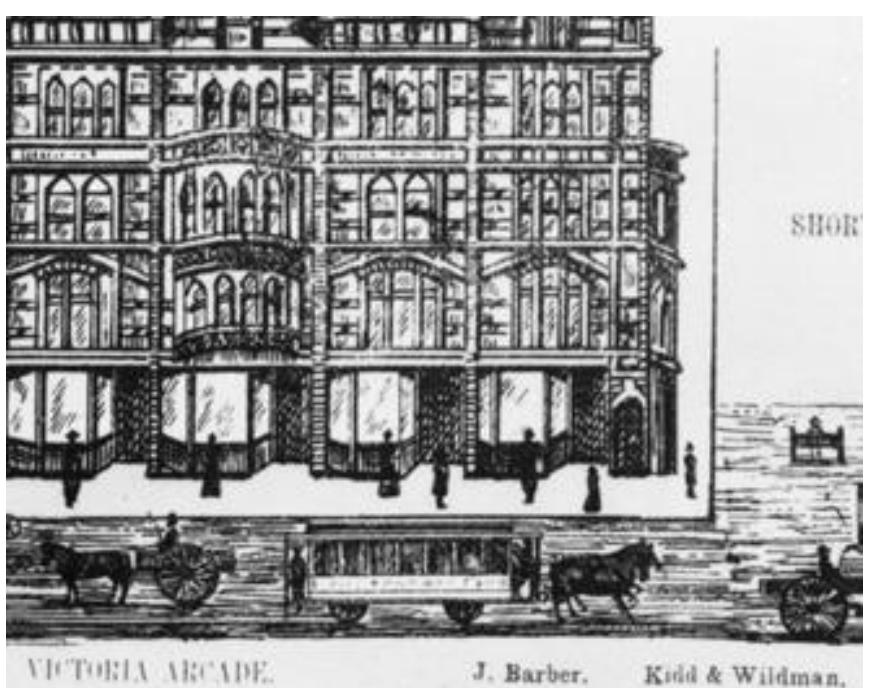

Detail from Brett's Almanac for 1887.

Sir George Grey Special Collections, Auckland Libraries, 4-337'. selling local and imported books, 
newspapers and stationery, running a box office for entertainment ticket sales and attracting customers with their window displays of pictures, illuminated addresses and furniture ("Advertisements," 1886, p. 4; English impressions of the Tarawera Eruption," 1886, p. 2; Untitled," 1887a, p. 4). The firm had some collectors and libraries on its books, including Sir John Hall (Kidd and Wildman, 1887, November 28) and the General Assembly Library (Lightbourne, 2000, p. 20).

A full-page advert in Brett's Almanac for 1888 showed the business dealt in works that attracted Kidd's collecting eye as it lists 18 recent titles, nearly all of which were in Kidd's collection. The advert also promoted their interest in buying older works:

"Persons possessing old Books or Pamphlets relating to the Colony are recommended to submit a list to K. \& W., who are open to give good prices for them" (Brett, 1888, pp. 1, advertisements). Some of the items in Kidd's bound pamphlet volumes may have been sourced that way.

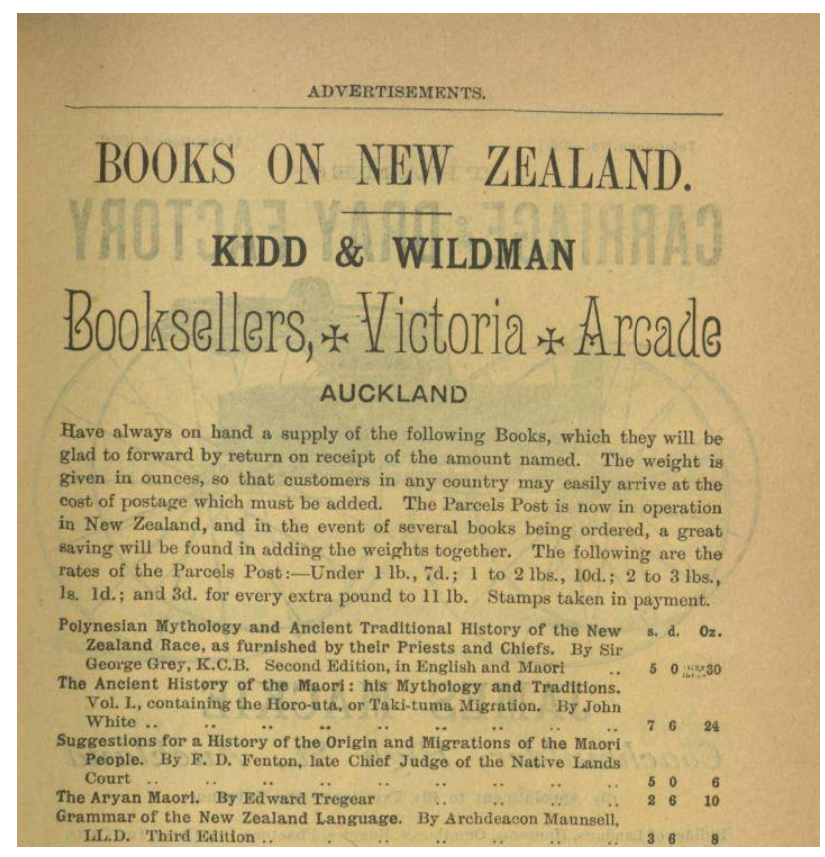

Detail from Brett's Almanac for 1888, p.1, advertisements. A tipped-in note from the printer Robert Coupland Harding to William Wildman, returning a William Woolls pamphlet on the Rev. Samuel Marsden (1844, Parramatta), certainly showed that particular item entered Kidd's collection via his association with Wildman (record 397). In 1887, a newspaper columnist reported that Kidd and Wildman had imported "... a fine collection of works..." related to land tenure ("Untitled," 1887b, p. 4), which may partly explain the presence among the pamphlets of the fourth edition of Annie Besant's Landlords, tenant farmers, and laborers... (1880, London).

The pamphlets also included two of the three Kidd and Wildman-published works listed in Te Puna, the national catalogue. Kidd's copy of James Mackay's Our dealings in Maori lands... (1887, Auckland) was inscribed "Alfred Kidd Esqre | With the authors compliments | James Mackay" (record 295). His copy of the Kidd and Wildman-published pamphlet, Financial depression: its causes and remedy (1886, Auckland), by R.D.L. Duffus, was unmarked. The bequest did not include a third Kidd and Wildman pamphlet, The curability and treatment of all diseases... by Dr Wilkins (1888, Auckland), which, according to Te Puna, is held only at the Hocken Library. 
Kidd's social, bibliographic and political networks converged in a 1906 exchange with his friend and Parliamentary colleague Sir George Fowlds, at that time the Liberal Minister of Education. In a letter to Fowlds, Kidd followed up on an earlier petition on behalf of a "Mr Suter of Auckland", who was seeking government funding for a book, and whom Kidd described as a "... splendid man for the subject" (Kidd, 1906). This was Henry Suter, an expert on molluscs and fellow member of the Auckland Institute (New Zealand Institute, 1906, p. 559), who was seeking financial backing for a new text on New Zealand molluscs (Beu, 1996). After successful lobbying, including from Augustus Hamilton, the Colonial Museum curator (Beu, 1996), Suter began on the work, which was eventually published as the Manual of the New Zealand Mollusca (1913, Wellington), and an atlas of plates in 1915. In the preface to the Manual, Alfred Kidd and Sir George were among those that Suter acknowledged for their assistance: "... they all most kindly assisted me in my task" (Suter, 1913, p. iv).

\section{Ownership}

Three earlier ca. nineteenth-century private owners of Kidd's books inscribed their names: George Bidwood, Walter Booth and R. Luggate (records 167, 174, 186), while Geo. D. McVay used a stamp (records 217-218). From the wider bequest sample, one two-volume set contained a nineteenthcentury armorial bookplate for William Hale (record 462-463). The bare ownership information those examples provided contrasted with another volume, which was packed with information about its ownership and how, when and to whom it was distributed.

Tipped in to his copy of William Power's Sketches in New Zealand... (1849, London, record 239) was a printed circulation label for the Newark Book Society. Active between 1777 and 1872 in Newark, Nottinghamshire, England, by the mid-nineteenth century the Book Society had around 25 members (Morley, 1968, p. 83), which tallied with the number listed on this label.

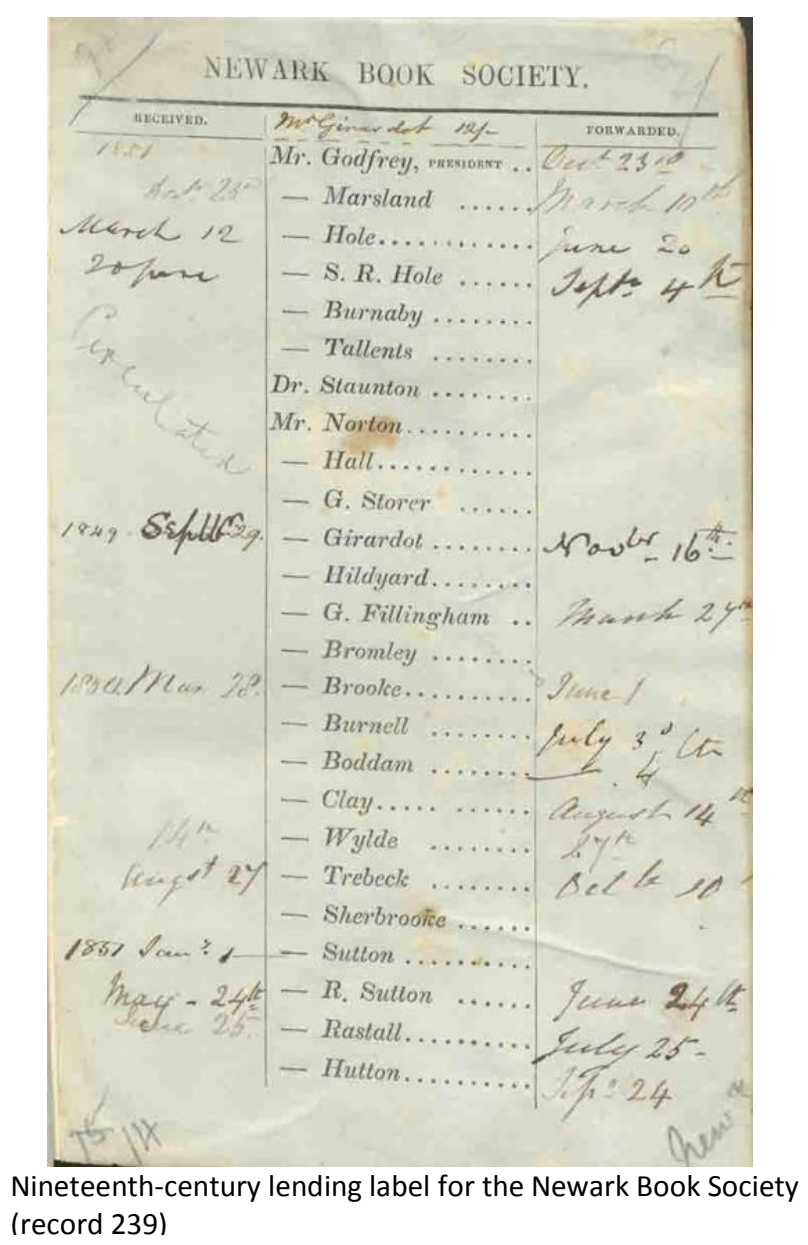


Under the Society's original rules, books were ordered by members, circulated around the group, starting with the person who placed the order, and were later auctioned off to members (Morley, 1968, p. 83), ensuring a supply of funds for new books. It appears the freshly published Sketches in New Zealand... was ordered by Mr Girardot at a cost of 12 shillings, was received by him on 29 September 1849 and forwarded on November 16, after which it was circulated to at least 14 others over the next two years. Who eventually acquired it is unknown, as was its whereabouts until it was acquired by Kidd.

Another title that was held in non-private hands before Kidd and suggests a potentially wide distribution was George Baden-Powell's New homes for the old country... (1872, London). Pasted to the front boards of both volumes were labels for The Auckland Circulating Library, with item numbers 493 and 494 written in ink. The proprietor, Edward Wayte (1827-1914), was a longtime Auckland bookseller who also ran a circulating library from his Queen Street premises "Death of Mr. W. Wildman.," 1897, p. 5). The library's terms notices were not inside the volumes as promised on the label and they contained no other marks, aside from those signalling Kidd's bequest. New homes... was listed in Kidd's ca. 1873 catalogue for Wayte's circulating library, but with a 492 item number against copy 2; items 493-494 were not

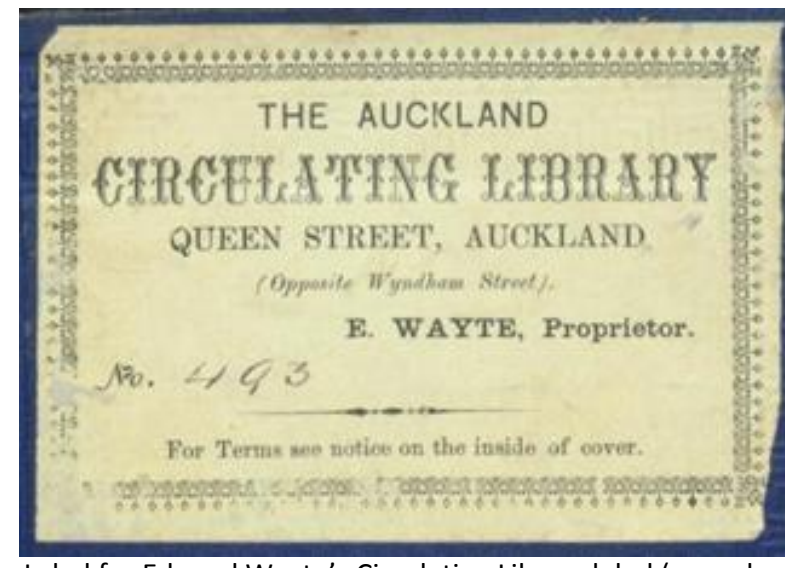

Label for Edward Wayte's Circulating Library label (records 481-482)

listed. It is not known when the title left the circulating library or how it entered Kidd's but a likely source is again through the Kidd and Wildman connection. Wildman was at one stage a manager in Wayte's firm ("Death of Mr. W. Wildman.," 1897, p. 5).

\section{Summary}

This section discussed the previously unexplored collection of Alfred Kidd, a successful self-made colonial man. It opened a window on the ownership and distribution histories of some of his books and provided some insight into the origins of a collection, which has, as the University predicted in 1919 , helped form the "... nucleus of a growingly important section of the College Library".

Although more remains to be researched and written about Alfred Kidd and his collection, enough is now known that he can be added to the roll call of New Zealand collectors who helped enrich our institutional collections. 


\subsection{Concluding remarks}

This project set out to investigate the provenance of some rare books in Special Collections because, as David Pearson has observed, "... all previous ownership is part of the historical fabric and is worth investigating" (2013, para. 19). It revealed that some volumes once stood on the book shelves of eighteenth-century Englishmen, nineteenth-century Spanish senoritas and twentieth-century New Zealand collectors, while others circulated between members of book clubs, subscription libraries and scientific institutes. The project found there were "collections within collections" (Pearson, 2009 , p. 3), including those from some lesser-known New Zealand bookmen who contributed to the early development of this slice of the rare books collection. It also illuminated the different ways some books were distributed, including through auction houses and booksellers and as gifts and bequests. This provenance evidence will eventually be available to researchers anywhere through enhanced Catalogue records. Already, though, it has helped to show that the New Zealand Glass Case is not just a mass of authors and titles but is instead made up of individual books, some with their own intriguing stories to tell.

The project's findings suggest that fruitful future research could include:

- A broader-based study into provenance evidence in Special Collections.

- In-depth studies into Alfred Kidd, Sir George Fowlds, Allan North and Arthur Lewis Chappell.

- A survey of institutional rare books repositories in New Zealand to learn about their provenancerelated cataloguing practices. 


\section{Appendices}

\section{Appendix 1: Sample data collection form}

The entire data collection form is shown here although most fields were not required for this particular record.

When necessary, additional rows were added to accommodate multiple instances of the same provenance type (e.g. 4.0a-c, 4.1a-c).

\begin{tabular}{|c|c|c|}
\hline $\begin{array}{l}\text { Record } \\
\text { No. }\end{array}$ & & 280 \\
\hline 1 & Bibliographical details & \\
\hline $1.0 \mathrm{a}$ & Call no. & 919.66 K25 cop. 1 \\
\hline $1.0 \mathrm{~b}$ & Vol. no. & \\
\hline $1.0 \mathrm{c}$ & Author & Keate, George, 1729-1797. \\
\hline $1.0 \mathrm{~d}$ & Published date & 1788. \\
\hline $1.0 \mathrm{e}$ & Title & $\begin{array}{l}\text { Account of the Pelew Islands: situated in the western part of the Pacific Ocean: composed from the } \\
\text { journals and communications of Captain Henry Wilson, and some of his officers, who, in August, 1783, } \\
\text { were there shipwrecked, in the Antelope... }\end{array}$ \\
\hline $1.0 f$ & City & London \\
\hline $1.0 \mathrm{~g}$ & Publisher & Printed for Captain Wilson. \\
\hline 2 & Bindings (describe) & Full leather, gilt to boards and spine, lettering piece. \\
\hline $2.0 a$ & Date (estimate) & Contemporary \\
\hline $2.0 \mathrm{~b}$ & $\begin{array}{l}\text { If customised, type: } \\
\text { Institutional/Personal/Unknown }\end{array}$ & \\
\hline $2.0 c$ & $\begin{array}{l}\text { If customised, how: Armorial/Personalised (e.g. } \\
\text { initials) }\end{array}$ & \\
\hline $2.0 \mathrm{~d}$ & Shelfmarks (exterior): & \\
\hline $2.0 \mathrm{e}$ & Notes: & \\
\hline 3.0 & $\begin{array}{l}\text { Auckland University College (AUC) / University } \\
\text { of Auckland (UoA) Library accession/processing } \\
\text { marks (summarise) }\end{array}$ & $\begin{array}{l}\text { White ink } z \text { and call no. to spine. } \\
\text { AUC Regulations label with NZ Collection stamp and Accession number: } 8418\end{array}$ \\
\hline $3.0 a$ & Location: & Spine, front pastedown, verso title page \\
\hline
\end{tabular}




\begin{tabular}{|c|c|c|}
\hline $3.0 \mathrm{~b}$ & Notes: & \\
\hline 4.0 & Markings (transcribe) & No other marks. Clean text block. \\
\hline $4.0 a$ & Location: & \\
\hline $4.0 \mathrm{~b}$ & $\begin{array}{l}\text { Type: codes (bookseller, owner, price), } \\
\text { shelfmarks, unknown, other }\end{array}$ & \\
\hline $4.0 \mathrm{c}$ & Notes: & \\
\hline 5.0 & Inscription (transcribe) & \\
\hline $5.0 a$ & Location: & \\
\hline $5.0 \mathrm{~b}$ & Notes: & \\
\hline 6.0 & Annotation (summarise) & \\
\hline 7.0 & Bookplate (transcribe) & \\
\hline $7.0 \mathrm{a}$ & Location: & \\
\hline $7.0 \mathrm{~b}$ & Type: Institutional/ Personal/ Unknown & \\
\hline $7.0 \mathrm{c}$ & $\begin{array}{l}\text { Style: Armorial/ Pictorial/ Pictorial- } \\
\text { armorial/Typographic }\end{array}$ & \\
\hline $7.0 \mathrm{~d}$ & Notes: & \\
\hline 8.0 & Book label (transcribe) & $\begin{array}{l}\text { Bequeathed | to the | University College Library | Auckland | by | Alfred Kidd, Esq., | Late Member of } \\
\text { the House of Representatives | and Mayor of Auckland. | } 1918 .\end{array}$ \\
\hline $8.0 a$ & Location: & Front pastedown \\
\hline $8.0 \mathrm{~b}$ & $\begin{array}{l}\text { Type: Institutional / Personal / Presentation / } \\
\text { Donation / Bequest }\end{array}$ & Bequest \\
\hline $8.0 \mathrm{c}$ & Notes: & \\
\hline 9.0 & Book stamp (transcribe) & \\
\hline $9.0 \mathrm{a}$ & Location: & \\
\hline $9.0 \mathrm{~b}$ & Institutional / Personal / Unknown & \\
\hline $9.0 \mathrm{c}$ & Notes: & \\
\hline 10.0 & Booksellers' label/stamp (transcribe) & \\
\hline $10.0 \mathrm{a}$ & Location: & \\
\hline $10.0 \mathrm{~b}$ & Notes: & \\
\hline
\end{tabular}




\begin{tabular}{|l|l|l|}
\hline 11.0 & Binders' ticket/stamp (transcribe) & \\
\hline $11.0 \mathrm{a}$ & Location: & \\
\hline $11.0 \mathrm{~b}$ & Notes: & \\
\hline 12.0 & Other, e.g. tipped in or loose items (summarise) & \\
\hline $12.0 \mathrm{a}$ & Location: & \\
\hline 13.0 & Miscellaneous (summarise) & \\
\hline $13.0 \mathrm{a}$ & Location: & \\
\hline
\end{tabular}




\section{Appendix 2: Provenance evidence for all identifiable agents}

This appendix lists all of the stage one sampled items that contained provenance evidence for identifiable former owners, booksellers and binders.

Note: The lengthier book titles are abbreviated, as are the binding descriptions. The sources for the brief biographical details about some owners are not in the references. Please contact the researcher for details.

Key: AUCL: Auckland University College Library (1883-1961); UoAL (University of Auckland Library, post-1961).

\begin{tabular}{|c|c|c|}
\hline $\begin{array}{l}\text { Record } \\
\text { no. }\end{array}$ & Title details & Provenance evidence (stage one sample) \\
\hline 001-002 & $\begin{array}{l}\text { Richard, A; Lesson, P.A.; Dumont d'Urville, J-S-C. (1832-34). Voyage de } \\
\text { decouvertes de l'Astrolabe: execute par ordre du Roi pendant les annees } \\
\text { 1826-1827-1828-1829 sous le commandement de M.J. Dumont d'Urville, } 2 \\
\text { vols. Paris: J. Tastu. } \\
\text { Binding: ca. 19th century quarter leather and marbled boards. }\end{array}$ & $\begin{array}{l}\text { Stamp, title page, vol. 2: Conservatoire | Botanique | Ville de Geneve } \\
\text { Stamp, FFEP, vol. 1-2: Duplicata de le bibliotheque | du conservatoire botanique } \\
\text { de geneve | vendu en } 1922 \\
\text { Pictorial bookplate, front pastedown, vol. 1-2: Ex libris | The Horticultural Society } \\
\text { of New York } 1902 \text { | Bequest of | Kenneth K. Mackenzie | October } 1934 \\
\text { Loose label, vol. 1-2: Department of Botany | Auckland University | V.J. Chapman } \\
\text { Memorial Collection } \\
\text { [Valentine J. Chapman (1910-1980), Professor of Botany at the University of } \\
\text { Auckland from 1945-1974]. }\end{array}$ \\
\hline 003-004 & $\begin{array}{l}\text { Bennett, F.D. (1840). Narrative of a whaling voyage round the globe, from } \\
\text { the year } 1833 \text { to 1836: comprising sketches of Polynesia, California, the } \\
\text { Indian archipelago, etc..., } 2 \text { vols. London: L.R. Bentley. } \\
\text { Binding: contemporary cloth boards. }\end{array}$ & $\begin{array}{l}\text { Bookseller's label, front pastedown, vol. 1-2: Angus \& Robertson, } 89 \text { Castlereagh } \\
\text { St., Sydney | Between King \& Market Sts. } \\
\text { Inscription, front pastedown vol. 1: [illegible] }\end{array}$ \\
\hline 007 & $\begin{array}{l}\text { Bligh, W. (1792). A voyage to the South Sea: undertaken by command of His } \\
\text { Majesty, for the purpose of conveying the bread-fruit tree to the West } \\
\text { Indies in His Majesty's Ship, The Bounty... Dublin: Printed by H. Fitzpatrick } \\
\text { for P. Wogan... [et. al.]. } \\
\text { Binding: ca. 19th century half leather and marbled boards. }\end{array}$ & $\begin{array}{l}\text { Armorial bookplate, front pastedown: G R Bethell } \\
\text { [May indicate George Richard Bethell (1849-1919), Commander in the Royal Navy } \\
\text { and Conservative politician for Holderness]. } \\
\text { AUCL presentation label, front pastedown: Presented | to the | University College } \\
\text { Library | Auckland | By | Hon. George Fowlds }\end{array}$ \\
\hline
\end{tabular}




\begin{tabular}{|c|c|c|}
\hline $\begin{array}{l}\text { Record } \\
\text { no. }\end{array}$ & Title details & Provenance evidence (stage one sample) \\
\hline & & $\begin{array}{l}\text { [After this shortened to AUCL presentation label: George Fowlds]. } \\
\text { Markings, verso FFEP: Coll. AM | 14/-. f5.10. }\end{array}$ \\
\hline 008 & $\begin{array}{l}\text { Bougainville, L-A. (1771). Voyage autour du monde par la fregate du roi La } \\
\text { Boudeuse, et la flute L'Etoile, en 1766, 1767, 1768, \& 1769. Paris: Chez } \\
\text { Saillant \& Nyon...: De l'imprimerie de Le Breton... } \\
\text { Binding: contemporary full leather. }\end{array}$ & $\begin{array}{l}\text { Armorial bookplate, front pastedown: Fide et Amore. I Library, I Ragley Hall. } \\
\text { [Ragley Hall, Warwickshire, the seat of the Marquess of Hertford, Conway } \\
\text { Seymour family]. } \\
\text { Shelf marks: D. [printed]: } 53 \text { [MSS] S. [printed]: D [MSS] } \\
\text { Bookseller's label, front pastedown: Messrs | Berkelouw }\end{array}$ \\
\hline 010 & $\begin{array}{l}\text { Barrow, J. (1831). Eventful history of the mutiny and piratical seizure of } \\
\text { H.M.S. Bounty: its cause and consequences... London: John Murray. } \\
\text { Binding: contemporary cloth. }\end{array}$ & $\begin{array}{l}\text { AUCL gift label, front pastedown: This book is from the collection given to the } \\
\text { Library by J.C. Entrican. } \\
\text { Ink inscription, ca. 19th century, FFEP: H Townshend | [... unclear] } \\
\text { Markings, rear pastedown: W 4/141 | A } 3 / 2\end{array}$ \\
\hline 011-012 & $\begin{array}{l}\text { Cook, J. (1790). Captain Cook's voyages round the world: The first } \\
\text { performed in the years } 1768,1769,1770,1771 \text {; the second in } 1772,1773 \text {, } \\
\text { 1774, 1775; the third and last in 1776, 1777, 1778, 1779, and } 1780 \text {..., } 2 \\
\text { vols. Newcastle: H. Brown. } \\
\text { Binding: ca. 20th century half leather and cloth boards. }\end{array}$ & $\begin{array}{l}\text { AUCL bequest label, front pastedown, vol. 1: Bequeathed | to the | University } \\
\text { College Library | Auckland. | By James Leask . | Date: } 12^{\text {th }} \text { November } 1895 . \\
\text { [A journalist and teacher, the Scottish-born James Leask Sinclair (1829-1895), } \\
\text { emigrated to New Zealand in } 1865 . \text { He corresponded with Charles Darwin). } \\
\text { Pencilled markings [mathematical calculations], ca. 19th-20th century, RFEP, vol. } \\
\text { 1. }\end{array}$ \\
\hline 014-16 & $\begin{array}{l}\text { Hawkesworth, J. (1773). An account of the voyages undertaken by the order } \\
\text { of His Present Majesty for making discoveries in the southern hemisphere, } \\
\text { and successively performed by Commodore Byron, Captain Carteret, } \\
\text { Captain Wallis, and Captain Cook..., } 3 \text { vols. London: Printed for W. Strahan } \\
\text { and T. Cadell. } \\
\text { Binding: ca. 18th-19th century full leather, gilt. }\end{array}$ & $\begin{array}{l}\text { AUCL bequest label, front pastedown, vol. 1-3: Bequeathed | to the | University } \\
\text { College Library | Auckland | by | Alfred Kidd, Esq., | Late Member of the House of } \\
\text { Representatives | and Mayor of Auckland. | 1918. } \\
\text { [After this shortened to AUCL bequest label: Alfred Kidd]. } \\
\text { Accession: } 8414-8416 .\end{array}$ \\
\hline 017-018 & Hawkesworth, J. (1775). An account of the voyages undertaken by the & AUCL presentation label, front pastedown, vol. 1-2: George Fowlds. \\
\hline
\end{tabular}




\begin{tabular}{|c|c|c|}
\hline Record & Title details & Provenance evidence (stage one sample) \\
\hline & $\begin{array}{l}\text { order of His present Majesty, for making discoveries in the southern } \\
\text { hemisphere, and successively performed by Commodore Byron, Captain } \\
\text { Carteret, Captain Wallis, and Captain Cook ..., } 2 \text { vols. Dublin: James Potts. } \\
\text { Binding: contemporary full mottled calf, gilt. }\end{array}$ & \\
\hline 019 & $\begin{array}{l}\text { Marra, J. (1775). Journal of the Resolution's voyage, in 1772, 1773, 1774, } \\
\text { and } 1775, \text { on discovery to the southern hemisphere, by which the non- } \\
\text { existence of an undiscovered continent, between the Equator and the 50th } \\
\text { degree of southern latitude is demonstratively proved... London: Printed for } \\
\text { F. Newbery. } \\
\text { Binding: Publisher's paper boards, uncut edges. }\end{array}$ & $\begin{array}{l}\text { Bookseller's label, 21st century, phasebox: Gaston Renard Pty. Ltd. I Fine and Rare } \\
\text { Books since } 1945 \text { | ... }\end{array}$ \\
\hline $020-022$ & $\begin{array}{l}\text { Cook, J. (1784). A voyage to the Pacific Ocean: undertaken by the command } \\
\text { of His Majesty, for making discoveries in the northern hemisphere... } \\
\text { performed under the direction of Captains Cook, Clerke, and Gore in His } \\
\text { Majesty's ships Resolution and Discovery in the years 1776, 1777, 1778, } \\
\text { 1779, and } 1780 . ., 3 \text { vols. Dublin: Printed for H. Chamberlaine ; W. Watson ; } \\
\text { Potts ; Williams; Cross; Jackson ; Moncrieffe... } \\
\text { Binding: Full calf boards, gilt. }\end{array}$ & AUCL presentation label, front pastedown, vol. 1-3: George Fowlds. \\
\hline 027-030 & $\begin{array}{l}\text { Cook, J. (1784). A voyage to the Pacific Ocean: undertaken by command of } \\
\text { His Majesty for making discoveries in the northern hemisphere: performed } \\
\text { under the direction of captains Cook, Clerke, and Gore, in the years 1776, } \\
1777,1778,1779, \text { and } 1780 \text {..., Abridged. } 4 \text { vols. London: Printed for J. } \\
\text { Stockdale, Scatcherd and Whitaker... } \\
\text { Binding: } c a .20^{\text {th }} \text { century half leather and marbled boards, gilt. }\end{array}$ & $\begin{array}{l}\text { Ink inscription, dedication page: Vol. 1: Wm Carlen | } 1 \text { August } 1784 \\
\text { Vol. 2: Wm. Carlen's Book | } 1 \text { August } 1784 \\
\text { Vol. 3: Wm.. Carlens.. Book | } 1 \text { August } 1784 .\end{array}$ \\
\hline 031-033 & $\begin{array}{l}\text { Cook, J., \& King, J. (1785). A voyage to the Pacific ocean. Undertaken, by the } \\
\text { command of His Majesty, for making discoveries in the northern } \\
\text { hemisphere. Performed under the direction of Captains Cook, Clerke, and } \\
\text { Gore, in His Majesty's ships the Resolution and Discovery; in the years 1776, } \\
\text { 1777, 1778, 1779, and 1780..., } 3 \text { vols. London: G. Nicol and T. Cadell. } \\
\text { Binding: ca. 19th century full calf, gilt. }\end{array}$ & $\begin{array}{l}\text { AUCL bequest label, front pastedown, vol. 1-3: Alfred Kidd. } \\
\text { Accession: 8409-8411. }\end{array}$ \\
\hline 034-035 & $\begin{array}{l}\text { (1831). A voyage to the Pacific Ocean, under the direction of captains Cook, } \\
\text { Clerke, and Gore, in the years } 1776,7,8,9 \text {, and } 80 \text { : with an introductory } \\
\text { review of maritime discovery down to the time of Captain Cook, } 2 \text { vols. } \\
\text { Edinburgh: Printed for Henry Constable.; London: Hurst, Chance, \& Co. } \\
\text { Binding: Vol 1: ca. } 19^{\text {th }} \text { century cloth. }\end{array}$ & $\begin{array}{l}\text { Armorial bookplate, front pastedown, vol. 1-2: Ex armis honos | Chas. Ogilvy Esqr. } \\
\text { [From the Ogilvy family of Forfar, Scotland]. } \\
\text { [From the collection of the Rev. W.J. Comrie]. }\end{array}$ \\
\hline
\end{tabular}




\begin{tabular}{|c|c|c|}
\hline Record & Title details & Provenance evidence (stage one sample) \\
\hline & & Ink and pencil annotations, $\mathrm{ca} .20^{\text {th }}$ century to preliminary pages. \\
\hline 036 & $\begin{array}{l}\text { Rickman, J. (1781). Journal of Captain Cook's last voyage to the Pacific } \\
\text { Ocean: on Discovery performed in the years 1776, 1777, 1778, } 1779 \text {... } \\
\text { London: Printed for E. Newbery. } \\
\text { Binding: ca. 18th-19th century half leather and marbled boards, gilt. }\end{array}$ & $\begin{array}{l}\text { Ink inscription, verso frontispiece: Woodside Library | old Windsor | Berkshire } \\
\text { Pencilled markings, verso FFEP. }\end{array}$ \\
\hline 037-038 & $\begin{array}{l}\text { Cook, J. (1777). A voyage towards the South Pole, and round the world: } \\
\text { performed in His Majesty's ships the 'Resolution 'and 'Adventure', in the } \\
\text { year } 1772,1773,1774 \text {, and } 1775 . . ., 2 \text { vols. London: Printed for W. Strahan } \\
\text { and T. Cadell. } \\
\text { Binding: ca. 19th century full calf, gilt. }\end{array}$ & $\begin{array}{l}\text { AUCL bequest label, front pastedown, vol. 1-2: Alfred Kidd. } \\
\text { Accession: 8426-8427. }\end{array}$ \\
\hline $039-040$ & $\begin{array}{l}\text { Cook, J. \& Furneaux, T. (1784). A voyage towards the South Pole, and round } \\
\text { the world: Performed in His Majesty's ships the Resolution and Adventure, } \\
\text { in the years } 1772,1773,1774 \text {, and } 1775 \ldots, 2 \text { vols. Dublin: Printed for J. } \\
\text { Williams, L. White, W. Wilson, C. Jenkin, P. Byrne, and R. Burton. } \\
\text { Binding: full speckled calf. }\end{array}$ & AUCL presentation label, front pastedown, vol. 1-2: George Fowlds. \\
\hline 043 & $\begin{array}{l}\text { Kippis, A. (1788). The life of Captain James Cook... Dublin: Printed for } \\
\text { Messrs. H. Chamberlaine, W. Colles [etc]. } \\
\text { Binding: ca. 18th-19th century full calf. }\end{array}$ & $\begin{array}{l}\text { Bookseller's label, front pastedown: Supplied by | Beazley, | Booksellers, I } \\
\text { Belgravia. | 19, Churton St., S.W. | Who can supply any book wanted. }\end{array}$ \\
\hline 047 & $\begin{array}{l}\text { Beautemps-Beaupre, C.F. (1807). Atlas du voyage de Bruny-Dentrecasteaux, } \\
\text { Contre-Admiral de France, commandant les Fregates la Recherche de } \\
\text { I'Esperance, fait par ordre du Gouvernement en 1791, } 1792 \text { et } 1793 . . . \text { Paris: } \\
\text { Depot General des Cartes et Plans de la Marine et des Colonies. } \\
\text { Binding: cloth and paper boards, uncut edges. }\end{array}$ & $\begin{array}{l}\text { Label, title page: Bibliotheque | de Monsieur de Boynes, | a Bellavilliers. [MSS: No } \\
\text { 917] } \\
\text { Pencil marking, front pastedown: [struck through] E-3235 | Rare | s2 vol. \& Atlas } \\
\text { [struck through]. | [... illegible] } 19 \text { | E3238 }\end{array}$ \\
\hline 048 & $\begin{array}{l}\text { Fanning, E. (1833). Voyages round the world: with selected sketches of } \\
\text { voyages to the South Seas, North and South Pacific Oceans, China, etc. New } \\
\text { York: Collins \& Hannay. } \\
\text { Binding: contemporary paper boards, cloth spine. }\end{array}$ & $\begin{array}{l}\text { AUCL presentation label: George Fowlds. } \\
\text { Pencil inscription, n.d., FFEP: Aaron M Burt [surrounded by wreath and ribbon]. }\end{array}$ \\
\hline 049 & $\begin{array}{l}\text { Fleurieu, C. P. C. (1790). Découvertes des François, en } 1768 \text { \& 1769, dans le } \\
\text { sudest de la Nouvelle Guinée. Et reconnoissances postérieures des mêmes } \\
\text { terres par des navigateurs anglois qui leur ont imposé de nouveaux noms... } \\
\text { Paris: Imprimerie royale. } \\
\text { Binding: ca. 18th century marbled leather, gilt. }\end{array}$ & $\begin{array}{l}\text { Stamp, title page: Domus Lugdunensis Soc. Jesu. I J M[?] S } \\
\text { [Society of Jesuits, Lyon, France]. }\end{array}$ \\
\hline 050 & $\begin{array}{l}\text { Fleurieu, C. P. C. (1791). Discoveries of the French in } 1768 \text { and 1769, to the } \\
\text { South-East of New Guinea... London: John Stockdale. }\end{array}$ & $\begin{array}{l}\text { Bibliographic description, laid in, by 21st century bookseller, Gert Jan } \\
\text { Bestebreurtje, Utrecht The Netherlands. }\end{array}$ \\
\hline
\end{tabular}




\begin{tabular}{|c|c|c|}
\hline Record & Title details & Provenance evidence (stage one sample) \\
\hline & Binding: 19th century half calf and marbled boards, gilt. & \\
\hline $051-052$ & $\begin{array}{l}\text { Forster, G. (1777). A voyage round the world in His Britannic Majesty's } \\
\text { sloop, Resolution, commanded by Capt. James Cook, during the years 1772, } \\
\text { 3, } 4 \text { and 5..., } 2 \text { vols. London: Printed for B. White, Fleet-Street J. Robson, } \\
\text { Bond Street; P. Elmsly, Strand... } \\
\text { Binding: ca. 19th century full calf, gilt. }\end{array}$ & $\begin{array}{l}\text { AUCL bequest label, front pastedown, vol. 1-2: Alfred Kidd. } \\
\text { Accession: } 8412-8413 \text {. }\end{array}$ \\
\hline 054 & $\begin{array}{l}\text { Hombron, J.B. (1847). Aventures les plus curieuses des voyageurs, coup } \\
\text { d'oeil autour du monde, d'après les relations anciennes et modernes et des } \\
\text { documents recueillis sur les lieux..., vol. 2. Paris: Belin-Leprieur et Morizot. } \\
\text { Binding: contemporary cloth, gilt. }\end{array}$ & $\begin{array}{l}\text { Ink inscription, FFEP: Pequena prueba de Amistad a la Srta. Maria Carrera y } \\
\text { Ravina/Ravira [?] | de la apinto [?] | A.P. I Cadiz } 14 \text { Julio } 1854 \\
\text { [Loose translation of 'Pequena prueba de Amistad': small sign of friendship] }\end{array}$ \\
\hline 055 & $\begin{array}{l}\text { Jacobs, T.J. (1844). Scenes, incidents, and adventures in the Pacific Ocean, } \\
\text { or the islands of the Australasian Seas, during the cruise of the clipper } \\
\text { Margaret Oakley, under Capt. Benjamin Morrell... New York: Harper \& } \\
\text { Brothers. } \\
\text { Binding: contemporary cloth boards, gilt. }\end{array}$ & Pictorial bookplate, ca. 20th century, front pastedown: Donald P. Dukehart \\
\hline $056-058$ & $\begin{array}{l}\text { La Perouse, J-F, de la. (1799). Voyage round the world, performed in the } \\
\text { years 1785, 1786, 1787, and 1788, by the Boussole and Astrolabe, under the } \\
\text { command of J.F.G. de La Perouse ..., } 3 \text { vols. London: Printed by A. Hamilton, } \\
\text { for G.G. and J. Robinson... } \\
\text { Binding: Vol. 1-2: ca. 19th century full tree calf, gilt. Vol 3: ca. 19th century } \\
\text { half calf and marbled boards, gilt. }\end{array}$ & $\begin{array}{l}\text { Armorial bookplate, short title page, vol. 1-2: Nec aspera terrent | Libertas et } \\
\text { natale solum | Sir George P. Adams. } \\
\text { [General Sir George Pownall Adams, of Bowden, Devonshire, born 1779, died } \\
\text { 1856, East Budleigh, Devonshire: served in the army in India and Ireland, knighted } \\
\text { in 1831]. }\end{array}$ \\
\hline 060-061 & $\begin{array}{l}\text { Dillon, P. (1829). Narrative and successful result of a voyage in the south } \\
\text { seas: performed by order of the Government of British India, to ascertain } \\
\text { the actual fate of La Pérouse's expedition... London: Hurst, Chance. } \\
\text { Binding: Vol. 1: contemporary half-leather and marbled boards. Vol. 2: 20th } \\
\text { century cloth. }\end{array}$ & $\begin{array}{l}\text { AUCL bequest label, front pastedown, vol. 1: Alfred Kidd. } \\
\text { Accession: } 8228-8229\end{array}$ \\
\hline 064 & $\begin{array}{l}\text { Tyerman, D., \& Bennet, G. (1841). Voyages and travels round the world, by } \\
\text { Daniel Tyerman and George Bennet, deputed from the London Missionary } \\
\text { Society to visit their various stations in the South Sea Islands, Australia, } \\
\text { China, India, Madagascar, and South Africa, between the years } 1821 \text { and } \\
\text { 1829, compiled from original documents by James Montgomery. 2nd. ed., } \\
\text { corrected. London: J. Snow. } \\
\text { Binding: ca. 19th century full leather, gilt. }\end{array}$ & $\begin{array}{l}\text { Ink inscription, ca. } 20^{\text {th }} \text { century, FFEP: Ronald M. Arndell. } \\
\text { Author inscription on tipped-in leaf: To | The Revd. William Henry | from the } \\
\text { Director | and with the cordial regards | of his obliged friend | George Bennet | } \\
\text { Mission House | Jany } 251841 \\
\text { Pencil inscription, title page: P.H. Henry. }\end{array}$ \\
\hline
\end{tabular}




\begin{tabular}{|c|c|c|}
\hline $\begin{array}{l}\text { Record } \\
\text { no. }\end{array}$ & Title details & Provenance evidence (stage one sample) \\
\hline 065 & $\begin{array}{l}\text { Cook, J., \& Hawkesworth, J. (1778). New discoveries concerning the world } \\
\text { and its inhabitants in two parts...: comprehending all the discoveries made } \\
\text { in the several voyages of Commodore (now Admiral) Byron; Captains Wallis, } \\
\text { Carteret, and Cook... London: printed for J. Johnson. Copy } 2 . \\
\text { Binding: ca. contemporary full calf, gilt. }\end{array}$ & $\begin{array}{l}\text { Ink inscription, ca. 20th century, front pastedown: JW. Thomson | Port Chalmers. } \\
\text { Ink inscription, front pastedown: [...? E] Ker | Willoughthorpe | Herts. } \\
\text { Armorial bookplate, front pastedown: John Gray [MSS on plate: Gray of } \\
\text { Dalmarnock). } \\
\text { Armorial bookplate, front pastedown: anonymous. } \\
\text { Bookseller's label, laid in: Pam Plumbly Rare and Antiquarian Books ... Dunedin. } \\
\text { Markings on front pastedown. }\end{array}$ \\
\hline 066 & $\begin{array}{l}\text { Parkinson, S., \& Parkinson, S. (1773). A journal of a voyage to the South } \\
\text { Seas, in his Majesty's ship, the Endeavour / faithfully transcribed from the } \\
\text { papers of the late Sydney Parkinson, draughtsman to Joseph Banks, esq. on } \\
\text { his late expedition, with Dr. Solander, round the world... London: Printed for } \\
\text { Stanfield Parkinson, the editor. } \\
\text { Binding: contemporary full calf, rebacked, gilt. }\end{array}$ & $\begin{array}{l}\text { Anonymous armorial gilt crest, front and rear boards. } \\
\text { [Egerton, Francis Henry, 8th Earl of Bridgewater (1756-1829). Refer University of } \\
\text { Toronto armorial bindings website, Egerton, FH, stamp 6]. } \\
\text { Bibliographic description, laid in, by 21st century US bookseller Wm Reese. }\end{array}$ \\
\hline 067 & $\begin{array}{l}\text { Parkinson, S., Parkinson, S., Fothergill, J., Cook, J., Lettsom, J.C. \& Kenrick, } \\
\text { W. (1784). A journal of a voyage to the South Seas in His Majesty's ship the } \\
\text { Endeavour / faithfully transcribed from the papers of the late Sydney } \\
\text { Parkinson... London: Printed for Charles Dilly... and James Phillips... } \\
\text { Binding: contemporary quarter leather and marbled boards, uncut edges. }\end{array}$ & Faint ink inscription, ca. 18th-19th century, title page: [...?] Lackie or Mackie [?] \\
\hline 068 & $\begin{array}{l}\text { Shillibeer, J. (1817). A narrative of the Briton's voyage to Pitcairn's Island } \\
\text { including an interesting sketch of the present state of the Brazils and of } \\
\text { Spanish South America, } 2 \text { nd. ed. London: Printed for Law and Whittaker. } \\
\text { Binding: contemporary paper boards. }\end{array}$ & AUCL presentation label, front pastedown: George Fowlds. \\
\hline 069 & $\begin{array}{l}\text { Sonnerat, P. (1776). Voyage a la Nouvelle Guinee: dans lequel on trouve la } \\
\text { description des lieux, des observations physiques \& morales, \& des details } \\
\text { relatifs a l'histoire naturelle dans le regne animal \& le regne vegetal... Paris: } \\
\text { Chez Ruault, Librair, rue de la Harpe. } \\
\text { Binding: ca. early 19th century full calf, gilt. }\end{array}$ & Binder's label, verso FFEP: Com.te de caumont | No. 1 Frith Street. Soho Square. \\
\hline $070-071$ & $\begin{array}{l}\text { Stewart, C.S. (1832). A visit to the South Seas, in the United States' ship } \\
\text { Vincennes, during the years } 1829 \text { and 1830: including scenes in Brazil, Peru, }\end{array}$ & AUCL bequest label, front pastedown, vol. 1-2: Alfred Kidd. \\
\hline
\end{tabular}




\begin{tabular}{|c|c|c|}
\hline Record & Title details & Provenance evidence (stage one sample) \\
\hline & $\begin{array}{l}\text { Manilla, the Cape of Good Hope, and St. Helena, } 2 \text { vols. London: Colburn } \\
\text { and Bentley. } \\
\text { Binding: contemporary paper boards, rebacked. }\end{array}$ & Accession: 8216-8217. \\
\hline $072-073$ & $\begin{array}{l}\text { Stewart, C.S. (1833). A visit to the South Seas, in the United States ship } \\
\text { Vincennes, during the years } 1829 \text { and } 1830 \text { : including notices of Brazil, Peru, } \\
\text { Manilla, the Cape of Good Hope, and St. Helena, } 2 \text { vols. New York: P. Haven. } \\
\text { Binding: contemporary cloth. }\end{array}$ & $\begin{array}{l}\text { Pictorial bookplate, front pastedown, vol. 1-2: Ex libris | A L Chappell. } \\
\text { [After this shortened to Pictorial bookplate: A L Chappell.] }\end{array}$ \\
\hline $074-076$ & $\begin{array}{l}\text { Turnbull, J. (1805). A voyage round the world in the years 1800, 1801, 1802, } \\
1803 \text { and 1804: in which the author visited the principal islands in the } \\
\text { Pacific Ocean, and the settlements of Port Jackson and Norfolk Island. } \\
\text { London: Phillips. } \\
\text { Binding: 20th century quarter leather and cloth boards. }\end{array}$ & $\begin{array}{l}\text { UoAL gift label, verso FFEP: The gift of [MSS: Mr George Fowlds] to the University } \\
\text { of Auckland Library. }\end{array}$ \\
\hline 077-078 & $\begin{array}{l}\text { Walpole, F. (1849). Four years in the Pacific in Her Majesty's Ship } \\
\text { "Collingwood", from } 1844 \text { to } 1848,2 \text { vols. London: R. Bentley. } \\
\text { Binding: contemporary cloth boards. }\end{array}$ & $\begin{array}{l}\text { Pictorial bookplate, front pastedown, vol. 1-2: A L Chappell. } \\
\text { Pencil inscription, ca. 20th century, front pastedown, vol. 1: Downes }\end{array}$ \\
\hline 084 & $\begin{array}{l}\text { Wilkes, C. (1845). Narrative of the United States Exploring Expedition, } \\
\text { during the years 1838, 1840, 1841, 1842. Condensed and abridged [ed.]. } \\
\text { London: Whittaker and Co. } \\
\text { Binding: 20th century cloth boards. }\end{array}$ & $\begin{array}{l}\text { AUCL bequest: Alfred Kidd. } \\
\text { Accession: } 8221 .\end{array}$ \\
\hline 088 & $\begin{array}{l}\text { Delano, A. (1817). A narrative of voyages and travels in the northern and } \\
\text { southern hemispheres: comprising three voyages round the world together } \\
\text { with a voyage of survey and discovery, in the Pacific Ocean and Oriental } \\
\text { Islands. Boston: Printed by E.G. House for the author. } \\
\text { Binding: paper boards, paper label, uncut edges. }\end{array}$ & $\begin{array}{l}\text { Ink inscription, ca. 19th century, title page: Charles I Kip } \\
\text { Annotations in text block in possibly the same hand. }\end{array}$ \\
\hline 099-101 & $\begin{array}{l}\text { Kotzebue, O. von. (1821). A voyage of discovery, into the South Sea and } \\
\text { Beering's Straits, for the purpose of exploring a north-east passage: } \\
\text { undertaken in the years 1815-1818, at the expense of His Highness..., } 3 \text { vols. } \\
\text { London: Longman, Hurst, Rees, Orme, and Brown. Copy } 1 . \\
\text { Binding: contemporary pasteboards, paper label, uncut edges. }\end{array}$ & $\begin{array}{l}\text { AUCL bequest label, front pastedown, vol. 1-3: Alfred Kidd. } \\
\text { Accession: 8218-8220. } \\
\text { Pencil markings, front pastedown: 72/. } \\
\text { Pencil markings, FFEP: } £ 7.10 \\
\text { Binder’s label, front pastedown, vol. 1-3: G. Peck, | Bookbinder }\end{array}$ \\
\hline $102-104$ & Kotzebue, O. von. (1821). A voyage of discovery, into the South Sea and & Pictorial bookplate, front pastedown, vol. 1-3: A L Chappell. \\
\hline
\end{tabular}




\begin{tabular}{|c|c|c|}
\hline Record & Title details & Provenance evidence (stage one sample) \\
\hline & $\begin{array}{l}\text { Beering's Straits, for the purpose of exploring a north-east passage: } \\
\text { undertaken in the years } 1815-1818 \text {, at the expense of His Highness..., } 3 \text { vols. } \\
\text { London: Longman, Hurst, Rees, Orme, and Brown. Copy } 2 . \\
\text { Binding: contemporary full calf, rebacked, gilt. }\end{array}$ & In same hand under tipped-in bibliographical details: Francis Edwards June 1912. \\
\hline 108 & $\begin{array}{l}\text { Byron, J. (1767). A voyage round the world in His Majesty's ship the } \\
\text { Dolphin: commanded by the Honourable Commodore Byron: in which is } \\
\text { contained a faithful account of the several places, people, plants, animals, } \\
\text { \&c. seen on the voyage..., 2nd ed. London: Printed for J. Newbery. } \\
\text { Binding: 20th century cloth. }\end{array}$ & $\begin{array}{l}\text { Ink inscription, ca. 18th-19th century, title page: } F \text { [? or J?] Horner. } \\
\text { Effaced inscription, recto frontispiece. } \\
\text { Pencil marking, front pastedown: } £ 45 \text { - }\end{array}$ \\
\hline 109 & $\begin{array}{l}\text { Bays, P. (1831). Narrative of the wreck of the Minerva, whaler of Port } \\
\text { Jackson, New South Wales, on Nicholson's shoal, } 24 \text { S. } 179 \text { W.:... Cambridge } \\
\text { [England]: B.Bridges. } \\
\text { Binding: Paper boards, marbled paper spine, paper spine label. Some } \\
\text { pages unopened. }\end{array}$ & $\begin{array}{l}\text { Pictorial-armorial bookplate, front pastedown: } \\
\text { Constans fidei | James Edge-Partington | CP No [Mss: 37?] } \\
\text { Pictorial bookplate, FFEP: Ex libris | Nancye Kent Perry | [MSS]: } 17 \text { May } 1973 \\
\text { [MSS]: } 3224\end{array}$ \\
\hline $110-111$ & $\begin{array}{l}\text { Beechey, F.W. (1831). Narrative of a voyage to the Pacific and Beering's } \\
\text { Strait, to co-operate with the Polar expeditions: performed in His Majesty's } \\
\text { Ship Blossom in the years } 1825,26,27,28,2 \text { vols. London: H. Colburn and } \\
\text { R. Bentley. } \\
\text { Binding: contemporary paste boards, paper spine label. }\end{array}$ & $\begin{array}{l}\text { Armorial bookplate, front pastedown, vol. 1-2: Virtute et opera | Thos. Fraser Duff } \\
\text { [Thomas Fraser Duff, born 1830, died 1877, of Woodcote House and Checkendon } \\
\text { Court, Oxfordshire, England]. } \\
\text { Pencil marking, front pastedown, vol. 1: } £ 20 \text {. }\end{array}$ \\
\hline 112 & $\begin{array}{l}\text { Clark, J.G. (1847). Lights and shadows of sailor life: as exemplified in fifteen } \\
\text { years' experience, including the more thrilling events of the U.S. Exploring } \\
\text { Expedition... Boston: J. Putnam. } \\
\text { Binding: contemporary cloth, gilt. }\end{array}$ & Ink inscription, front pastedown: D. Waldowski \\
\hline 117-119 & $\begin{array}{l}\text { La Billardiere, J-J. H. de. (1802). An account of a voyage in search of La } \\
\text { Pérouse: undertaken by order of the Constituent Assembly of France, and } \\
\text { performed in the years 1791, 1792, and 1793, in the Recherche and } \\
\text { Esperance, ships of war..., } 3 \text { vols. London: Printed for B. Uphill. } \\
\text { Binding: ca. late 19th century half calf and marbled boards. }\end{array}$ & $\begin{array}{l}\text { Pictorial bookplate, front pastedowns vol. 1-3: Tamdiu discendum est quamdiu } \\
\text { vivas | Ex libris | Joseph M Gleason } \\
\text { [Monsignor Joseph M. Gleason (1869-1942), Californian Catholic priest and book } \\
\text { collector]. } \\
\text { Stamp, verso title page, vol. 1-2: } 64759 \text {. Vol 3: } 64761 \\
\text { Pencil markings, verso FFEP vol. 2: A/176101 | \$4750.00 incl. GST | } 3 \text { vols }\end{array}$ \\
\hline $120-122$ & La Billardiere, J-J H. de. (1811). Relation du voyage a la recherche de La & Bibliographic description, laid in, by twenty-first century Netherlands bookseller \\
\hline
\end{tabular}




\begin{tabular}{|c|c|c|}
\hline Record & Title details & Provenance evidence (stage one sample) \\
\hline & $\begin{array}{l}\text { Perouse..., } 3 \text { vols. Paris: Chez F. Schoell. } \\
\text { Binding: contemporary half leather and marbled boards, gilt. }\end{array}$ & Antiquariaat. \\
\hline 123 & $\begin{array}{l}\text { Sparks, J. (1828). The life of John Ledyard, the American traveller: } \\
\text { comprising selections from his journals and correspondence. } \\
\text { Cambridge [Mass.]: Hilliard and Brown; New York: G. \& C. Carvill... } \\
\text { Binding: ca. 20th-21st century cloth, gilt. }\end{array}$ & $\begin{array}{l}\text { Bibliographic description laid in and twenty-first century bookseller's label, front } \\
\text { pastedown: Gaston Renard Pty. Ltd [Australia]. } \\
\text { Ink inscription, front pastedown, mostly erased: }[\ldots \mid \text { from his friend ... | .. 182.?] }\end{array}$ \\
\hline 124 & $\begin{array}{l}\text { Sparks, J. (1834). Travels and adventures of John Ledyard: comprising his } \\
\text { voyage with Capt. Cook's third and last expedition, his journey on foot } 1300 \\
\text { miles round the Gulf of Bothnia to St. Petersburgh ... London: Published for } \\
\text { Henry Colburn by R. Bentley. } \\
\text { Binding: 20th century half leather and cloth boards, gilt. }\end{array}$ & $\begin{array}{l}\text { Pictorial bookplate, front pastedown: Ex libris | Bjarne Kroepelien } \\
\text { [Bjarne Gran Teriieroo Kroepelien (1890-1966): Norwegian bibliographer of works } \\
\text { on Polynesia ]. } \\
\text { Ink annotation, ca. } 20 \text { th century, title page: Jared Sparks | 1st. Edition similar in } \\
\text { every respect but with different title page. } 1828 . \\
\text { Pencil markings, verso FFEP: } £ 250 \text { [struck through] |\#19764 | \$1200 | } \\
\text { Pencil markings [different hand]: } 32140 \mid \text { OBT/-. }\end{array}$ \\
\hline 125 & $\begin{array}{l}\text { Morrell, A. (1833). Narrative of a voyage to the Ethiopic and South Atlantic } \\
\text { Ocean, Indian Ocean, Chinese Sea, North and South Pacific Ocean, in the } \\
\text { years 1829, 1830, 1831. New-York: J. \& J. Harper. } \\
\text { Binding: ca. contemporary cloth. }\end{array}$ & $\begin{array}{l}\text { Pencil inscription, ca. 20th century, verso FFEP: Mrs [...?] Weston [...?] | Augusta | } \\
\text { Maine } \\
\text { Ink inscription, FFEP and title page: Hannah E North | Duanesburgh | New York } \\
\text { Label, front pastedown: Vilhjalmur Stefansson | } 27 \text { West 44th Street | New York } \\
\text { City } \\
\text { [Vilhjalmur Stefansson (1879-1962), Canadian arctic explorer and ethnologist]. }\end{array}$ \\
\hline 126 & $\begin{array}{l}\text { Morrell, B. (1832). A narrative of four voyages: to the South Sea, North and } \\
\text { South Pacific Ocean, Chinese sea, Ethiopic and southern Atlantic Ocean, } \\
\text { Indian and Antarctic Ocean: from the year } 1822 \text { to } 1831 \text {... New York: J. \& J. } \\
\text { Harper. } \\
\text { Binding: } 19 \text { th century calf and marbled boards, gilt. Gilt armorial stamp, } \\
\text { spine and front board. }\end{array}$ & $\begin{array}{l}\text { Gilt armorial stamp, spine and front board: General Assembly Library New } \\
\text { Zealand. } \\
\text { Label, front pastedown: General Assembly | Library, N.Z. | Number: [MSS: 55177] } \\
\text { | Class: [MSS: 910.4] | Loc.: [MSS:M873]. Overstamped: Reference. Overstamped: } \\
\text { Withdrawn } \\
\text { Ink marking, front pastedown: Beth | 28/- | 252/1 [in a circle] [Possibly for }\end{array}$ \\
\hline
\end{tabular}




\begin{tabular}{|c|c|c|}
\hline Record & Title details & Provenance evidence (stage one sample) \\
\hline & & Bethune's] \\
\hline 127 & $\begin{array}{l}\text { Murray, H. (1827). Adventures of British seamen in the southern ocean, } \\
\text { displaying the striking contrasts which the human character exhibits in an } \\
\text { uncivilized state. Edinburgh: Printed for Constable. Copy } 1 . \\
\text { Binding: contemporary leather. }\end{array}$ & AUCL presentation label, front pastedown: George Fowlds. \\
\hline $129-131$ & $\begin{array}{l}\text { Péron,F., Freycinet, L.C.D. de, Lesueur, C.A., \& Petit, N.M. (1807-16). } \\
\text { Voyage de découvertes aux terres Australes, exécuté par ordre de Sa } \\
\text { Majesté l'empereur et roi, sur les corvettes le Géographe, le Naturaliste, et } \\
\text { la goëlette le Casuarina, pendent les années 1800, 1801, 1802, } 1803 \text { et } \\
\text { 1804..., } 3 \text { vols. Paris: De l'Imprimerie impériale. } \\
\text { Binding: 19th century full leather, gilt. }\end{array}$ & $\begin{array}{l}\text { Pictorial bookplate, front pastedown, in vol. 1-2: Hollycombe 1805-1892 | J.C. } \\
\text { Hawkshaw } \\
\text { [John Clarke Hawkshaw, British civil engineer, born in Manchester, England in } \\
\text { 1841, died 1921]. }\end{array}$ \\
\hline $135-139$ & $\begin{array}{l}\text { Burney, J. (1803-1817). A chronological history of the discoveries in the } \\
\text { South Sea or Pacific Ocean, } 5 \text { vols. London: Printed by Luke Hansard... and } \\
\text { sold by G. and W. Nicol... [etc]. } \\
\text { Binding: ca. 20th century half calf and marbled boards, gilt. }\end{array}$ & $\begin{array}{l}\text { Label, front pastedown and title page, vol. 1-5, with blind armorial crest stamp and } \\
\text { text: Loyal en toute Seale. | South Sea Library | of Alvin and Ethel Seale | San } \\
\text { Francisco, } 1936 \text { | No. [MSS704-708] } \\
\text { Blind stamp [same as label], FFEP and title page, vol. 1-5: Blind armorial crest } \\
\text { stamp on label: Loyal en toute Seale. } \\
\text { Ink inscription, FFEP, vol. 1-5: Alvin Seale. Nov. 20. 1935. | A gift from my sweet } \\
\text { wife | Ethel Alice Seale. } \\
\text { Label, front pastedown, vol. 1: R.D.P. [David Parsons]. } \\
\text { Minor pencil annotations to some textblocks. }\end{array}$ \\
\hline 142 & $\begin{array}{l}\text { Behrens, K.F. (1739). Histoire de l'expedition de trois vaisseaux, envoyes par } \\
\text { la Compagnie des Indes Occidentales des Provinces-Unies, aux Terres } \\
\text { Australes en MDCCXXI. A la Haye: Aux Depens de la Compagnie. } \\
\text { Binding: blind-tooled full leather, armorial crest front and rear boards. }\end{array}$ & $\begin{array}{l}\text { Blind-tooled armorial crest, front and rear boards. } \\
\text { Ink inscription, ca. 18th century, front fly-leaf: Louise Christiane Princesse I } \\
\text { Palatine de Birckenfeldt } \\
\text { Label, front pastedown: R.D.P. [David Parsons]. } \\
\text { Pencil marking, short title page: 504/922. }\end{array}$ \\
\hline 143 & $\begin{array}{l}\text { Coulter, J. (1845). Adventures in the Pacific: with observations of the } \\
\text { natural productions, manners and customs of the natives of the various }\end{array}$ & Pictorial bookplate, front pastedown: A L Chappell. \\
\hline
\end{tabular}




\begin{tabular}{|c|c|c|}
\hline Record & Title details & Provenance evidence (stage one sample) \\
\hline & $\begin{array}{l}\text { islands: together with remarks on missionaries, British and other residents, } \\
\text { etc. etc. Coulter. Dublin: William Curry. } \\
\text { Binding: contemporary cloth. }\end{array}$ & \\
\hline $146-147$ & $\begin{array}{l}\text { Freville, A.F.J. (1774). Histoire des nouvelles decouvertes faites dans la Mer } \\
\text { du Sud en 1767, 1768, } 1769 \text { \& } 1770 . . .2 \text { vols. A Paris: Chez de Hansy le } \\
\text { jeune. } \\
\text { Binding: contemporary French mottled calf, gilt. }\end{array}$ & $\begin{array}{l}\text { Anonymous armorial bookplate, front pastedown vol. 1-2: motto: He plaa diu } \\
\text { t'ayudy. } \\
\text { [Possibly for a member of the French Laussat family]. } \\
\text { Label, front pastedown, vol. 1: R.D.P. [David Parsons]. } \\
\text { Label, FFEP, vol. 1: } 2002 \text {, vol. 2: } 2003 \\
\text { Ink marking, verso FFEP, vol. } 1: 3 \text { vol. in } 8^{\circ} \text {..... 12\# | hist. | Sect. } 2 \text { [illegible] | v1. } \\
\text { Voyag et R[illegible] } \\
\text { Pencil marking, short title page, vol. } 1: 504 / 845 \text { | } 2 \text { vols }\end{array}$ \\
\hline 148 & $\begin{array}{l}\text { Goodridge, C.M. (1841). Narrative of a voyage to the South Seas, and the } \\
\text { shipwreck of the Princess of Wales cutter: with an account of two years } \\
\text { residence on an uninhabited island. London: W.C. Featherstone. } \\
\text { Binding: 20th century cloth. }\end{array}$ & $\begin{array}{l}\text { UoAL replacement label, fly-leaf [volume rebound]: The gift of [MSS: Mr. Alfred } \\
\text { Kidd] to the University of Auckland Library. } \\
\text { Accession: } 8245 \text {. }\end{array}$ \\
\hline 149 & $\begin{array}{l}\text { Goodridge, C.M. (1843). Narrative of a voyage to the South Seas, and the } \\
\text { shipwreck of the Princess of Wales cutter: with an account of two years } \\
\text { residence on an uninhabited island. Exeter: Featherstone. } \\
\text { Binding: 20th century cloth. }\end{array}$ & $\begin{array}{l}\text { UoAL replacement label, fly-leaf [volume rebound]: The gift of [MSS: Mr. J.C. } \\
\text { Entrican] to the University of Auckland Library. }\end{array}$ \\
\hline $152-153$ & $\begin{array}{l}\text { Moerenhout, J. A. (1837). Voyages aux îles du Grand océan: contenant des } \\
\text { documens nouveaux sur la géographie physique et politique, la langue, la } \\
\text { littérature, la religion, les mœurs, les usages et les coutumes de leurs } \\
\text { habitans ... } 2 \text { vols. Paris: A. Bertrand. } \\
\text { Binding: ca. 19th century quarter leather and marbled boards, gilt. }\end{array}$ & $\begin{array}{l}\text { Label, front pastedown, vol. 1: R.D.P. [David Parsons]. } \\
\text { Pencil marking, vol. 1: } 2 \text { volumes | 50x/90s | } 2 \text { vols. [... ?] } 2000 \text { | [..97] }\end{array}$ \\
\hline 155 & $\begin{array}{l}\text { Porter, D. (1823). A voyage in the South Seas, in the years } 1812,1813, \text { and } \\
\text { 1814: with particular details of the Gallipagos and Washington Islands. } \\
\text { London: Sir R. Phillips. } \\
\text { Binding: 20th century cloth. }\end{array}$ & Pictorial bookplate, front pastedown: A L Chappell. \\
\hline 156 & Shoberl, F. (1824). The world in miniature. South Sea Islands: being a & Bookseller's label, front pastedown: Berkelouw Bookdealers Sydney \\
\hline
\end{tabular}




\begin{tabular}{|c|c|c|}
\hline Record & Title details & Provenance evidence (stage one sample) \\
\hline & $\begin{array}{l}\text { description of the manners, customs, character, religion, and state of } \\
\text { society among the various tribes scattered over the great ocean called the } \\
\text { Pacific or the South Sea. London: Ackermann. } \\
\text { Binding: ca. 19th century cloth. }\end{array}$ & \\
\hline 157 & $\begin{array}{l}\text { (1831). A voyage through the islands of the Pacific Ocean / compiled from } \\
\text { the most authentic and recent authorities. London: Printed for C.J.G. \& F. } \\
\text { Rivington. } \\
\text { Binding: } \mathrm{ca} .19^{\text {th }} \text { century quarter leather and marbled boards, gilt. }\end{array}$ & $\begin{array}{l}\text { Ink inscription, front pastedown: James John Peacock | Christmas } 1862 \\
\text { Binder's stamp, front pastedown: F. Remnant, binder, | } 9 \text { Lovell's Court, | } \\
\text { Paternoster Row. }\end{array}$ \\
\hline 161 & $\begin{array}{l}\text { Earl, G.W. (1837). The eastern seas, or, Voyages and adventures in the } \\
\text { Indian Archipelago in 1832-33-34: comprising a tour of the island of Java, } \\
\text { visits to Borneo, the Malay Peninsula, Siam, etc... London: Wm. H. Allen. } \\
\text { Binding: ca. } 20^{\text {th }} \text { century cloth. }\end{array}$ & $\begin{array}{l}\text { AUCL bequest label, front pastedown: Alfred Kidd. } \\
\text { Accession: } 8224 \text {. }\end{array}$ \\
\hline 164 & $\begin{array}{l}\text { Kolff, D.H. (1840). Voyages of the Dutch brig of war Dourga: through the } \\
\text { southern and little-known parts of the Moluccan archipelago and along the } \\
\text { previously unknown southern coast of New Guinea performed during the } \\
\text { years } 1825 \text { and } 1826 \text {. London: Madden. } \\
\text { Binding: contemporary cloth. }\end{array}$ & Pictorial bookplate, front pastedown: A L Chappell. \\
\hline 166 & $\begin{array}{l}\text { Forrest, T. (1779). A voyage to New Guinea, and the Moluccas, from } \\
\text { Balambangan: including an account of Magindano, Sooloo, and other } \\
\text { islands... Dublin: Printed for Price, W. and Whitstone, H. [\& others]. } \\
\text { Binding: Full leather, rebacked. }\end{array}$ & $\begin{array}{l}\text { Pictorial bookplate, fly-leaf: A L Chappell. } \\
\text { Pencil inscription, FFEP: Mr Matthew Anderson. } \\
\text { Ink and pencil sketches of a head on FFEP. } \\
\text { Ink inscription, dedication and introduction pages: John Stewart | Wilmont. } \\
\text { Pencil inscriptions, plates directions page: Mr Alexander Anderson | Lagan Village } \\
\text { | Belfast. } \\
\text { Pencil inscription, same page: Mr Matthew Anderson. } \\
\text { Ink inscription, same page: Mr Wm Broun [?], Coffiled [?] Castle [... ? ... ?] } \\
\text { Ink sketch, RFEP: Sailing ship. [Similar ink to that used for Stewart.] }\end{array}$ \\
\hline 167 & Forrest, T. (1780). A voyage to New Guinea and the Moluccas, from & AUCL bequest label, FFEP: Alfred Kidd. \\
\hline
\end{tabular}




\begin{tabular}{|c|c|c|}
\hline & Title details & Provenance evidence (stage one sample) \\
\hline & $\begin{array}{l}\text { Balambangan: including an account of Magindano, Sooloo, and other } \\
\text { islands ..., 2nd ed. London: Printed by G. Scott. } \\
\text { Binding: ca. 19th century half calf and marbled boards. }\end{array}$ & $\begin{array}{l}\text { Accession: } 8422 . \\
\text { Inscription, ca. 18th-19th century, recto frontispiece: George Bidwood }\end{array}$ \\
\hline $168-169$ & $\begin{array}{l}\text { Angas, G.F. (1847). Savage life and scenes in Australia and New Zealand: } \\
\text { being an artist's impressions of countries and people at the antipodes..., } \\
\text { 2nd. ed. } 2 \text { vols. London: Smith, Elder and Co. Copy } 1 . \\
\text { Binding: } 20 \text { th century half calf and cloth boards. }\end{array}$ & $\begin{array}{l}\text { AUCL presentation label, front pastedown, vol. 1-2: This book was presented | to } \\
\text { the Library of the | [blank] | by E. Earle Vaile. [Plate design by Hilda Wiseman]. } \\
\text { Pencil inscription, fly-leaf, Vol. 1: E. E. Vaile | Waiotapu | Auckland, N.Z. | Oct/24 } \\
\text { Binder's stamp, verso FFEP, vol. 1-2: Henry Young \& Sons Ltd Liverpool }\end{array}$ \\
\hline $170-171$ & $\begin{array}{l}\text { Angas, G.F. (1847). Savage life and scenes in Australia and New Zealand: } \\
\text { being an artist's impressions of countries and people at the antipodes..., } \\
\text { 2nd. Ed. } 2 \text { vols. London: Smith, Elder and Co. Copy } 2 . \\
\text { Binding: contemporary cloth boards, rebacked. }\end{array}$ & $\begin{array}{l}\text { AUCL bequest label, front pastedown, vol. 1-2: Alfred Kidd. } \\
\text { Accession. 8261-8262. }\end{array}$ \\
\hline 173 & $\begin{array}{l}\text { Backhouse, J. (1843). A narrative of a visit to the Australian colonies. } \\
\text { London: Hamilton, Adams, and Co. } \\
\text { Binding: 20th century rebind. }\end{array}$ & $\begin{array}{l}\text { AUCL bequest label, front pastedown: Alfred Kidd. } \\
\text { Accession: } 8286 .\end{array}$ \\
\hline 174 & $\begin{array}{l}\text { Jameson, R.G. (1842). New Zealand, South Australia, and New South Wales: } \\
\text { a record of recent travels in these colonies, with especial reference to } \\
\text { emigration and the advantageous employment of labour and capital. } \\
\text { London: Smith, Elder. Copy } 1 . \\
\text { Binding: } 20 \text { th century quarter leather and cloth boards. }\end{array}$ & $\begin{array}{l}\text { UoAL gift label, recto frontispiece: The gift of Mr. Alfred Kidd to the University of } \\
\text { Auckland Library [replacement label, Library rebind]. } \\
\text { Accession: } 8269 . \\
\text { Pencil inscription, title page: A Kidd. } \\
\text { Ink inscription, ca. 19th century, title page: Walter Booth }\end{array}$ \\
\hline 175 & $\begin{array}{l}\text { Jameson, R.G. (1842). New Zealand, South Australia, and New South Wales: } \\
\text { a record of recent travels in these colonies, with especial reference to } \\
\text { emigration and the advantageous employment of labour and capital. } \\
\text { London: Smith, Elder. Copy } 2 \text {. } \\
\text { Binding: } 20 \text { th century half leather and cloth boards. }\end{array}$ & $\begin{array}{l}\text { UoAL label, front pastedown: The University of Auckland | Library | From the } \\
\text { Collection of | Allan and Jess North | Te Whaiti, Urewera. } \\
\text { [After this shortened to UoAL label: Allan and Jess North.] } \\
\text { Ink marking, ca. late 19th or early 20th century, tipped-in leaf: transcript of } \\
\text { Anthony Trollope piece from the Liverpool Mercury, Saturday, November 6, } 1875 .\end{array}$ \\
\hline 176 & $\begin{array}{l}\text { Oxley, J. (1820). Journals of two expeditions into the interior of New South } \\
\text { Wales: undertaken by order of the British Government in the years 1817-18. }\end{array}$ & AUCL bequest label, front pastedown: Alfred Kidd. \\
\hline
\end{tabular}




\begin{tabular}{|c|c|c|}
\hline Record & Title details & Provenance evidence (stage one sample) \\
\hline & $\begin{array}{l}\text { London: John Murray. } \\
\text { Binding: ca. contemporary leather and marbled boards. }\end{array}$ & $\begin{array}{l}\text { Accession: } 8421 . \\
\text { Pencil marking, front pastedown: [illegible]. Pencil: R/R [illegible], Pencil: } 33 . \\
\text { Pencil: Australia | Oxley. } \\
\text { Pencil marking, FFEP: £5.5 }\end{array}$ \\
\hline 177 & $\begin{array}{l}\text { Angas, G.F. (1847). South Australia illustrated. London: Thomas M'lean. } \\
\text { Binding: cloth case, leather boards. }\end{array}$ & $\begin{array}{l}\text { AUCL bequest label, front pastedown: Alfred Kidd. } \\
\text { Accession: } 8424 \text {. }\end{array}$ \\
\hline 178 & $\begin{array}{l}\text { Angas, G.F. (1847). The New Zealanders illustrated. London: Thomas } \\
\text { M'lean. Copy } 1 . \\
\text { Binding: cloth case, leather boards. }\end{array}$ & $\begin{array}{l}\text { AUCL bequest label, front pastedown: Alfred Kidd. } \\
\text { Accession: } 8425 . \\
\text { Bookseller's label, rear pastedown: Matthews | and | Brooke | Booksellers | } \\
\text { Bradford }\end{array}$ \\
\hline 179 & $\begin{array}{l}\text { Angas, G.F. (1847). The New Zealanders illustrated. London: Thomas } \\
\text { M'lean. Copy } 2 . \\
\text { Binding: Half leather and cloth boards. }\end{array}$ & $\begin{array}{l}\text { AUCL presentation label, front pastedown: George Fowlds. } \\
\text { Pencil marking, verso FFEP: } £ 12 \text {. Pencil: } £ 14\end{array}$ \\
\hline 180 & $\begin{array}{l}\text { Bidwill, J.C. (1841). Rambles in New Zealand. London: London: W.S. Orr ; } \\
\text { Exeter: J. Fitze, } \\
\text { Binding: 20th century half calf and cloth, gilt; over wrappers. }\end{array}$ & $\begin{array}{l}\text { Pictorial-armorial bookplate, front pastedown: Constans fideo | CP | James Edge } \\
\text { Partington | No [MSS: L5] }\end{array}$ \\
\hline 181 & $\begin{array}{l}\text { Brees, S.C. (1849). Pictorial illustrations of New Zealand. London: J. } \\
\text { Williams. Copy } 1 . \\
\text { Binding: contemporary cloth. }\end{array}$ & $\begin{array}{l}\text { AUCL presentation label, FFEP: George Fowlds. } \\
\text { Bookseller's label, front pastedown: Dymock's | Book Arcade | } 428 \text { George-st., } \\
\text { Sydney. } \\
\text { Pencil marking, title page: } 1847 \text { ? (Seems identical with } 1847 \text { (1st eds.) of Public } \\
\text { Library. c/f Hocken, p. } 132\end{array}$ \\
\hline 184 & $\begin{array}{l}\text { Brodie, W. (1845). Remarks on the past and present state of New Zealand, } \\
\text { its government, capabilities and prospects... London England: Whittaker } \\
\text { and Co. Copy } 1 . \\
\text { Binding: contemporary embossed cloth, rebacked. }\end{array}$ & $\begin{array}{l}\text { AUCL bequest label, front pastedown: Alfred Kidd. } \\
\text { Accession: } 8165 \text {. }\end{array}$ \\
\hline 185 & $\begin{array}{l}\text { Brodie, W. (1845). Remarks on the past and present state of New Zealand, } \\
\text { its government, capabilities and prospects... London England: Whittaker }\end{array}$ & AUCL presentation label, rear pastedown: George Fowlds. \\
\hline
\end{tabular}




\begin{tabular}{|c|c|c|}
\hline Record & Title details & Provenance evidence (stage one sample) \\
\hline & $\begin{array}{l}\text { and Co. Copy } 2 . \\
\text { Binding: contemporary embossed cloth, rebacked. }\end{array}$ & Accession: 16,913 \\
\hline 186 & $\begin{array}{l}\text { Burford, R. (1838). Description of a view of the Bay of Islands, New Zealand, } \\
\text { and the surrounding country, now exhibiting at the Panorama, Leicester } \\
\text { Square... London: Printed by G. Nichols. } \\
\text { Binding: ca. contemporary half calf and marbled boards. }\end{array}$ & $\begin{array}{l}\text { AUCL bequest label, front pastedown: Alfred Kidd. } \\
\text { Accession: } 8298 . \\
\text { Pencil inscription, verso title page: A Kidd. } \\
\text { Ink inscription, ca. 19th century, title page: R Luggate }\end{array}$ \\
\hline 187 & $\begin{array}{l}\text { Chapman, H.S. (1843). The New Zealand portfolio: embracing a series of } \\
\text { papers on subjects of importance to the colonists... London: Smith, Elder. } \\
\text { Binding: contemporary half calf and marbled boards. }\end{array}$ & $\begin{array}{l}\text { AUCL bequest label, front pastedown: Alfred Kidd. } \\
\text { Accession: } 8164 \text {. }\end{array}$ \\
\hline 188 & $\begin{array}{l}\text { Craik, G.L. (1830). The New Zealanders. London: Knight. Copy } 1 . \\
\text { Binding: ca. contemporary half leather and marbled boards. }\end{array}$ & $\begin{array}{l}\text { AUCL bequest label, front pastedown: Alfred Kidd. } \\
\text { Accession: } 8388 \text {. }\end{array}$ \\
\hline 189 & $\begin{array}{l}\text { Craik, G.L. (1830). The New Zealanders. London: Knight. Copy } 2 . \\
\text { Binding: 20th century quarter leather and marbled boards. }\end{array}$ & $\begin{array}{l}\text { AUCL replacement presentation label: George Fowlds. } \\
\text { Ink inscription, ca. 19th-20th century, title page: R.M. Tolhurst }\end{array}$ \\
\hline 191 & $\begin{array}{l}\text { Craik, G.L. (1830). The New Zealanders. London: Knight. Copy } 4 . \\
\text { Binding: ca. contemporary half calf and marbled boards. }\end{array}$ & Ink inscription, ca. 19th-20th century, fly-leaf: [...? edR] Edwd Wood \\
\hline 193 & $\begin{array}{l}\text { Craik, G.L. (1830). The New Zealanders.London: Knight. Copy } 6 . \\
\text { Binding: 20th century cloth. }\end{array}$ & UoAL label, front pastedown: Allan and Jess North. \\
\hline 194 & $\begin{array}{l}\text { Cruise, R.A. (1823). Journal of a ten months' residence in New Zealand. } \\
\text { London: Longman, Hurst, Rees, Orme and Brown. Copy } 1 . \\
\text { Binding: 20th century cloth. }\end{array}$ & $\begin{array}{l}\text { AUCL bequest label, front pastedown: Alfred Kidd. } \\
\text { Accession: } 8300 \text {. } \\
\text { Pencil marking, recto frontispiece: } £ 3.10\end{array}$ \\
\hline 195 & $\begin{array}{l}\text { Cruise, R.A. (1823). Journal of a ten months' residence in New Zealand. } \\
\text { London: Longman, Hurst, Rees, Orme and Brown. Copy } 2 . \\
\text { Binding: paper boards. }\end{array}$ & $\begin{array}{l}\text { AUCL presentation label: George Fowlds. } \\
\text { Pencil marking, front pastedown: 20/- } \\
\text { Ink inscription, title page: Dr Brown [?] }\end{array}$ \\
\hline 196 & $\begin{array}{l}\text { Cruise, R.A. (1823). Journal of a ten months' residence in New Zealand. } \\
\text { London: Longman, Hurst, Rees, Orme and Brown. Copy } 3 .\end{array}$ & UoAL replacement gift label, recto frontispiece: Mr George Fowlds. \\
\hline
\end{tabular}




\begin{tabular}{|c|c|c|}
\hline Record & Title details & Provenance evidence (stage one sample) \\
\hline & Binding: 20th century leather and cloth boards. & $\begin{array}{l}\text { Ink stamp [smudged], title and other pages: Australian Subscription Library } 1826 \\
\text { Ink stamp, title and other pages: Free Public Library Sydney New South Wales } \\
\text { Blind stamp, title and other pages: Sold by the authority of the Trustees of the } \\
\text { Public Library of New South Wales. [Overwritten in ink: Henry C. L. Anderson. } \\
\text { Principal Librarian. }\end{array}$ \\
\hline 197 & $\begin{array}{l}\text { Cruise, R.A. (1824). Journal of a ten months' residence in New Zealand, 2nd } \\
\text { ed. London: Longman, Hurst, Rees, Orme and Brown. Copy } 1 . \\
\text { Binding: contemporary half calf and marbled boards. }\end{array}$ & $\begin{array}{l}\text { AUCL bequest label, front pastedown: Alfred Kidd. } \\
\text { Accession: } 8299 . \\
\text { Ink marking, fly-leaf: F. III. } 24 \text {. }\end{array}$ \\
\hline 198 & $\begin{array}{l}\text { Cruise, R.A. (1824). Journal of a ten months' residence in New Zealand, 2nd } \\
\text { ed. London: Longman, Hurst, Rees, Orme and Brown. Copy } 2 . \\
\text { Binding: contemporary cloth boards. }\end{array}$ & $\begin{array}{l}\text { UoAL label, front pastedown: Allan and Jess North. } \\
\text { Ink inscription, front pastedown: Allan North, | Te Whaiti, | } 14.2 .53 \\
\text { Pencil inscription, 20th century, short title page: F.J. Halse. } \\
\text { Pencil marking: Sold by Bethune \& Co | } 23 \text { March } 1934 \text { | f4.10 | [illegible] } 1949 \\
\text { up to [illegible] | at Bethune [in Halse's hand]. } \\
\text { Pencil annotations on 20th century map tipped in, rear pastedown: events and } \\
\text { dates, degrees and times. }\end{array}$ \\
\hline $199-200$ & $\begin{array}{l}\text { Dieffenbach, E. (1843). Travels in New Zealand, with contributions to the } \\
\text { geography, geology, botany, and natural history of that country..., } 2 \text { vols. } \\
\text { London: John Murray. Copy } 1 . \\
\text { Binding: 20th century leather and cloth boards. }\end{array}$ & $\begin{array}{l}\text { UoAL label, fly-leaf: replacement for Kidd bequest label due to Library rebind. } \\
\text { Accession: } 8301-8302 \text {. } \\
\text { Pencil markings, verso title page: } 2201 \text { [?] Pencil: dlf [?] Alf? }\end{array}$ \\
\hline 203 & $\begin{array}{l}\text { Dieffenbach, E. (1843). Travels in New Zealand, with contributions to the } \\
\text { geography, geology, botany, and natural history of that country..., vol. } 2 \\
\text { only. London: John Murray. Copy } 3 . \\
\text { Binding: 20th century leather and cloth boards. }\end{array}$ & UoAL label, front pastedown: Allan and Jess North. \\
\hline 204 & $\begin{array}{l}\text { (1845). Domestic scenes in New Zealand. London: Published under the } \\
\text { direction of the Committee of General Literature and Education... }\end{array}$ & $\begin{array}{l}\text { Ink inscription, FFEP: Grace Eliza Turner | With Aunt Caroline's And [... ? ] Love | } \\
\text { Decr. 25th } 1850\end{array}$ \\
\hline
\end{tabular}




\begin{tabular}{|c|c|c|}
\hline Record & Title details & Provenance evidence (stage one sample) \\
\hline & Binding: contemporary embossed cloth. & \\
\hline 206 & $\begin{array}{l}\text { Earle, A. (1832). A narrative of a nine months' residence in New Zealand in } \\
\text { 1827: together with a journal of a residence in Tristan D'Acunha, an island } \\
\text { situated between South America and the Cape of Good Hope. London: } \\
\text { Longman, Rees, Orme, Brown, Green \& Longman. Copy } 3 . \\
\text { Binding: 20th century cloth. }\end{array}$ & UoAL label, front pastedown: Allan and Jess North. \\
\hline 207 & $\begin{array}{l}\text { Heaphy, C. (1842). Narrative of a residence in various parts of New Zealand: } \\
\text { together with a description of the present state of the Company's } \\
\text { settlements... London: Smith, Elder. Copy } 3 . \\
\text { Binding: contemporary cloth. }\end{array}$ & $\begin{array}{l}\text { AUCL presentation label, fly-leaf: George Fowlds. } \\
\text { Ink stamp, verso title and other pages: The Property of the Government of New } \\
\text { South Wales. } \\
\text { Blind stamp, title page: Sold by the authority of the trustees of the public library } \\
\text { of New South Wales. [Overwritten in ink: Henry C L Anderson. Principal Librarian. }\end{array}$ \\
\hline 208 & $\begin{array}{l}\text { Heaphy, C. (1842). Narrative of a residence in various parts of New Zealand: } \\
\text { together with a description of the present state of the Company's } \\
\text { settlements... London: Smith, Elder. Copy } 1 . \\
\text { Binding: half calf and marbled boards, gilt. }\end{array}$ & $\begin{array}{l}\text { AUCL bequest label, front pastedown: Alfred Kidd. } \\
\text { Accession: } 8307 \text {. } \\
\text { Pencil marking, contents page: } r \text { [?] 14. } 30 \text { - }\end{array}$ \\
\hline 209 & $\begin{array}{l}\text { Hursthouse, C. (1849). An account of the settlement of New Plymouth, in } \\
\text { New Zealand, from personal observation, during a residence there of five } \\
\text { years... London: Smith, Elder. Copy } 1 . \\
\text { Binding: contemporary cloth, gilt. }\end{array}$ & $\begin{array}{l}\text { AUCL bequest label, front pastedown: Alfred Kidd. } \\
\text { Accession: } 8310 . \\
\text { Pencil marking, verso FFEP: B/ [?] /- } \\
\text { Binder's label, rear pastedown: Bound by | Westleys \& Co. | Friar Street. | London }\end{array}$ \\
\hline 210 & $\begin{array}{l}\text { Hursthouse, C. (1849). An account of the settlement of New Plymouth, in } \\
\text { New Zealand, from personal observation, during a residence there of five } \\
\text { years... London: Smith, Elder. Copy } 2 . \\
\text { Binding: contemporary cloth, gilt. }\end{array}$ & $\begin{array}{l}\text { AUCL presentation label, front pastedown: George Fowlds. } \\
\text { Binder's label, rear pastedown: Bound by | Westleys \& Co. | Friar Street. | London } \\
\text { Bookseller's stamp, front pastedown: T. Wright, | Bookseller, | Ponsonby [unclear } \\
\text { Rd?] } \\
\text { Ink inscription, title page: E J Lyr[...?] }\end{array}$ \\
\hline 212 & New Zealand Company. West of England Board. (1842). Latest information & Bookseller's label, front pastedown: Newbold's Bookshop Ltd. | 394 George Street \\
\hline
\end{tabular}




\begin{tabular}{|c|c|c|}
\hline Record & Title details & Provenance evidence (stage one sample) \\
\hline & $\begin{array}{l}\text { from the settlement of New Plymouth, on the coast of Taranake, New } \\
\text { Zealand...London: Smith, Elder and Co. Copy } 1 . \\
\text { Binding: 20th century cloth. }\end{array}$ & $\begin{array}{l}\text { I Dunedin, C.A. N.Z. } \\
\text { Pencil markings, illegible, to title page. }\end{array}$ \\
\hline 213 & $\begin{array}{l}\text { New Zealand Company. West of England Board. (1842). Latest information } \\
\text { from the settlement of New Plymouth, on the coast of Taranake, New } \\
\text { Zealand... London: Smith, Elder and Co. Copy } 2 . \\
\text { Binding: half leather and marbled boards. }\end{array}$ & $\begin{array}{l}\text { AUCL bequest label, front pastedown: Alfred Kidd. } \\
\text { Accession: } 8313 \text {. }\end{array}$ \\
\hline 214 & $\begin{array}{l}\text { Marjoribanks, A. (1846). Travels in New Zealand: with a map of the } \\
\text { country... London: Smith, Elder \& Co. Copy } 1 . \\
\text { Binding: contemporary cloth boards. }\end{array}$ & AUCL presentation label, front pastedown: George Fowlds. \\
\hline 215 & $\begin{array}{l}\text { Marjoribanks, A. (1846). Travels in New Zealand: with a map of the } \\
\text { country... London: Smith, Elder \& Co. Copy } 2 . \\
\text { Binding: contemporary cloth boards. }\end{array}$ & AUCL presentation label, front pastedown: George Fowlds. \\
\hline 216 & $\begin{array}{l}\text { Marshall, W.B. (1836). A personal narrative of two visits to New Zealand, in } \\
\text { His Majesty's ship Alligator, A.D. 1834. London: J. Nisbet. Copy } 2 . \\
\text { Binding: contemporary cloth. }\end{array}$ & $\begin{array}{l}\text { Stamp, fly-leaf: Tottenham \& Edmonton Mechanics Literary \& Scientific Institution } \\
\text { | Established [illegible]. } \\
\text { Pencil markings, front pastedown: \#261 abebooks. | Bought Bethunes auction } \\
22.10 .98 \text { | No. } 161 \$ 450 .\end{array}$ \\
\hline $217-218$ & $\begin{array}{l}\text { Nicholas, J.L. (1817). Narrative of a voyage to New Zealand, performed in } \\
\text { the years } 1814 \text { and } 1815 \text {, in company with the Rev. Samuel Marsden, } \\
\text { Principal Chaplain of New South Wales, } 2 \text { vols. London: Printed for James } \\
\text { Black and Son. Copy } 1 . \\
\text { Binding: 20th century cloth. }\end{array}$ & $\begin{array}{l}\text { Alfred Kidd accession: 8318-19. } \\
\text { Partial stamp, preface, vol. 1-2: Geo. D McVay }\end{array}$ \\
\hline $219-220$ & $\begin{array}{l}\text { Nicholas, J.L. (1817). Narrative of a voyage to New Zealand, performed in } \\
\text { the years } 1814 \text { and 1815, in company with the Rev. Samuel Marsden, } \\
\text { Principal Chaplain of New South Wales, } 2 \text { vols. London: Printed for James } \\
\text { Black and Son. Copy } 2 \text {. } \\
\text { Binding: 20th century cloth. }\end{array}$ & $\begin{array}{l}\text { AUCL presentation label, front pastedown: George Fowlds. } \\
\text { Letter to Sir George Fowlds tipped in before first fly-leaf: dated February } 1917 \\
\text { from the Beresford St Congregational Church gifting the two volumes "as a small } \\
\text { token of their esteem and appreciation of the many splendid services you have } \\
\text { rendered the Church". }\end{array}$ \\
\hline 221 & $\begin{array}{l}\text { Nicholas, J.L. (1819). Reise nach und in Neuseeland in den jahren } 1814 \text { und } \\
1815 \text { mit den, von Neuholland dahin reisenden, Missio-narien gemach... } \\
\text { Weimar [Germany]: im Verlage des Landes-Industrie-Comptoirs. } \\
\text { Binding: contemporary half calf and paper boards. Gilt armorial stamp to } \\
\text { front board. }\end{array}$ & $\begin{array}{l}\text { Gilt armorial stamp to front board. } \\
\text { Shelfmark label, in Russian, front pastedown. [Loosely translates to: Drawer: [MSS: } \\
\text { 51] | [...?] [MSS: IV] | No. } 21 \text {. }\end{array}$ \\
\hline
\end{tabular}




\begin{tabular}{|c|c|c|}
\hline Record & Title details & Provenance evidence (stage one sample) \\
\hline & & $\begin{array}{l}\text { Stamp, in Russian, title page, with MSS: 0-5167 . [For: Voenno-Inzhenernoi } \\
\text { Akademiia R.K.K.A . An engineering academy]. } \\
\text { Stamp, title page: } 1057 \text { [?]. }\end{array}$ \\
\hline 222 & $\begin{array}{l}\text { Petre, H.W. (1841). An account of the settlements of the New Zealand } \\
\text { Company: from personal observation during a residence there... London: } \\
\text { Smith, Elder and Co. Copy } 1 . \\
\text { Binding: contemporary cloth. }\end{array}$ & $\begin{array}{l}\text { AUCL presentation label: George Fowlds. } \\
\text { Ink inscription, FFEP: L A Necker [?] } \\
\text { Blind stamp, FFEP: Simpson \& Williams | Booksellers |Christchurch | N.Z. } \\
\text { Pencil index to some contents at rear. }\end{array}$ \\
\hline 223 & $\begin{array}{l}\text { Petre, H.W. (1841). An account of the settlements of the New Zealand } \\
\text { Company: from personal observation during a residence there... London: } \\
\text { Smith, Elder and Co. Copy } 2 . \\
\text { Binding: half calf and marbled boards, gilt. }\end{array}$ & $\begin{array}{l}\text { AUCL bequest label, front pastedown: Alfred Kidd. } \\
\text { Accession: } 8166 .\end{array}$ \\
\hline 224 & $\begin{array}{l}\text { Petre, H.W. (1842). An account of the settlements of the New Zealand } \\
\text { Company: from personal observation during a residence there... London: } \\
\text { Smith, Elder and Co. } \\
\text { Binding: 20th century cloth. }\end{array}$ & Replacement presentation label, fly-leaf: Mr George Fowlds [Library rebind]. \\
\hline 225 & $\begin{array}{l}\text { Polack, J.S. (1840). Manners and customs of the New Zealanders: with notes } \\
\text { corroborative of their habits, usages, etc., and remarks to intending } \\
\text { emigrants..., } 2 \text { vols. bound in } 1 . \text { London: J. Madden. Copy } 1 . \\
\text { Binding: Half leather and marbled boards. }\end{array}$ & $\begin{array}{l}\text { AUCL bequest label, front pastedown: Alfred Kidd. } \\
\text { Accession: } 8323 \text {. }\end{array}$ \\
\hline $226-227$ & $\begin{array}{l}\text { Polack, J.S. (1840). Manners and customs of the New Zealanders: with notes } \\
\text { corroborative of their habits, usages, etc., and remarks to intending } \\
\text { emigrants..., } 2 \text { vols. London: J. Madden. Copy } 2 . \\
\text { Binding: vol.1: } 20 \text { th century cloth; vol. 2: contemporary leather and } \\
\text { marbled boards. }\end{array}$ & AUCL presentation label, vol. 2: George Fowlds. \\
\hline $230-231$ & $\begin{array}{l}\text { Polack, J.S. (1840). Manners and customs of the New Zealanders: with notes } \\
\text { corroborative of their habits, usages, etc., and remarks to intending } \\
\text { emigrants..., } 2 \text { vols. London: J. Madden. Copy } 4 . \\
\text { Binding: contemporary half calf and marbled boards, gilt. }\end{array}$ & $\begin{array}{l}\text { UoAL label, front pastedown, vol. 1-2: Allan and Jess North. } \\
\text { Ink inscription, front pastedown, vol. 1-2: Allan North, | Te Whaiti, | } 11.9 .52 \\
\text { Ink inscription, front and rear pastedown, title page, vol. 1-2: Geo. Innes [?] }\end{array}$ \\
\hline
\end{tabular}




\begin{tabular}{|c|c|c|}
\hline Record & Title details & Provenance evidence (stage one sample) \\
\hline & & Binder's stamp, verso FFEP, vols. 1-2: Bound by Worsfold. \\
\hline $232-233$ & $\begin{array}{l}\text { Polack, J.S. (1838). New Zealand: being a narrative of travels and } \\
\text { adventures during a residence in that country between the years } 1831 \text { and } \\
\text { 1837, } 2 \text { vols. London: Bentley. Copy } 1 . \\
\text { Binding: half calf and marbled boards. }\end{array}$ & $\begin{array}{l}\text { UoAL replacement gift label, fly-leaf, vol. 2: Alfred Kidd [Library rebind]. } \\
\text { Accession: 8324-8325. } \\
\text { Pencil annotations, rear pages. }\end{array}$ \\
\hline $234-235$ & $\begin{array}{l}\text { Polack, J.S. (1838). New Zealand: being a narrative of travels and } \\
\text { adventures during a residence in that country between the years } 1831 \text { and } \\
\text { 1837, } 2 \text { vols. London: Bentley. Copy } 2 . \\
\text { Binding: half calf and marbled boards, gilt. }\end{array}$ & AUCL presentation label, FFEP, vol. 1-2: George Fowlds. \\
\hline $237-238$ & $\begin{array}{l}\text { Polack, J.S. (1839). New Zealand: being a narrative of travels and } \\
\text { adventures during a residence in that country between the years } 1831 \text { and } \\
\text { 1837..., New ed. } 2 \text { vols. London: Bentley. } \\
\text { Binding: paper boards and cloth spine. }\end{array}$ & $\begin{array}{l}\text { UoAL label, verso FFEP, vol. 1-2: Allan and Jess North. } \\
\text { Ink inscription, FFEP, vol. 1-2: Allan North, | Te Whaiti, | } 11.9 .52 \\
\text { Ink inscription, ca. 19th century, FFEP vol. 1: J C. Mathews | Plymouth. } \\
\text { Pencil markings, FFEP, vol. 1: f8-8.0 } \\
\text { Label, front pastedown, vol. 1: E. Nettleton, | Bookseller and Stationer | to the } \\
\text { Queen | Plymouth }\end{array}$ \\
\hline 239 & $\begin{array}{l}\text { Power, W.T. (1849). Sketches in New Zealand, with pen and pencil: from a } \\
\text { journal kept in that country from July 1846, to June 1848. London: } \\
\text { Longman, Brown, Green, and Longmans. Copy } 1 . \\
\text { Binding: } 20^{\text {th }} \text { century quarter leather and cloth boards. }\end{array}$ & $\begin{array}{l}\text { UoAL replacement gift label, verso FFEP: Alfred Kidd [Library rebind]. } \\
\text { Accession: } 8326 \text {. } \\
\text { Tipped in to fly-leaf, a printed lending label for Newark Book Society with MSS } \\
\text { showing circulation between } 1849 \text { and } 1851 \text {. }\end{array}$ \\
\hline 240 & $\begin{array}{l}\text { Power, W.T. (1849). Sketches in New Zealand, with pen and pencil: from a } \\
\text { journal kept in that country from July 1846, to June 1848. London: } \\
\text { Longman, Brown, Green, and Longmans. Copy } 2 \text {. } \\
\text { Binding: } 20^{\text {th }} \text { century quarter leather and cloth boards. }\end{array}$ & UoAL replacement gift label, verso FFEP: George Fowlds [Library rebind]. \\
\hline 241 & $\begin{array}{l}\text { Power, W.T. (1849). Sketches in New Zealand, with pen and pencil: from a } \\
\text { journal kept in that country from July 1846, to June 1848. London: } \\
\text { Longman, Brown, Green, and Longmans. Copy } 3 \text {. } \\
\text { Binding: } 20^{\text {th }} \text { century quarter leather and cloth boards. }\end{array}$ & $\begin{array}{l}\text { UoAL replacement gift label, verso FFEP: George Fowlds [Library rebind]. } \\
\text { [Second Fowlds copy of this title] } \\
\text { Pencil marking, trimmed away, title page: } 10 /-\end{array}$ \\
\hline
\end{tabular}




\begin{tabular}{|c|c|c|}
\hline $\begin{array}{l}\text { Record } \\
\text { no. }\end{array}$ & Title details & Provenance evidence (stage one sample) \\
\hline 244 & $\begin{array}{l}\text { Savage, J. (1807). Some account of New Zealand: particularly the Bay of } \\
\text { Islands and surrounding country; with a description of the religion and } \\
\text { government, language, arts, manufactures, manners, and customs of the } \\
\text { natives, etc. etc. London: Printed for J. Murray. } \\
\text { Binding: } 20^{t} \mathrm{~h} \text { century leather. }\end{array}$ & $\begin{array}{l}\text { Alfred Kidd accession: 8331. [Library rebind]. } \\
\text { Occasional pencil markings, ca. 19th-20th century, to text block. }\end{array}$ \\
\hline 245 & $\begin{array}{l}\text { Symonds, W.C. (1838). Notes on Cloudy bay and harbour, and on some } \\
\text { other harbours in New Zealand. [S.I.: s.n., 1838]. } \\
\text { Binding: half cloth and paper boards. }\end{array}$ & $\begin{array}{l}\text { Bookseller's label, front pastedown: Newbold's Bookshop Ltd. | } 394 \text { George } \\
\text { Street, I Dunedin, C.1., N.Z. }\end{array}$ \\
\hline 247 & $\begin{array}{l}\text { Wade, W.R. (1842). A journey in the northern island of New Zealand: } \\
\text { interspersed with various information relative to the country and people. } \\
\text { Hobart Town [Tas.]: George Rolwegan. Copy } 2 . \\
\text { Binding: cloth boards, gilt. }\end{array}$ & $\begin{array}{l}\text { UoAL label, front pastedown: Allan and Jess North. } \\
\text { Ink inscription, ca. 19th century, title page: Samuel [Page?]. } \\
\text { [The list of subscribers includes an S. Page.] }\end{array}$ \\
\hline 248 & $\begin{array}{l}\text { Wakefield, E.J. (1848). The hand-book for New Zealand: consisting of the } \\
\text { most recent information compiled for the use of intending colonists / by a } \\
\text { late magistrate of the colony who resided there during four years. London: } \\
\text { Parker. Copy } 1 . \\
\text { Binding: contemporary embossed cloth. }\end{array}$ & $\begin{array}{l}\text { AUCL bequest label, front pastedown: Alfred Kidd. } \\
\text { Accession: } 8400 \text {. } \\
\text { Faint, partly erased pencil calculations, rear pastedown and endpaper. }\end{array}$ \\
\hline 249 & $\begin{array}{l}\text { Wakefield, E.J. (1848). The hand-book for New Zealand: consisting of the } \\
\text { most recent information compiled for the use of intending colonists / by a } \\
\text { late magistrate of the colony who resided there during four years. London: } \\
\text { Parker. Copy } 2 \text {. } \\
\text { Binding: contemporary embossed cloth. }\end{array}$ & $\begin{array}{l}\text { AUCL presentation label, rear pastedown: George Fowlds. } \\
\text { Ink inscription, front pastedown: Robert McNab | Invercargill, N.Z. | } 1897 . \\
\text { Tipped in: Printed sheet titled: Canterbury Ass. For Founding a settlement in NZ, } \\
\text { dated 1850, [re. those intending to emigrate]. }\end{array}$ \\
\hline 250 & $\begin{array}{l}\text { Wakefield, E.J. (1848). The hand-book for New Zealand: consisting of the } \\
\text { most recent information compiled for the use of intending colonists / by a } \\
\text { late magistrate of the colony who resided there during four years. London: } \\
\text { Parker. Copy } 3 . \\
\text { Binding: contemporary embossed cloth. }\end{array}$ & AUCL presentation label: George Fowlds. \\
\hline $250 A$ & $\begin{array}{l}\text { Ward, J. (1840). Information relative to New Zealand / compiled for the use } \\
\text { of colonists, } 2 \text { nd ed. London: John W. Parker. Copy } 1 . \\
\text { Binding: contemporary embossed cloth. }\end{array}$ & $\begin{array}{l}\text { AUCL presentation label, front pastedown: Presented to the | Auckland University } \\
\text { College | Library | by | MSS: E. Earle Vaile, Esq. | } 1939 \\
\text { Pencil marking, verso FFEP: W [?] C/- | 35/- }\end{array}$ \\
\hline
\end{tabular}




\begin{tabular}{|c|c|c|}
\hline $\begin{array}{l}\text { Record } \\
\text { no. }\end{array}$ & Title details & Provenance evidence (stage one sample) \\
\hline 252 & $\begin{array}{l}\text { Ward, J. (1842). New Zealand: Nelson, the latest settlement of the New } \\
\text { Zealand Company. London: Smith, Elder and Co. Copy } 2 . \\
\text { Binding: Half leather and marbled boards, gilt. }\end{array}$ & $\begin{array}{l}\text { Ink inscription, fly-leaf: E.H. McCormick. | With Compliments. | Nelson. | 11.8.37. } \\
\text { UoAL bequest label, verso FFEP: The University Library I [MSS:] bequest from the } \\
\text { library of E.H. McCormick. }\end{array}$ \\
\hline 254 & $\begin{array}{l}\text { Ward, J. (1840). Supplementary information relative to New-Zealand: } \\
\text { comprising despatches and journals of the Company's officers of the first } \\
\text { expedition, and the first report of the directors. London: John W. Parker. } \\
\text { Binding: half leather and marbled boards over publishers' paper boards. }\end{array}$ & $\begin{array}{l}\text { Ink inscription, front paper board: L Colonel Angelo. } \\
\text { Ink inscription, verso FFEP: H. J [?]. Todd | } 20 \text { June } 1872 \text { | A present from Michael } \\
\text { Angelo } \\
\text { Bookseller's label, front pastedown: Newbold's Bookshop Ltd. | } 394 \text { George } \\
\text { Street, | Dunedin, C.1., N.Z. }\end{array}$ \\
\hline 255 & $\begin{array}{l}\text { Yate, W. (1835). An account of New Zealand and of the formation and } \\
\text { progress of the Church Missionary Society's mission in the northern island. } \\
\text { London: Seeley and Burnside. Copy } 1 . \\
\text { Binding: 20th century cloth. }\end{array}$ & Pencil inscription, preface: C.E.H | 6th Sep 1871 \\
\hline 256 & $\begin{array}{l}\text { Yate, W. (1835). An account of New Zealand and of the formation and } \\
\text { progress of the Church Missionary Society's mission in the northern island. } \\
\text { London: Seeley and Burnside. Copy } 2 . \\
\text { Binding: contemporary cloth. }\end{array}$ & $\begin{array}{l}\text { AUCL bequest label, FFEP: Alfred Kidd. } \\
\text { Accession: } 8342 \text {. } \\
\text { Occasional pencil annotations, ca. 20th century, highlighting text. }\end{array}$ \\
\hline 257 & $\begin{array}{l}\text { Yate, W. (1835). An account of New Zealand and of the formation and } \\
\text { progress of the Church Missionary Society's mission in the northern island, } \\
\text { 2nd ed. London: Seeley and Burnside. Copy } 4 . \\
\text { Binding: contemporary cloth. }\end{array}$ & $\begin{array}{l}\text { Ink inscription, FFEP: Presented to | Jane L[?]anning | by her affectionate Father | } \\
\text { November } 1835 . \\
\text { Pencil markings, verso FFEP: £] 1-0.0. [?] Pencil: Coll / 13.8.31 | C.C. [in a circle] }\end{array}$ \\
\hline 258 & $\begin{array}{l}\text { Yate, W. (1835). An account of New Zealand and of the formation and } \\
\text { progress of the Church Missionary Society's mission in the northern island, } \\
\text { 2nd ed. London: Seeley and Burnside. Copy } 5 . \\
\text { Binding: cloth boards. }\end{array}$ & $\begin{array}{l}\text { Ink inscription, front pastedown: Allan North, | Te Whaiti, | } 16 \text { June } 1952 . \\
\text { UoAL label, front pastedown: Allan and Jess North. }\end{array}$ \\
\hline 261 & $\begin{array}{l}\text { 1843. London. Letters from settlers \& labouring emigrants, in the New } \\
\text { Zealand Company's settlements of Wellington, Nelson \& New Plymouth: } \\
\text { From February, 1842, to January, 1843. Letters from New Plymouth, } 1843 . \\
\text { London: Smith Elder. Copy } 2 . \\
\text { Binding: 20th century leather. }\end{array}$ & $\begin{array}{l}\text { Bookseller's label, title page: Newbold's Bookshop Ltd. | } 394 \text { George Street, | } \\
\text { Dunedin, C.1., N.Z. } \\
\text { Occasional pencil markings, ca. 20th century, to text block. }\end{array}$ \\
\hline
\end{tabular}




\begin{tabular}{|c|c|c|}
\hline $\begin{array}{l}\text { Record } \\
\text { no. }\end{array}$ & Title details & Provenance evidence (stage one sample) \\
\hline 263 & $\begin{array}{l}\text { Dalrymple, A. (1774). Voyages dans la mer du Sud: par les Espagnols et les } \\
\text { Hollandois. / ouvrage traduit de langlois de M. Dalrymple, par M. de } \\
\text { Freville. Paris: Saillant \& Nyon. } \\
\text { Binding: full mottled leather, gilt. }\end{array}$ & $\begin{array}{l}\text { Anonymous armorial bookplate, front pastedown: motto: He plaa diu t'ayudy. } \\
\text { [Possibly for a member of the French Laussat family]. } \\
\text { Ink marking, n.d., verso fly-leaf: in } 8 .^{0 .} \text {... 5th [?] | hist. sect. [?] Geograp. | v. Voyag. } \\
\text { Et [illegible] | S [or } 5 \text { ?].3. } \\
\text { Pencil marking, short title page: Ex Laussat }\end{array}$ \\
\hline 265 & $\begin{array}{l}\text { Wilson, J. (1799). A missionary voyage to the southern Pacific ocean: } \\
\text { performed in the years 1796-1797, 1798, in the ship Duff, commanded by } \\
\text { Captain James Wilson... London: Chapman. Copy } 1 . \\
\text { Binding: contemporary half leather and marbled boards. }\end{array}$ & $\begin{array}{l}\text { Pencil inscription, title page: Peter F. Sparke | Donum of Mr | Edw } \\
\text { [Harling/Hurling?] } 1800 . \\
\text { Bibliographic description, ca. 20th century, verso FFEP. }\end{array}$ \\
\hline 266 & $\begin{array}{l}\text { Wilson, J. (1799). A missionary voyage to the southern Pacific ocean: } \\
\text { performed in the years 1796-1797, 1798, in the ship Duff, commanded by } \\
\text { Captain James Wilson... London: Chapman. Copy } 2 . \\
\text { Binding: 20th century cloth, gilt. }\end{array}$ & $\begin{array}{l}\text { Alfred Kidd accession: } 8402 \text {. } \\
\text { Ink marking, fly-leaf: } £ 3-10\end{array}$ \\
\hline $270-271$ & $\begin{array}{l}\text { Martin, J. (1817). An account of the natives of the Tonga Islands, in the } \\
\text { South Pacific Ocean, with an original grammar and vocabulary of their } \\
\text { language compiled and arranged from the extensive communications of Mr. } \\
\text { William Mariner, several years resident in those islands.., } 2 \text { vols. London: J. } \\
\text { Murray. Copy } 2 . \\
\text { Binding: contemporary full tree calf, gilt. }\end{array}$ & $\begin{array}{l}\text { Pencil marking, front pastedown, vol. 1-2: } 2 \text { / } 10 \text { / - } \\
\text { Ink inscription, dedication page, vol. 1, title page, vol. 2: C E Maguire | from N L [?] } \\
\text { Plunket | T R Salisbury | Dec. } 06\end{array}$ \\
\hline $272-273$ & $\begin{array}{l}\text { Martin, J. (1818). An account of the natives of the Tonga Islands, in the } \\
\text { South Pacific Ocean, with an original grammar and vocabulary of their } \\
\text { language compiled and arranged from the extensive communications of Mr. } \\
\text { William Mariner, several years resident in those islands... } 2 \mathrm{~d} \text { ed., with } \\
\text { additions. London: J. Murray. } 2 \text { vols. } \\
\text { Binding: contemporary paper boards, cloth spine. }\end{array}$ & Alfred Kidd accession: 8248- 8249. \\
\hline 275 & $\begin{array}{l}\text { Martin, J. (1827). An account of the natives of the Tonga Islands, in the } \\
\text { South Pacific Ocean, with an original grammar and vocabulary of their } \\
\text { language, compiled and arranged from the extensive communications of } \mathrm{Mr} \\
\text { William Mariner, several years resident in those islands, 3rd ed. Copy 1, Vol. } \\
2 . \\
\text { Binding: contemporary half leather and marbled boards. }\end{array}$ & $\begin{array}{l}\text { UoAL gift label, on flag: The University Library | University of Auckland | Given by } \\
\text { [typed: In memory of L.M. Lennard | of Pukekohe, (1903-1988) | } 1989 .\end{array}$ \\
\hline
\end{tabular}




\begin{tabular}{|c|c|c|}
\hline $\begin{array}{l}\text { Record } \\
\text { no. }\end{array}$ & Title details & Provenance evidence (stage one sample) \\
\hline 277 & $\begin{array}{l}\text { Walther, F.L. (1787). Natuur en aardrijkskundige beschrijving der Vriendlijke } \\
\text { Eilanden in de groote Zuidzee, volgens de Nieuwste ontdekkingen ... } \\
\text { Amsterdam: Martinus de Bruijn. } \\
\text { Binding: half cloth and marbled boards. }\end{array}$ & $\begin{array}{l}\text { Armorial bookplate, front pastedown: Ex Libris | A. de Kluijs } \\
\text { Ink stamp, FFEP: A.P.M. de Kluys- | van der meijde, Tilburg. } \\
\text { [A.P.M. de Kluys (1905-1973), of Tilburg, Netherlands]. } \\
\text { Ink stamp, FFEP: Glen \& C.E. Crothers }\end{array}$ \\
\hline 280 & $\begin{array}{l}\text { Keate, G. \& Wilson, H. (1788). An account of the Pelew Islands: situated in } \\
\text { the western part of the Pacific Ocean: composed from the journals and } \\
\text { communications of Captain Henry Wilson, and some of his officers... } \\
\text { London: Printed for Captain Wilson. Copy } 1 . \\
\text { Binding: contemporary full leather, gilt. }\end{array}$ & $\begin{array}{l}\text { AUCL bequest label, front pastedown: Alfred Kidd. } \\
\text { Accession: } 8418 \text {. }\end{array}$ \\
\hline 281 & $\begin{array}{l}\text { Keate, G. \& Wilson, H. (1788). An account of the Pelew Islands: situated in } \\
\text { the western part of the Pacific Ocean: composed from the journals and } \\
\text { communications of Captain Henry Wilson, and some of his officers... } \\
\text { London: Printed for Captain Wilson. Copy } 2 . \\
\text { Binding: twentieth century half leather and cloth boards. }\end{array}$ & AUCL presentation label, fly-leaf: George Fowlds. \\
\hline 282 & $\begin{array}{l}\text { Keate, G. \& Wilson, H. (1788). An account of the Pelew Islands: situated in } \\
\text { the western part of the Pacific Ocean: composed from the journals and } \\
\text { communications of Captain Henry Wilson, and some of his officers, who, in } \\
\text { August, 1783, were there shipwrecked, in the Antelope, a packet belonging } \\
\text { to the Honourable East India Company. London: Printed for Captain Wilson. } \\
\text { Copy } 3 . \\
\text { Binding: twentieth century half leather and cloth boards. }\end{array}$ & Ink inscription, ca. 19th century, fly-leaf: A Galloway \\
\hline 284 & $\begin{array}{l}\text { Wilson, } \mathrm{H} . \text { (1789). The interesting and affecting history of Prince Lee Boo, a } \\
\text { native of the Pelew Islands, brought to England by Capt. Wilson: To which is } \\
\text { prefixed, A short account of those islands, with a sketch of the manners and } \\
\text { customs of the inhabitants. London: Printed for E. Newbery. } \\
\text { Binding: contemporary quarter leather and marbled boards. }\end{array}$ & $\begin{array}{l}\text { Ink inscription, verso FFEP: Sydney George Hetherington I with his grandfather's | } \\
\text { best love } 1879 . \\
\text { [May indicate Sydney Hetherington (1870-?), grandson of George Hoste]. } \\
\text { Ink inscription, verso FFEP: George Charles Hoste } \\
\text { [May indicate Rev. George Hoste (1813-1892) of Eastbourne, Sussex, England] }\end{array}$ \\
\hline
\end{tabular}




\begin{tabular}{|c|c|c|}
\hline $\begin{array}{l}\text { Record } \\
\text { no. }\end{array}$ & Title details & Provenance evidence (stage one sample) \\
\hline 286 & $\begin{array}{l}\text { Ellis, W. (1826). Narrative of a tour through Hawaii, or Owhyhee: with } \\
\text { remarks on the history, traditions, manners, customs, and language of the } \\
\text { inhabitants of the Sandwich Islands. London: For the author, by H. Fisher, } \\
\text { Son, and P. Jackson. Copy } 1 . \\
\text { Binding: ca. 20th century cloth. }\end{array}$ & $\begin{array}{l}\text { Pictorial bookplate, front pastedown: A L Chappell. } \\
\text { Ink stamp, FFEP: Samuel L Chapman. }\end{array}$ \\
\hline 287 & $\begin{array}{l}\text { Simpson, G., Sir. (1847[?]). Sandwich Islands. Philadelphia: Lea and } \\
\text { Blanchard[?] } \\
\text { Binding: ca. contemporary cloth. }\end{array}$ & Pictorial bookplate, front pastedown: A L Chappell. \\
\hline 289 & $\begin{array}{l}\text { Tomlinson, C. (1848). Summer in the Antarctic regions: a narrative of } \\
\text { voyages of discovery towards the South Pole. London: Printed for the } \\
\text { Society for Promoting Christian Knowledge. } \\
\text { Binding: contemporary cloth. }\end{array}$ & $\begin{array}{l}\text { Label: Camden Temperance | Library. | President : - | Ven. Archdeacon } \\
\text { Richardson. | No: ... [MSS: } 252 \text { | This book to be returned in a Week. } \\
\text { Binder's ticket: S. Curtis. | Binder }\end{array}$ \\
\hline $290-291$ & $\begin{array}{l}\text { Ross, J.C., Sir. (1847). A voyage of discovery and research in the southern } \\
\text { and Antarctic regions, during the years } 1839-43 \ldots, 2 \text { vols. London: John } \\
\text { Murray. } \\
\text { Binding: } 19^{\text {th }} \text { century cloth. }\end{array}$ & $\begin{array}{l}\text { AUCL bequest label, front pastedown, vol. 1-2: Alfred Kidd. } \\
\text { Accession: 8328-8329. } \\
\text { Binder's label, front pastedown, vol. 1-2: Leighton. | Book-binder | \& Account } \\
\text { book | manufacturer. | High St Auckland | Bowring \& Usher. } \\
\text { Fern pressed between rear pastedown and RFEP. }\end{array}$ \\
\hline
\end{tabular}


Appendix 3: Stage one sampled works from Alfred Kidd's bequest

\begin{tabular}{|c|c|c|}
\hline $\begin{array}{l}\text { Record } \\
\text { no. }\end{array}$ & Title details & Provenance evidence (Stage one sampled works from Alfred Kidd's bequest) \\
\hline 014-16 & $\begin{array}{l}\text { Hawkesworth, J. (1773). An account of the voyages undertaken by the order } \\
\text { of His Present Majesty for making discoveries in the southern hemisphere, } \\
\text { and successively performed by Commodore Byron, Captain Carteret, } \\
\text { Captain Wallis, and Captain Cook..., } 3 \text { vols. London: Printed for W. Strahan } \\
\text { and T. Cadell. } \\
\text { Binding: ca. 18th-19th century full leather, gilt. }\end{array}$ & $\begin{array}{l}\text { AUCL bequest label, front pastedown, vol. 1-3: Bequeathed | to the | University } \\
\text { College Library | Auckland | by | Alfred Kidd, Esq., | Late Member of the House of } \\
\text { Representatives | and Mayor of Auckland. | 1918. } \\
\text { [After this shortened to AUCL bequest label: Alfred Kidd]. } \\
\text { Accession: } 8414-8416 .\end{array}$ \\
\hline 031-033 & $\begin{array}{l}\text { Cook, J., \& King, J. (1785). A voyage to the Pacific ocean. Undertaken, by the } \\
\text { command of His Majesty, for making discoveries in the northern } \\
\text { hemisphere. Performed under the direction of Captains Cook, Clerke, and } \\
\text { Gore, in His Majesty's ships the Resolution and Discovery; in the years 1776, } \\
1777,1778,1779, \text { and } 1780 \text {..., } 3 \text { vols. London: G. Nicol and T. Cadell. } \\
\text { Binding: ca. 19th century full calf, gilt. }\end{array}$ & $\begin{array}{l}\text { AUCL bequest label, front pastedown, vol. 1-3: Alfred Kidd. } \\
\text { Accession: 8409-8411. }\end{array}$ \\
\hline 037-038 & $\begin{array}{l}\text { Cook, J. (1777). A voyage towards the South Pole, and round the world: } \\
\text { performed in His Majesty's ships the 'Resolution 'and 'Adventure', in the } \\
\text { year } 1772,1773,1774 \text {, and } 1775 \ldots, 2 \text { vols. London: Printed for W. Strahan } \\
\text { and T. Cadell. } \\
\text { Binding: ca. 19th century full calf, gilt. }\end{array}$ & $\begin{array}{l}\text { AUCL bequest label, front pastedown, vol. 1-2: Alfred Kidd. } \\
\text { Accession: 8426-8427. }\end{array}$ \\
\hline 051-052 & $\begin{array}{l}\text { Forster, G. (1777). A voyage round the world in His Britannic Majesty's } \\
\text { sloop, Resolution, commanded by Capt. James Cook, during the years 1772, } \\
3,4 \text { and 5..., } 2 \text { vols. London: Printed for B. White, Fleet-Street J. Robson, } \\
\text { Bond Street; P. Elmsly, Strand... } \\
\text { Binding: ca. 19th century full calf, gilt. }\end{array}$ & $\begin{array}{l}\text { AUCL bequest label, front pastedown, vol. 1-2: Alfred Kidd. } \\
\text { Accession: } 8412-8413 .\end{array}$ \\
\hline 060-061 & $\begin{array}{l}\text { Dillon, P. (1829). Narrative and successful result of a voyage in the south } \\
\text { seas: performed by order of the Government of British India, to ascertain } \\
\text { the actual fate of La Pérouse's expedition... London: Hurst, Chance. } \\
\text { Binding: Vol. 1: contemporary half-leather and marbled boards. Vol. 2: 20th } \\
\text { century cloth. }\end{array}$ & $\begin{array}{l}\text { AUCL bequest label, front pastedown, vol. 1: Alfred Kidd. } \\
\text { Accession: } 8228-8229\end{array}$ \\
\hline 070-071 & $\begin{array}{l}\text { Stewart, C.S. (1832). A visit to the South Seas, in the United States' ship } \\
\text { Vincennes, during the years } 1829 \text { and } 1830: \text { including scenes in Brazil, Peru, } \\
\text { Manilla, the Cape of Good Hope, and St. Helena, } 2 \text { vols. London: Colburn } \\
\text { and Bentley. }\end{array}$ & $\begin{array}{l}\text { AUCL bequest label, front pastedown, vol. 1-2: Alfred Kidd. } \\
\text { Accession: 8216-8217. }\end{array}$ \\
\hline
\end{tabular}




\begin{tabular}{|c|c|c|}
\hline Record & Title details & Provenance evidence (Stage one sampled works from Alfred Kidd's bequest) \\
\hline & Binding: contemporary paper boards, rebacked. & \\
\hline 084 & $\begin{array}{l}\text { Wilkes, C. (1845). Narrative of the United States Exploring Expedition, } \\
\text { during the years 1838, 1840, 1841, 1842. Condensed and abridged [ed.]. } \\
\text { London: Whittaker and Co. } \\
\text { Binding: 20th century cloth boards. }\end{array}$ & $\begin{array}{l}\text { AUCL bequest: Alfred Kidd. } \\
\text { Accession: } 8221 .\end{array}$ \\
\hline $099-101$ & $\begin{array}{l}\text { Kotzebue, O. von. (1821). A voyage of discovery, into the South Sea and } \\
\text { Beering's Straits, for the purpose of exploring a north-east passage: } \\
\text { undertaken in the years } 1815-1818 \text {, at the expense of His Highness ..., } 3 \\
\text { vols. London: Longman, Hurst, Rees, Orme, and Brown. Copy } 1 . \\
\text { Binding: contemporary pasteboards, paper label, uncut edges. }\end{array}$ & $\begin{array}{l}\text { AUCL bequest label, front pastedown, vol. 1-3: Alfred Kidd. } \\
\text { Accession: 8218-8220. } \\
\text { Pencil markings, front pastedown: 72/. } \\
\text { Pencil markings, FFEP: f7.10 } \\
\text { Binder's label, front pastedown, vol. 1-3: G. Peck, | Bookbinder }\end{array}$ \\
\hline 148 & $\begin{array}{l}\text { Goodridge, C.M. (1841). Narrative of a voyage to the South Seas, and the } \\
\text { shipwreck of the Princess of Wales cutter: with an account of two years } \\
\text { residence on an uninhabited island. London: W.C. Featherstone. } \\
\text { Binding: 20th century cloth. }\end{array}$ & $\begin{array}{l}\text { UoAL replacement label, fly-leaf [volume rebound]: The gift of [MSS: Mr. Alfred } \\
\text { Kidd] to the University of Auckland Library. } \\
\text { Accession: } 8245 \text {. }\end{array}$ \\
\hline 161 & $\begin{array}{l}\text { Earl, G.W. (1837). The eastern seas, or, Voyages and adventures in the } \\
\text { Indian Archipelago in 1832-33-34: comprising a tour of the island of Java, } \\
\text { visits to Borneo, the Malay Peninsula, Siam, etc... London: Wm. H. Allen. } \\
\text { Binding: ca. } 20^{\text {th }} \text { century cloth. }\end{array}$ & $\begin{array}{l}\text { AUCL bequest label, front pastedown: Alfred Kidd. } \\
\text { Accession: } 8224 \text {. }\end{array}$ \\
\hline 167 & $\begin{array}{l}\text { Forrest, T. (1780). A voyage to New Guinea and the Moluccas, from } \\
\text { Balambangan: including an account of Magindano, Sooloo, and other } \\
\text { islands ..., 2nd ed. London: Printed by G. Scott. } \\
\text { Binding: ca. 19th century half calf and marbled boards. }\end{array}$ & $\begin{array}{l}\text { AUCL bequest label, FFEP: Alfred Kidd. } \\
\text { Accession: } 8422 \text {. } \\
\text { Inscription, ca. 18th-19th century, recto frontispiece: George Bidwood }\end{array}$ \\
\hline $170-171$ & $\begin{array}{l}\text { Angas, G.F. (1847). Savage life and scenes in Australia and New Zealand: } \\
\text { being an artist's impressions of countries and people at the antipodes..., } \\
\text { 2nd. Ed. } 2 \text { vols. London: Smith, Elder and Co. Copy } 2 . \\
\text { Binding: contemporary cloth boards, rebacked. }\end{array}$ & $\begin{array}{l}\text { AUCL bequest label, front pastedown, vol. 1-2: Alfred Kidd. } \\
\text { Accession. 8261-8262. }\end{array}$ \\
\hline 173 & $\begin{array}{l}\text { Backhouse, J. (1843). A narrative of a visit to the Australian colonies. } \\
\text { London: Hamilton, Adams, and Co. } \\
\text { Binding: 20th century rebind. }\end{array}$ & $\begin{array}{l}\text { AUCL bequest label, front pastedown: Alfred Kidd. } \\
\text { Accession: } 8286 .\end{array}$ \\
\hline
\end{tabular}




\begin{tabular}{|c|c|c|}
\hline $\begin{array}{l}\text { Record } \\
\text { no. }\end{array}$ & Title details & Provenance evidence (Stage one sampled works from Alfred Kidd's bequest) \\
\hline 174 & $\begin{array}{l}\text { Jameson, R.G. (1842). New Zealand, South Australia, and New South Wales: } \\
\text { a record of recent travels in these colonies, with especial reference to } \\
\text { emigration and the advantageous employment of labour and capital. } \\
\text { London: Smith, Elder. Copy } 1 . \\
\text { Binding: 20th century quarter leather and cloth boards. }\end{array}$ & $\begin{array}{l}\text { UoAL gift label, recto frontispiece: The gift of Mr. Alfred Kidd to the University of } \\
\text { Auckland Library [replacement label, Library rebind]. } \\
\text { Accession: } 8269 . \\
\text { Pencil inscription, title page: A Kidd. } \\
\text { Ink inscription, ca. 19th century, title page: Walter Booth }\end{array}$ \\
\hline 176 & $\begin{array}{l}\text { Oxley, J. (1820). Journals of two expeditions into the interior of New South } \\
\text { Wales: undertaken by order of the British Government in the years 1817-18. } \\
\text { London: John Murray. } \\
\text { Binding: ca. contemporary leather and marbled boards. }\end{array}$ & $\begin{array}{l}\text { AUCL bequest label, front pastedown: Alfred Kidd. } \\
\text { Accession: } 8421 . \\
\text { Pencil marking, front pastedown: [illegible]. Pencil: R/R [illegible], Pencil: } 33 \text {. } \\
\text { Pencil: Australia | Oxley. } \\
\text { Pencil marking, FFEP: f5.5 }\end{array}$ \\
\hline 177 & $\begin{array}{l}\text { Angas, G.F. (1847). South Australia illustrated. London: Thomas M'lean. } \\
\text { Binding: cloth case, leather boards. }\end{array}$ & $\begin{array}{l}\text { AUCL bequest label, front pastedown: Alfred Kidd. } \\
\text { Accession: } 8424 \text {. }\end{array}$ \\
\hline 178 & $\begin{array}{l}\text { Angas, G.F. (1847). The New Zealanders illustrated. London: Thomas } \\
\text { M'lean. Copy } 1 . \\
\text { Binding: cloth case, leather boards. }\end{array}$ & $\begin{array}{l}\text { AUCL bequest label, front pastedown: Alfred Kidd. } \\
\text { Accession: } 8425 . \\
\text { Bookseller's label, rear pastedown: Matthews | and | Brooke | Booksellers | } \\
\text { Bradford }\end{array}$ \\
\hline 184 & $\begin{array}{l}\text { Brodie, W. (1845). Remarks on the past and present state of New Zealand, } \\
\text { its government, capabilities and prospects... London England: Whittaker } \\
\text { and Co. Copy } 1 . \\
\text { Binding: contemporary embossed cloth, rebacked. }\end{array}$ & $\begin{array}{l}\text { AUCL bequest label, front pastedown: Alfred Kidd. } \\
\text { Accession: } 8165 \text {. }\end{array}$ \\
\hline 186 & $\begin{array}{l}\text { Burford, R. (1838). Description of a view of the Bay of Islands, New Zealand, } \\
\text { and the surrounding country, now exhibiting at the Panorama, Leicester } \\
\text { Square... London: Printed by G. Nichols. } \\
\text { Binding: ca. contemporary half calf and marbled boards. }\end{array}$ & $\begin{array}{l}\text { AUCL bequest label, front pastedown: Alfred Kidd. } \\
\text { Accession: } 8298 . \\
\text { Pencil inscription, verso title page: A Kidd. }\end{array}$ \\
\hline
\end{tabular}




\begin{tabular}{|c|c|c|}
\hline $\begin{array}{l}\text { Record } \\
\text { no. }\end{array}$ & Title details & Provenance evidence (Stage one sampled works from Alfred Kidd's bequest) \\
\hline & & Ink inscription, ca. 19th century, title page: R Luggate \\
\hline 187 & $\begin{array}{l}\text { Chapman, H.S. (1843). The New Zealand portfolio: embracing a series of } \\
\text { papers on subjects of importance to the colonists... London: Smith, Elder. } \\
\text { Binding: contemporary half calf and marbled boards. }\end{array}$ & $\begin{array}{l}\text { AUCL bequest label, front pastedown: Alfred Kidd. } \\
\text { Accession: } 8164 \text {. }\end{array}$ \\
\hline 188 & $\begin{array}{l}\text { Craik, G.L. (1830). The New Zealanders. London: Knight. Copy } 1 . \\
\text { Binding: ca. contemporary half leather and marbled boards. }\end{array}$ & $\begin{array}{l}\text { AUCL bequest label, front pastedown: Alfred Kidd. } \\
\text { Accession: } 8388 \text {. }\end{array}$ \\
\hline 194 & $\begin{array}{l}\text { Cruise, R.A. (1823). Journal of a ten months' residence in New Zealand. } \\
\text { London: Longman, Hurst, Rees, Orme and Brown. Copy } 1 . \\
\text { Binding: 20th century cloth. }\end{array}$ & $\begin{array}{l}\text { AUCL bequest label, front pastedown: Alfred Kidd. } \\
\text { Accession: } 8300 \text {. } \\
\text { Pencil marking, recto frontispiece: } £ 3.10\end{array}$ \\
\hline 197 & $\begin{array}{l}\text { Cruise, R.A. (1824). Journal of a ten months' residence in New Zealand, 2nd } \\
\text { ed. London: Longman, Hurst, Rees, Orme and Brown. Copy } 1 . \\
\text { Binding: contemporary half calf and marbled boards. }\end{array}$ & $\begin{array}{l}\text { AUCL bequest label, front pastedown: Alfred Kidd. } \\
\text { Accession: } 8299 . \\
\text { Ink marking, fly-leaf: F. III. } 24 .\end{array}$ \\
\hline $199-200$ & $\begin{array}{l}\text { Dieffenbach, E. (1843). Travels in New Zealand, with contributions to the } \\
\text { geography, geology, botany, and natural history of that country..., } 2 \text { vols. } \\
\text { London: John Murray. Copy } 1 . \\
\text { Binding: 20th century leather and cloth boards. }\end{array}$ & $\begin{array}{l}\text { UoAL label, fly-leaf: replacement for Kidd bequest label due to Library rebind. } \\
\text { Accession: } 8301-8302 \text {. } \\
\text { Pencil markings, verso title page: } 2201 \text { [?] Pencil: dlf [?] Alf? }\end{array}$ \\
\hline 208 & $\begin{array}{l}\text { Heaphy, C. (1842). Narrative of a residence in various parts of New Zealand: } \\
\text { together with a description of the present state of the Company's } \\
\text { settlements... London: Smith, Elder. Copy } 2 . \\
\text { Binding: half calf and marbled boards, gilt. }\end{array}$ & $\begin{array}{l}\text { AUCL bequest label, front pastedown: Alfred Kidd. } \\
\text { Accession: } 8307 . \\
\text { Pencil marking, contents page: } r \text { [?] 14. } 30 \text { - }\end{array}$ \\
\hline 209 & $\begin{array}{l}\text { Hursthouse, C. (1849). An account of the settlement of New Plymouth, in } \\
\text { New Zealand, from personal observation, during a residence there of five } \\
\text { years... London: Smith, Elder. Copy } 1 . \\
\text { Binding: contemporary cloth, gilt. }\end{array}$ & $\begin{array}{l}\text { AUCL bequest label, front pastedown: Alfred Kidd. } \\
\text { Accession: } 8310 . \\
\text { Pencil marking, verso FFEP: B/ [?] /- }\end{array}$ \\
\hline
\end{tabular}




\begin{tabular}{|c|c|c|}
\hline Record & Title details & Provenance evidence (Stage one sampled works from Alfred Kidd's bequest) \\
\hline & & Binder's label, rear pastedown: Bound by | Westleys \& Co. | Friar Street. | London \\
\hline 213 & $\begin{array}{l}\text { New Zealand Company. West of England Board. (1842). Latest information } \\
\text { from the settlement of New Plymouth, on the coast of Taranake, New } \\
\text { Zealand... London: Smith, Elder and Co. Copy } 2 . \\
\text { Binding: half leather and marbled boards. }\end{array}$ & $\begin{array}{l}\text { AUCL bequest label, front pastedown: Alfred Kidd. } \\
\text { Accession: } 8313 \text {. }\end{array}$ \\
\hline $217-218$ & $\begin{array}{l}\text { Nicholas, J.L. (1817). Narrative of a voyage to New Zealand, performed in } \\
\text { the years } 1814 \text { and } 1815 \text {, in company with the Rev. Samuel Marsden, } \\
\text { Principal Chaplain of New South Wales, } 2 \text { vols. London: Printed for James } \\
\text { Black and Son. Copy } 1 . \\
\text { Binding: 20th century cloth. }\end{array}$ & $\begin{array}{l}\text { Alfred Kidd accession: 8318-19. } \\
\text { Partial stamp, preface, vol. 1-2: Geo. D McVay }\end{array}$ \\
\hline 223 & $\begin{array}{l}\text { Petre, H.W. (1841). An account of the settlements of the New Zealand } \\
\text { Company: from personal observation during a residence there... London: } \\
\text { Smith, Elder and Co. Copy } 2 . \\
\text { Binding: half calf and marbled boards, gilt. }\end{array}$ & $\begin{array}{l}\text { AUCL bequest label, front pastedown: Alfred Kidd. } \\
\text { Accession: } 8166 \text {. }\end{array}$ \\
\hline 225 & $\begin{array}{l}\text { Polack, J.S. (1840). Manners and customs of the New Zealanders: with notes } \\
\text { corroborative of their habits, usages, etc., and remarks to intending } \\
\text { emigrants ..., } 2 \text { vols. bound in } 1 . \text { London: J. Madden. Copy } 1 . \\
\text { Binding: Half leather and marbled boards. }\end{array}$ & $\begin{array}{l}\text { AUCL bequest label, front pastedown: Alfred Kidd. } \\
\text { Accession: } 8323 \text {. }\end{array}$ \\
\hline $232-233$ & $\begin{array}{l}\text { Polack, J.S. (1838). New Zealand: being a narrative of travels and } \\
\text { adventures during a residence in that country between the years } 1831 \text { and } \\
\text { 1837, } 2 \text { vols. London: Bentley. Copy } 1 . \\
\text { Binding: half calf and marbled boards. }\end{array}$ & $\begin{array}{l}\text { UoAL replacement gift label, fly-leaf, vol. 2: Alfred Kidd [Library rebind]. } \\
\text { Accession: 8324-8325. } \\
\text { Pencil annotations, rear pages. }\end{array}$ \\
\hline 239 & $\begin{array}{l}\text { Power, W.T. (1849). Sketches in New Zealand, with pen and pencil: from a } \\
\text { journal kept in that country from July 1846, to June } 1848 . \text { London: } \\
\text { Longman, Brown, Green, and Longmans. Copy } 1 . \\
\text { Binding: } 20^{\text {th }} \text { century quarter leather and cloth boards. }\end{array}$ & $\begin{array}{l}\text { UoAL replacement gift label, verso FFEP: Alfred Kidd [Library rebind]. } \\
\text { Accession: } 8326 . \\
\text { Tipped in to fly-leaf, a printed lending label for Newark Book Society with MSS } \\
\text { showing circulation between } 1849 \text { and } 1851 \text {. }\end{array}$ \\
\hline 244 & $\begin{array}{l}\text { Savage, J. (1807). Some account of New Zealand: particularly the Bay of } \\
\text { Islands and surrounding country; with a description of the religion and } \\
\text { government, language, arts, manufactures, manners, and customs of the } \\
\text { natives, etc. etc. London: Printed for J. Murray. } \\
\text { Binding: } 20^{t} \mathrm{~h} \text { century leather. }\end{array}$ & $\begin{array}{l}\text { Alfred Kidd accession: 8331. [Library rebind]. } \\
\text { Occasional pencil markings, ca. 19th-20th century, to text block. }\end{array}$ \\
\hline
\end{tabular}




\begin{tabular}{|c|c|c|}
\hline $\begin{array}{l}\text { Record } \\
\text { no. }\end{array}$ & Title details & Provenance evidence (Stage one sampled works from Alfred Kidd's bequest) \\
\hline 248 & $\begin{array}{l}\text { Wakefield, E.J. (1848). The hand-book for New Zealand: consisting of the } \\
\text { most recent information compiled for the use of intending colonists / by a } \\
\text { late magistrate of the colony who resided there during four years. London: } \\
\text { Parker. Copy } 1 . \\
\text { Binding: contemporary embossed cloth. }\end{array}$ & $\begin{array}{l}\text { AUCL bequest label, front pastedown: Alfred Kidd. } \\
\text { Accession: } 8400 \text {. } \\
\text { Faint, partly erased pencil calculations, rear pastedown and endpaper. }\end{array}$ \\
\hline 256 & $\begin{array}{l}\text { Yate, W. (1835). An account of New Zealand and of the formation and } \\
\text { progress of the Church Missionary Society's mission in the northern island. } \\
\text { London: Seeley and Burnside. Copy } 2 . \\
\text { Binding: contemporary cloth. }\end{array}$ & $\begin{array}{l}\text { AUCL bequest label, FFEP: Alfred Kidd. } \\
\text { Accession: } 8342 \text {. } \\
\text { Occasional pencil annotations, ca. 20th century, highlighting text. }\end{array}$ \\
\hline 266 & $\begin{array}{l}\text { Wilson, J. (1799). A missionary voyage to the southern Pacific ocean: } \\
\text { performed in the years 1796-1797, 1798, in the ship Duff, commanded by } \\
\text { Captain James Wilson... London: Chapman. Copy } 2 . \\
\text { Binding: 20th century cloth, gilt. }\end{array}$ & $\begin{array}{l}\text { Alfred Kidd accession: } 8402 \text {. } \\
\text { Ink marking, fly-leaf: } £ 3-10\end{array}$ \\
\hline $272-273$ & $\begin{array}{l}\text { Martin, J. (1818). An account of the natives of the Tonga Islands, in the } \\
\text { South Pacific Ocean, with an original grammar and vocabulary of their } \\
\text { language compiled and arranged from the extensive communications of Mr. } \\
\text { William Mariner, several years resident in those islands... } 2 \mathrm{~d} \text { ed., with } \\
\text { additions. London: J. Murray. } 2 \text { vols. } \\
\text { Binding: contemporary paper boards, cloth spine. }\end{array}$ & Alfred Kidd accession: 8248- 8249. \\
\hline 280 & $\begin{array}{l}\text { Keate, G. \& Wilson, H. (1788). An account of the Pelew Islands: situated in } \\
\text { the western part of the Pacific Ocean: composed from the journals and } \\
\text { communications of Captain Henry Wilson, and some of his officers... } \\
\text { London: Printed for Captain Wilson. Copy } 1 . \\
\text { Binding: contemporary full leather, gilt. }\end{array}$ & $\begin{array}{l}\text { AUCL bequest label, front pastedown: Alfred Kidd. } \\
\text { Accession: } 8418 \text {. }\end{array}$ \\
\hline $290-291$ & $\begin{array}{l}\text { Ross, J.C., Sir. (1847). A voyage of discovery and research in the southern } \\
\text { and Antarctic regions, during the years } 1839-43 \ldots, 2 \text { vols. London: John } \\
\text { Murray. } \\
\text { Binding: } 19^{\text {th }} \text { century cloth. }\end{array}$ & $\begin{array}{l}\text { AUCL bequest label, front pastedown, vol. 1-2: Alfred Kidd. } \\
\text { Accession: 8328-8329. } \\
\text { Binder's label, front pastedown, vol. 1-2: Leighton. | Book-binder | \& Account } \\
\text { book | manufacturer. | High St Auckland | Bowring \& Usher. } \\
\text { Fern pressed between rear pastedown and RFEP. }\end{array}$ \\
\hline
\end{tabular}


Appendix 4: Sample two: works with additional provenance evidence

\begin{tabular}{|c|c|c|}
\hline $\begin{array}{l}\text { Record } \\
\text { no. }\end{array}$ & Title details & Works from sample two with additional provenance evidence. \\
\hline 295 & $\begin{array}{l}\text { Mackay, J. (1887). Our dealings with Maori lands, or, comments on } \\
\text { European dealings for the purchase and lease of native lands, and the } \\
\text { legislation thereon. Auckland, N.Z: Kidd \& Wildman. } \\
\text { Bound pamphlets } 0421 .\end{array}$ & $\begin{array}{l}\text { Ink inscription, printed cover: A Kidd Esqr. } \\
\text { Inscription, Alfred Kidd Esqre | With the authors [sic] compliments | James } \\
\text { Mackay. } \\
\text { Accession: } 8128\end{array}$ \\
\hline 305 & $\begin{array}{l}\text { Gudgeon, W.E. (n.d.). Maori migrations to New Zealand. Extract from } \\
\text { Journal of the Polynesian Society. } \\
\text { Bound pamphlets } 0423 .\end{array}$ & $\begin{array}{l}\text { Ink inscription, printer's blank: Mr Kidd | with authors [sic] compliments | W.E. } \\
\text { Gudgeon } \\
\text { Accession: } 8130 .\end{array}$ \\
\hline 382 & $\begin{array}{l}\text { Kilgour, J. (1888). Some observations on the subject of the federation of the } \\
\text { British Empire. Thames, N.Z.: Printed at the Evening Star Office. } \\
\text { Bound pamphlets } 0429 .\end{array}$ & $\begin{array}{l}\text { Ink inscription, title page: A Kidd Esqre | with the Authors [sic] compls. } \\
\text { Accession: } 8136\end{array}$ \\
\hline 390 & $\begin{array}{l}\text { Cuzent, G. (1885). L'archipel des iles de la Société: I'annexion de Taïti à la } \\
\text { France. Brest: Impr. de l'Océan. } \\
\text { Bound pamphlets } 04210 .\end{array}$ & $\begin{array}{l}\text { Bound in with title, a two-page letter and envelope: U.S. Stmr., "Mohican”, | } \\
\text { Auckland, N.Z. | } 20 \text { Aug. '86. | My dear Sir, | I send you herewith the copy of } \\
\text { "Society Groups" by Dr Cuzent, which I | read with great interest and which I } \\
\text { believe | would make an addition to your unique and | valuable little library. | } \\
\text { Very truly Yours | James C. Cresap, | Lieut. |A Kidd | (over) [p. 2] I regret that it is } \\
\text { so poorly bound and hope | you may think it worth a substantial binding. | J.C.C. } \\
\text { Envelope: Mr Kidd Auckland N.Z. } \\
\text { Inscriptions, short title page: James C. Cresap | Lieut. U.S.N. | Papeete, Is. of } \\
\text { Tahiti, | } 27 \text { April, 1886. | U.S. Stmr., "Mohican", | Apia, Upolu Is. (Samoan Group) } \\
\text { | } 19 \text { May } 1886 . \\
\text { Annotations and drawings in Cresap's hand about Tongan and Samoan flags. } \\
\text { Accession: } 8137 .\end{array}$ \\
\hline 397 & $\begin{array}{l}\text { Woolls, W. (1844). A short account of the character and labours of the Rev. } \\
\text { Samuel Marsden, formerly Principal Chaplain of the Church of England, in } \\
\text { New South Wales: written for the express purpose of raising funds towards } \\
\text { the erection of a church in the Parish of Marsfield, Parramatta. Parramatta }\end{array}$ & $\begin{array}{l}\text { Bound in with title, an MSS from R. Coupland Harding to Mr. W. Wildman, dated } \\
14 \text { April 1890, re. return of the title and commentary on early printers in New } \\
\text { Zealand. }\end{array}$ \\
\hline
\end{tabular}




\begin{tabular}{|c|c|c|}
\hline Record & Title details & Works from sample two with additional provenance evidence. \\
\hline & $\begin{array}{l}\text { [N.S.W.]: B. Isaacs. } \\
\text { Bound pamphlets } 04212 .\end{array}$ & Accession: 8139. \\
\hline 444 & $\begin{array}{l}\text { Wohlers, J.F.H. (1895). Memories of the life of J.F.H. Wohlers: missionary at } \\
\text { Ruapuke, New Zealand: an autobiography / translated from the German by } \\
\text { John Houghton. Dunedin N.Z.: Otago Daily Times \& Witness Newspapers. } \\
\text { Binding: 20th century cloth. }\end{array}$ & $\begin{array}{l}\text { UoAL replacement label, verso FFEP: Mr. Alfred Kidd. } \\
\text { Accession: } 8158 . \\
\text { MSS sheet bound in: "Alfred Kidd Esq I With the translator's very kind regards | } \\
\text { Auckland Septr 10th / 96." } \\
\text { Ink inscription, recto frontispiece, in same hand: "With the most respectful } \\
\text { compliments of the translator who has read lan Maclaren's work with the keenest } \\
\text { enjoyment. Dunedin N.Z. Apr ? ...? 96. | The Revd John Watson Liverpool. }\end{array}$ \\
\hline $445-446$ & $\begin{array}{l}\text { Tucker, H.W. (1879). Memoir of the life and episcopate of George Augustus } \\
\text { Selwyn, D.D., Bishop of New Zealand, 1841-1869, Bishop of Lichfield, 1867- } \\
\text { 1878..., } 2 \text { vols. London England: William Wells Gardner. Copy } 1 . \\
\text { Binding: contemporary cloth. }\end{array}$ & $\begin{array}{l}\text { UoA replacement bequest label, FFEP, vol. 1, short title page, vol. 2: Alfred Kidd. } \\
\text { Ink stamp, vol. 1, twice on short title page: Alfred Kidd } \\
\text { Ink inscription, short title page, vol. 1: No } 24 \\
\text { Ink stamp, vol. 2, twice on short title page: Alfred Kidd } \\
\text { Ink inscription, short title page, vol. 2: No } 25 \\
\text { Accession: } 8159-8160 \text {. }\end{array}$ \\
\hline 451 & $\begin{array}{l}\text { Matthew, P. (1839). Emigration fields: North America, The Cape, Australia } \\
\text { and New Zealand: describing these countries, and giving a comparative } \\
\text { view of the advantages they present to British settlers. Edinburgh: A. \& C. } \\
\text { Black; London: Longman, Orme, Brown, Green and Longmans. } \\
\text { Binding: 20th century cloth. }\end{array}$ & $\begin{array}{l}\text { Ink inscription, title page: Charles Civart [?] | May } 1839 \\
\text { Accession: } 8169 .\end{array}$ \\
\hline 455 & $\begin{array}{l}\text { Tregear, E. (1891). The Maori-Polynesian comparative dictionary. } \\
\text { Wellington: Lyon and Blair. } \\
\text { Binding: contemporary cloth. }\end{array}$ & $\begin{array}{l}\text { AUCL bequest label, front pastedown: Alfred Kidd. } \\
\text { Ink inscription, verso short title page: A Kidd [Gn?] | from T Lawry. } \\
\text { Accession: } 8185\end{array}$ \\
\hline 456 & $\begin{array}{l}\text { (1882-1883). The New Zealand journal of science devoted to the } \\
\text { furtherance of natural and applied science throughout the colony, vol. } 1 . \\
\text { Dunedin, N.Z.: J. Wilkie. }\end{array}$ & $\begin{array}{l}\text { AUCL bequest label, front pastedown: Alfred Kidd. } \\
\text { Binder's ticket, front pastedown: Leighton }\end{array}$ \\
\hline
\end{tabular}




\begin{tabular}{|c|c|c|}
\hline & Title details & Works from sample two with additional provenance evidence. \\
\hline & Binding: ca. $20^{\text {th }}$ century half leather and cloth boards. & Accession: 8186. \\
\hline 458 & $\begin{array}{l}\text { Bennett, G. (1860). Gatherings of a naturalist in Australasia. London: John } \\
\text { van Voorst. } \\
\text { Binding: contemporary cloth. }\end{array}$ & $\begin{array}{l}\text { AUCL bequest label, FFEP: Alfred Kidd. } \\
\text { Ink inscription, title page: D Douglas. } \\
\text { Accession: } 8194 \text {. }\end{array}$ \\
\hline $462-463$ & $\begin{array}{l}\text { Ellis, W. (1829). Polynesian researches: during a residence of nearly six } \\
\text { years in the South Sea Islands..., } 2 \text { vols. London: Fisher, Son \& Jackson. Copy } \\
1 . \\
\text { Binding: ca. } 19^{\text {th }} \text { century full leather. }\end{array}$ & $\begin{array}{l}\text { AUCL bequest label, recto fly-leaf, vol. 1-2: Alfred Kidd. } \\
\text { Accession: } 8246-8247 . \\
\text { Armorial bookplate, verso FFEP, vol. 1-2: William Hale. } \\
\text { Annotation to flyleaf, vol. 1, about death of the author. }\end{array}$ \\
\hline $466-467$ & $\begin{array}{l}\text { Buller, W.L., Sir. (1888). History of the Birds of New Zealand, 2nd ed, } 2 \text { vols. } \\
\text { London England: The Author for the subscribers. Copy } 1 . \\
\text { Binding: contemporary quarter leather and cloth boards. }\end{array}$ & $\begin{array}{l}\text { AUCL bequest label, front pastedown, vol. 1-2: Alfred Kidd. } \\
\text { Accession: 8406-8407. } \\
\text { Ink inscription, verso FFEP vol. 1: W.L. Buller May } 1892 .\end{array}$ \\
\hline $473-474$ & $\begin{array}{l}\text { MacGillivray. (1852). Narrative of the voyage of H.M.S. Rattlesnake, } \\
\text { commanded by the late Captain Owen Stanley, } 2 \text { vols. London: T. \& W. } \\
\text { Boone. } \\
\text { Binding: contemporary cloth. }\end{array}$ & $\begin{array}{l}\text { AUCL bequest label, front pastedown, vol. 1-2: Alfred Kidd. } \\
\text { Accession: 8255-8256. } \\
\text { Blind stamp, FFEP, vol.1-2: Edward T. Whitefield | } 178 \text { Strand I London. } \\
\text { Newspaper clipping tipped in, Vol. 1, headed "The commencement of the author's } \\
\text { career" and ink annotation: "Taken from "Herald” July 6/89 Biography of Professor } \\
\text { Huxley - Born May 4th } 1825 \text { @ Ealing". }\end{array}$ \\
\hline $481-482$ & $\begin{array}{l}\text { Baden-Powell, G. (1872). New homes for the old country: a personal } \\
\text { experience of the political and domestic life, the industries, and the natural } \\
\text { history of Australia and New Zealand, } 2 \text { vols. London: R. Bentley. } \\
\text { Binding: contemporary cloth. }\end{array}$ & $\begin{array}{l}\text { AUCL bequest label, front pastedown, vol. 1-2: Alfred Kidd. } \\
\text { Accession: } 8264-8265 \text {. } \\
\text { Auckland Circulating Library labels pasted to front boards, vol 1-2, with MSS: 493; }\end{array}$ \\
\hline
\end{tabular}




\begin{tabular}{|c|c|c|}
\hline Record & Title details & Works from sample two with additional provenance evidence. \\
\hline & & MSS: 494. \\
\hline 500 & $\begin{array}{l}\text { Shortland, E. (1851). The southern districts of New Zealand: a journal, with } \\
\text { passing notices of the customs of the aborigines. London England: } \\
\text { Longman, Brown, Green, \& Longmans. Copy } 1 . \\
\text { Binding: contemporary cloth. }\end{array}$ & $\begin{array}{l}\text { AUCL bequest label, front pastedown: Alfred Kidd. } \\
\text { Accession: } 8332 . \\
\text { Binder's ticket, rear pastedown: Westleys \& [obscured] | Friar St [obscured] | } \\
\text { London. }\end{array}$ \\
\hline 503 & $\begin{array}{l}\text { Thomas, J. (1886). Cannibals \& convicts: notes of personal experiences in } \\
\text { the Western Pacific. London: Cassell. } \\
\text { Binding: contemporary quarter leather and cloth boards, rebacked. }\end{array}$ & $\begin{array}{l}\text { AUCL bequest label, front pastedown: Alfred Kidd. } \\
\text { Accession: } 8254 . \\
\text { Ink inscription, title page: Alfred Kidd | a souvenir of | "The Vagabond". }\end{array}$ \\
\hline $508-509$ & $\begin{array}{l}\text { Lang, J.D. (1837) An historical and statistical account of New South Wales: } \\
\text { both as a penal settlement and as a British colony, } 2 \text { vols. London: A.J. } \\
\text { Valpy. } \\
\text { Binding: contemporary paper boards. }\end{array}$ & $\begin{array}{l}\text { Accession: 8351-8352. } \\
\text { Bookseller's label, front pastedown, vol. 1: Bain, | Bookseller, | } 1 \text { Haymarket. } \\
\text { Illegible ink inscription, title page, vol. 2, dated } 1837 .\end{array}$ \\
\hline 517 & $\begin{array}{l}\text { Barton, G.B. (1866). Literature in New South Wales, Sydney, T. Richards, } \\
\text { govt. printer. } \\
\text { Binding: contemporary cloth. }\end{array}$ & $\begin{array}{l}\text { AUCL bequest label, front pastedown: Alfred Kidd. } \\
\text { Accession: } 8126 . \\
\text { Ink inscription, title page: Mr. Alfred Kidd | from R.A.A Sherrin | 6.9. 1891. | } \\
\text { Auckland. }\end{array}$ \\
\hline
\end{tabular}




\section{References}

Adams, T. R., \& Barker, N. (1993). A new model for the study of the book. In N. Barker (Ed.), A potencie of life: books in society: The Clark Lectures 1986-1987 (pp. 5-43). London: British Library.

Advertisements. (1878, October 4). New Zealand Herald, p. 1. Retrieved from PapersPast.

Advertisements. (1886, December 21). New Zealand Herald, p. 4. Retrieved from PapersPast.

Advertisements. (1898, July 12). Auckland Star, p. 1. Retrieved from PapersPast.

Andersen, J. (1936). The lure of New Zealand book collecting. Auckland: Whitcombe and Tombs.

Arrival of the U.S. corvette Mohican. (1886, August 16). Auckland Star, p. 2. Retrieved from PapersPast.

Association of College and Research Libraries Rare Books and Manuscripts Section. (n.d.). RBMS controlled vocabularies: provenance evidence terms. Retrieved October 19, 2013, from http://www.rbms.info/committees/bibliographic standards/controlled vocabularies/prove nance/alphabetical list.htm

The Auckland free public library and art gallery. (1885, June 20). Auckland Star, p. 6. Retrieved from PapersPast.

Auckland University College. (1919). Auckland University College Calendar for the year 1919. Auckland: The College.

Auckland University College Council. (1902, August 19). [Council minutes. Letter from Mr Maxwell Walker]. Council minutes, January 1899-December 1904. Archive, Vice-Chancellor's Office, University of Auckland, Auckland.

Auckland University College Council. (1918, September 16). [Council minutes. Bequest from the late Mr A. Kidd]. Council minutes, March 1917- Feb 1920. Archive, Vice-Chancellor's Office, University of Auckland, Auckland.

Australian Subscription Library. (1830). Catalogue, with rules, regulations and bye-laws for the conduct of the Australian Subscription Library, and reading room. Retrieved from http://handle.slv.vic.gov.au/10381/110985

Barker, N., \& Carter, J. (2010). ABC for book collectors (8th ed.). New Castle, Del.: Oak Knoll Books.

Barrowman, R. (1995). The Turnbull: a library and its world. Auckland: Auckland University Press, Historical Branch, Department of Internal Affairs. 
Beu, A. G. (1996). 'Suter, Henry', from The Dictionary of New Zealand Biography Te Ara - the Encyclopedia of New Zealand. Updated 26-Feb-2014. Retrieved from http://www.TeAra.govt.nz/en/biographies/3s40/suter-henry

Black, A. (2006). Information history. Annual Review of Information Science and Technology, 40(1), 441-473. doi: 10.1002/aris.1440400118

Brett, H. (1888). Brett's Auckland almanac: provincial handbook and strangers' vade mecum for 1888. Auckland: H. Brett

Buller, W. L., Sir. (1888). A history of the birds of New Zealand (2nd ed.). London: The Author for the subscribers.

Bush, G. W. A. (1971). Decently and in order: the government of the city of Auckland 1840-1971: the centennial history of the Auckland City Council. Auckland: Published for the Auckland City Council by Collins.

Chadwick, J. (1906). Men of mark in the world of sport in New Zealand. Auckland: The Brett Printing and Publishing Co.

The College Library. (1925, November 17). Auckland Star, p. 6. Retrieved from PapersPast.

Cresap, J. C. (1886, August 20). [Letter to Alfred Kidd]. Bound in with New Zealand Glass Case Pamphlets 042 10. Special Collections, University of Auckland Libraries and Learning Services, Auckland.

Cullingford, A. (2011). The special collections handbook. London: Facet Publishing.

Customs character \& countries. (1911, December 18). The Observer, p. 12. Retrieved from PapersPast.

Death of George Bennet, Esq. (1842, January 1). Missionary Magazine and Chronicle, p. 14. Retrieved from 19th Century UK Periodicals.

Death of Mr. W. Wildman. (1897, August 3). New Zealand Herald, p. 5. Retrieved from PapersPast.

Death of Mrs E.A. Kidd. (1947, November 8). New Zealand Herald, p. 10. Retrieved from PapersPast.

Death of Mrs. Alfred Kidd. (1904, November 28). Auckland Star, p. 3. Retrieved from PapersPast.

Deaths. (1912, April 8). Auckland Star, p. 10. Retrieved from PapersPast.

Ellerslie land syndicate. (1888, July 19). New Zealand Herald, p. 5. Retrieved from PapersPast. 
Elliott, V. G. (1982). Early printed books in New Zealand: some thoughts on the origins of institutional collections. Bulletin (Bibliographical Society of Australia and New Zealand), 6(4), 175-184.

English impressions of the Tarawera Eruption. (1886, September 13). Auckland Star, p. 2. Retrieved from PapersPast.

Gorman, G. E., \& Clayton, P. (2005). Qualitative research for the information professional: a practical handbook (2nd ed.). London: Facet Publishing.

Gunson, N. (1966). 'Henry, William (1770-1859)'. Australian Dictionary of Biography, National Centre of Biography, Australian National University. Retrieved from http://adb.anu.edu.au/biography/henry-william-2236/text2297, published in hardcopy 1966, accessed online 27 May 2014.

Gunson, N. (1970). The deviations of a missionary family: The Henrys of Tahiti. In J. W. Davidson \& D. Scarr (Eds.), Pacific Islands portraits. Wellington, N.Z.: A.H. \& A.W. Reed.

Hordern House. (2005). The Parsons collection: Rare Pacific voyage books from the collection of David Parsons. (Vol. 1). Potts Point, N.S.W.: Hordern House.

Howsam, L. (2006). Old books and new histories: an orientation to studies in book and print culture. Buffalo, Toronto: University of Toronto Press.

Hughes, M. A. (2013). Books as social currency: Robert Coupland Harding and the field of book collecting in New Zealand 1880-1920. (Unpublished Master of Arts thesis, Victoria University of Wellington). Retrieved from ResearchArchive@Victoria e-Thesis.

Internal Affairs; New Zealand Government. (1875-1983). Births, deaths and marriages online. Retrieved May 2, 2014 https://www.bdmhistoricalrecords.dia.govt.nz/Home/

James R. Lawson Pty. (1897). Important sale by auction, without any reserve, at Lawson \& Smith's auction rooms, 128-132 Pitt Street (near King Street) under instructions from Messrs. Angus \& Robertson, the duplicate copies of rare books recently purchased from Public Library of New South Wales... Sydney: Websdale, Shoosmith \& Co.

Johnson, O. A. (1962, April). Acquisitions in the University library. University of Auckland Gazette, $4(1), 8-9$.

Johnson, O. A. (1988). The true university: a short history of the University of Auckland Library 18831986. Auckland: University of Auckland Library.

Jones, C., \& Matthews, B. (Eds.). (2011). Treasures of the University of Canterbury Library. Christchurch: Canterbury University Press.

Kerr, D. (2002). Frank W. Reed and his Dumas collection: Portrait of a bibliophile. Auckland, N.Z.: Auckland Library Heritage Trust. 
Kerr, D. (2006). Amassing treasures for all times: Sir George Grey, colonial bookman and collector. Dunedin, N.Z.: Otago University Press.

Kidd, A. (1891, October 7). [Letter to Thomas Cheeseman]. Auckland Museum Correspondence General Correspondence K - Little Barrier Island, 1868-1899, MA 95/38/6, folder 4. Auckland War Memorial Museum Library, Auckland.

Kidd, A. (1906, October 26). [Letter to Sir George Fowlds]. Sir George Fowlds papers. MSS \& Archives A-17, 2/19. Special Collections, University of Auckland Libraries and Learning Services, Auckland.

Kidd and Wildman. (1887, November 28). [Memorandum to Sir John Hall]. Hall, John (Sir), 18241907: Papers. MS-Group-0033: MS-Copy-Micro-0694-42. Alexander Turnbull Library, Wellington.

Leedy, P. D., \& Ormrod, J. E. (2013). Practical research: planning and design (International edition; 10th ed.). Boston, MA,: Pearson Education.

Lightbourne, R. (2000). The Mangaroa Collection: discovering a forgotten heritage, Vol. 1 \& Appendix. (Unpublished MLIS research project, Victoria University of Wellington, 2000). Retrieved from Victoria University of Wellington Restricted Archive.

Local and general news. (1917, August 29). New Zealand Herald, p. 6. Retrieved from PapersPast.

Lundy, M. W. (2008). Provenance evidence in bibliographic records. Library Resources \& Technical Services, 52(3), 164-172. Retrieved from EBSCOhost database.

Major, K. H. (2000). The Henry Wright book collection: The institutionalisation of a private library. (Unpublished MLIS research project, Victoria University of Wellington, 2000). Retrieved from Victoria University of Wellington Restricted Archive.

Marriage. (1874, May 7). Auckland Star, p. 2. Retrieved from PapersPast.

Martin, J. E. (2008). Parliament's library, 150 years. Wellington, N.Z.: Steele Roberts.

Maxted, I. (2007, February 28). Exeter Working Papers in British Book Trade History; The Devon book trades: a biographical dictionary. Plymouth. Surnames: L-R. Retrieved April 25, 2014 from http://bookhistory.blogspot.co.nz/2006/12/devon-plymouth-l-r.html

Maxted, I. (2012, July 15). The London book trades 1775-1800: a preliminary checklist of members. Names C. Retrieved April 24, 2014, from http://bookhistory.blogspot.co.nz/2007/01/london-1775-1800-c.html

McCormick, E. H. (1961). The fascinating folly: Dr. Hocken and his fellow collectors. Dunedin: University of Otago Press. 
McCormick, E. H. (1974). Alexander Turnbull: his life, his circle, his collections. Wellington: Alexander Turnbull Library.

McEldowney, D. (2000). 'McCormick, Eric Hall', from The Dictionary of New Zealand Biography. Te Ara - the Encyclopedia of New Zealand, updated November 13, 2013. Retrieved from http://www.TeAra.govt.nz/en/biographies/5m8/mccormick-eric-hall

Men of the Time. (1887, April 2). Observer, p. 17. Retrieved from PapersPast.

Minchin, A. (1941, October). Auckland University College Library. New Zealand Libraries, 5, 52-57.

Mogford, J. C. (1990). 'Whisker, Alexander', from The Dictionary of New Zealand Biography. Te Arathe Encyclopedia of New Zealand, updated April 2, 2014. Retrieved from http://www.TeAra.govt.nz/en/biographies/1w16/whisker-alexander

Morley, J. (1968). Newark Book Society, 1777-1872. Library \& Information History, 1(3), 77-86.

Mr Alfred Kidd. (1902, November 26 ). Auckland Star, p. 3. Retrieved from PapersPast.

Mr Alfred Kidd before the electors. (1902, November 22). The Observer, p. 10. Retrieved from PapersPast.

Mr. A. Kidd's bankruptcy annulled. (1889, May 18). New Zealand Herald, p. 5. Retrieved from PapersPast.

Mr. Alfred Kidd. (1901, August 1). New Zealand Illustrated Magazine, p. 815. Retrieved from PapersPast.

New Zealand Institute. (1884-1909, 1916). Transactions and proceedings of the New Zealand Institute, 17-49.

New Zealand Institute. (1906). Auckland Institute ordinary members. Transactions and proceedings of the New Zealand Institute, 39, 558-560.

New Zealand Institute. (1916). Auckland Institute. Transactions and proceedings of the New Zealand Institute, 49, 552-556.

New Zealand literature and records. (1886, December 27). New Zealand Herald, p. 3. Retrieved from PapersPast.

New Zealand Parliament. (1917, 7 August - 7 September). Parliamentary debates (Hansard) / House of Representatives. Vol. 179: Wellington, N.Z.: Govt. Printer.

Nightingale, T. (1996). 'Vaile, Edward Earle', from The Dictionary of New Zealand Biography. Te Ara the Encyclopedia of New Zealand, updated March 19, 2014. Retrieved from http://www.TeAra.govt.nz/en/biographies/3v1/vaile-edward-earle 
Obituary. (1917, August 25). Auckland Star, p. 6. Retrieved from Papers Past.

Obituary, Mr. F.J. Halse (1936, 30 April). Evening Post, p. 10. Retrieved from PapersPast.

Online Computer Library Center. (2013). Dewey Decimal Classification summaries. Retrieved

October 19, 2013, from http://www.oclc.org/dewey/resources/summaries.en.htm|\#900

Overmier, J. A., \& Doak, E. M. (1996). Provenance records in Rare Book and Special Collections. Rare Books \& Manuscripts Librarianship, 11(2), 91-99. Retrieved from http://rbm.acrl.org/content/rbml/11/2/91.short

Oxford English Dictionary Online. (2013). "Rare book." Retrieved August 15, 2013, from http://oed.com

Pars about people. (1896, July 18). The Observer, p. 18. Retrieved from PapersPast.

Pearson, D. (1994). Provenance research in book history: a handbook. London: The British Library.

Pearson, D. (2008). Books as history: the importance of books beyond their texts. London: British Library; New Castle, Del.: Oak Knoll Press.

Pearson, D. (2009). Introduction: From texts to collections. In G. Mandelbrote \& B. Taylor (Eds.), Libraries within the library: the origins of the British Library's printed collections (pp. 1-7). London: The British Library.

Pearson, D. (2013). Foxcroft Lecture, State Library of Victoria: David Pearson on libraries as history. Retrieved October 10, 2013, from http://www.slv.vic.gov.au/audio-video/david-pearsonlibraries-as-history

Perry, Nancye Enid Kent (1918-2011). Australian Women's Register. Retrieved from http://www.womenaustralia.info/biogs/AWE1142b.htm

Personal notes from London. (1912a, April 10). Auckland Star, p. 11. Retrieved from PapersPast.

Personal notes from London. (1912b, April 12). The Press, p. 3. Retrieved from PapersPast.

Petherick, E. A. (1886). Catalogue of the York Gate library formed by Mr. S. William Silver ... (2nd ed.). London: John Murray.

Polynesian Society. (1927). Ordinary members. Journal of the Polynesian Society, 36(141), 90-96.

Presentation to Mr. and Mrs. Alfred Kidd. (1903, June 3). New Zealand Herald, p. 6. Retrieved from PapersPast.

Registrar of births deaths and marriages. (1917). Kidd, Alfred - 1917/2888, certificate of death. Deaths in the district of Auckland during the quarter ending the 30 of September 1917. 
Ross, J. (1997). Book buying and collectors. In P. Griffith, R. Harvey \& K. Maslen (Eds.), Book \& print in New Zealand: A guide to print culture in Aotearoa (pp. 197-211). Wellington: Victoria University Press.

Rukavina, A. (2010). The development of the international book trade, 1870-1895: Tangled networks. Houndmills, Basingstoke, Hampshire; New York, NY: Palgrave Macmillan.

Scholefield, G. H. (1908). Who's who in New Zealand and the western Pacific. Wellington: Gordon \& Gotch.

Sinclair, K., \& McNaughton, T. (1983). A history of the University of Auckland, 1883-1983. Auckland: Auckland University Press: Oxford University Press.

Sir George Grey. (1886, March 16). New Zealand Herald, p. 6. Retrieved from PapersPast.

Society for the History of Authorship Readership and Publishing. (2013). Book history. Retrieved August, 12, 2013, from http://www.sharpweb.org/book-history-en

Stanton, J. (1918, September 9). [Letter to Auckland University Council]. Incoming correspondence, 1 September-16 October 1918. Records of the Registrar, Auckland University College, Auckland.

State Library New South Wales. (2013, November 19). History of the library. Retrieved April 24, 2014, from http://www.sl.nsw.gov.au/about/history/

Suter, H. (1913). Manual of the New Zealand mollusca: With an atlas of quarto plates. Wellington: Govt. Printer.

Tee, G. (1980/81). Charles Darwin's correspondents in New Zealand. Proceedings of the Australasian Association for the history, philosophy and social studies of science, 12(2), 367-379.

The University of Auckland Library. (1919). [Accession register]. University of Auckland Library. History series. MSS \& Archives E-10, item 2.1.1. Special Collections, University of Auckland Libraries and Learning Services, Auckland.

The University of Auckland Library. (1966). Report of the Librarian for the year 1965. Auckland: The University of Auckland Library.

The University of Auckland Library. (1968). University of Auckland Library newsletter. Auckland: The University of Auckland Library.

To the editor of the New Zealand Journal. (1841, March 27). New Zealand Journal, pp. 73-84.

Topics of the week. (1894, June 30). The New Zealand Graphic and Ladies' Journal, p. 603. Retrieved from 19th Century UK Periodicals. 
Trade topics. (1897, March 11). Sporting Review and Licensed Victuallers Gazette, p. 11.

Traue, J. E. (1991). For the ultimate good of the nation: The contribution of New Zealand's first book collectors. Committed to print: Selected essays in praise of the common culture of the book (pp. 28-42). Wellington: Victoria University Press.

Trembath, K. A. (1969). Ad Augusta a centennial history of Auckland Grammar School, 1869-1969. Auckland: Auckland Grammar School Old Boys' Association.

An unfortunate speculation. (1888, July 13). New Zealand Herald, p. 3. Retrieved from PapersPast.

Untitled. (1876, September 2). Auckland Star, p. 2. Retrieved from PapersPast.

Untitled. (1877, October 2). Waikato Times, p. 2. Retrieved from PapersPast.

Untitled. (1887a, April 5). New Zealand Herald, p. 4. Retrieved from PapersPast.

Untitled. (1887b, October 29). Auckland Star, p. 4. Retrieved from PapersPast.

Untitled. (1890, January 18). New Zealand Herald, p. 4. Retrieved from PapersPast.

Waite, P. (2013). A heritage betrayed. Prospect: the journal of the Epsom \& Eden District Historical Society Inc., 12, 2-20.

Wevers, L. (2010). Reading on the farm: Victorian fiction and the colonial world. Wellington, New Zealand: Victoria University Press.

Wildman and Lyell. (1902) The Cyclopedia of New Zealand: industrial, descriptive, historical, biographical facts, figures, illustrations. [Auckland Provincial District]. (Vol. 2). Christchurch: The Cyclopedia Company Limited.

Wildman, W. (1889, October 10). [Invoice to Sir George Grey]. Grey New Zealand letters, GNZ MSS 258. Sir George Grey Special Collections, Auckland Libraries, Auckland. 